\title{
WestVirginiaUniversity
}

THE RESEARCH REPOSITORY @ WVU

Graduate Theses, Dissertations, and Problem Reports

1999

\section{School improvement councils as change agents}

Thurman Jeffrey Fry

West Virginia University

Follow this and additional works at: https://researchrepository.wvu.edu/etd

\section{Recommended Citation}

Fry, Thurman Jeffrey, "School improvement councils as change agents" (1999). Graduate Theses, Dissertations, and Problem Reports. 3129.

https://researchrepository.wvu.edu/etd/3129

This Dissertation is protected by copyright and/or related rights. It has been brought to you by the The Research Repository @ WVU with permission from the rights-holder(s). You are free to use this Dissertation in any way that is permitted by the copyright and related rights legislation that applies to your use. For other uses you must obtain permission from the rights-holder(s) directly, unless additional rights are indicated by a Creative Commons license in the record and/ or on the work itself. This Dissertation has been accepted for inclusion in WVU Graduate Theses, Dissertations, and Problem Reports collection by an authorized administrator of The Research Repository @ WVU.

For more information, please contact researchrepository@mail.wvu.edu. 


\title{
School Improvement Councils As Change Agents
}

\author{
Thurman Jeffrey Fry
Dissertation submitted to the College of Human Resources and Education at West Virginia University
for the degree of \\ in partial fulfillment of the requirements
}

Doctor of Education

in

Educational Leadership
Phyllis C. Durden, Ed.D., Chair
Martha D. Dean, Ed.D.
Ernest R. Goeres, Ph.D.
Perry D. Phillips, Ed.D.
Floyd L. Stead, Ed.D.

\section{Morgantown, West Virginia \\ 1999}

Keywords: School Improvement Councils, Change Agents, Site-Based Management, Local Control

Copyright 1999 Thurman Jeffrey Fry 


\section{ABSTRACT \\ School Improvement Councils As Change Agents}

Thurman Jeffrey Fry

The purpose of this study was to explore the perceptions of school improvement council members of 1999, and compare them to a similar study performed in 1994. This study reflected the speed at which LSIC's are becoming reform agents. A questionnaire was used with a stratified random sampling based on student enrollment. Chi square analysis, standard deviations, means, and percentages were used to identify and compare the data. The questions researched were:

1. What activities do the school improvement council members feel are worthwhile?

2. How involved are SIC's in local decision-making?

3. How have the activities of the SIC contributed to improving their schools?

4. What are the most frequently listed contributions made by SIC's?

5. What do SIC members perceive as problems hindering their effectiveness?

6. Do demographic factors influence SIC activities?

7. How do the results of this survey differ from a similar one completed in 1994 ?

Findings Included:

1. SIC's encourage parental involvement about the same as 1994.

2. Parents and students have more decision-making input than before.

3. The most frequently reported SIC activities remain encouragement of school volunteer programs and after hours community use of school facilities.

4. Results indicated an increase in the development of mentorship programs.

5. SIC's continue to mostly ignore applying for or obtaining waivers.

6. Facility/safety improvements continue to be the major accomplishment listed by SIC's but student oriented programs was listed second.

7. Group harmony continues to be the major strength listed by SIC members.

8. Lack of interest continues to be the major weakness listed by SIC members.

9. A sizeable increase was reflected in applications for "School of 
Excellence" awards.

School improvement council members are still in dire need of training. Though their attention was mainly focused on facility improvements, this study revealed a beginning emphasis towards student oriented programs. Efforts at school reform through site-based management reflected some improvement for parents and students being involved in the decision-making process. Service personnel exhibited a minor increase in decision-making opportunities but exhibited a significant increase in improved performance. 


\section{Acknowledgments}

I would like to acknowledge those who assisted me in the completion of my doctoral program and dissertation. My dissertation committee was comprised of very exceptional people. My chair, Dr. Phyllis Durden, not only provided leadership during my dissertation, but also through all of the class work required in the doctoral program. Dr. Perry Phillips continued to provide insight and assistance after suffering a heart attack. Dr. Ernest Goeres insured all the rules and regulations were followed and proper documentation completed. Dr. Martha Dean, a West Virginia Superintendent of the Year winner, provided assistance and allowed me the use of her materials and study as a base line. Dr. Larry Stead provided guidance whenever I requested and gave me the courage to finish this program. I am very impressed with his style.

Others who have assisted me in my pursuit of a doctorate in education include my family. My wife, Lois, my son, Jason, and my daughter, Melissa, gave freely their time and financial sacrifices for me to complete this program. To them, I will be eternally grateful. My father and mother, Thurman and Kathleen Fry, always encouraged me to do my very best and to always set lofty goals. What a wonderful childhood they provided for me. Their confidence and guidance allowed me to develop the traits needed to be an honorable and successful person. 
That influence has sustained me through the doctoral program.

I also want to thank my cohorts for being there when the times got rough. Their encouragement and caring truly removed some of the stress that arose during the program. I consider it an honor to be in the same cohort class comprised of these highly successful individuals. I will always remember them.

Finally, I would like to thank Dean William Deaton for standing up for all that is right when it may not be the easiest thing to do. West Virginia University is very fortunate to have a man of his caliber. 


\section{TABLE OF CONTENTS}

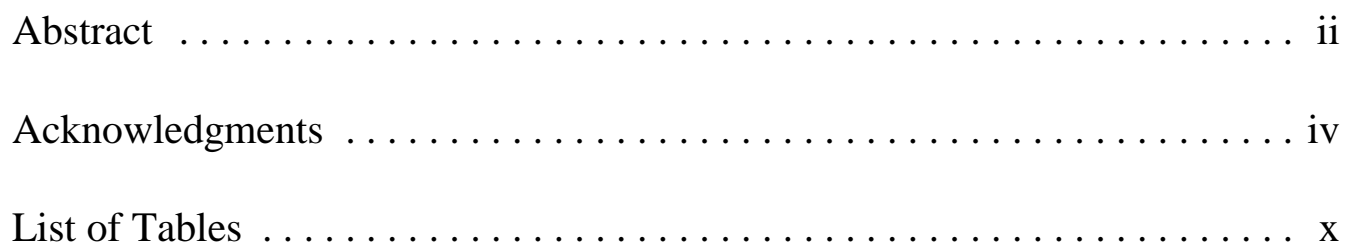

Chapter Page

I. INTRODUCTION $\ldots \ldots \ldots \ldots \ldots \ldots \ldots \ldots \ldots \ldots$

Purpose of the Study $\ldots \ldots \ldots \ldots \ldots \ldots \ldots \ldots$

Statement of the Problem ............... 4

Justification of the Study $\ldots \ldots \ldots \ldots \ldots \ldots \ldots$

Research Questions $\ldots \ldots \ldots \ldots \ldots \ldots \ldots$

Limitations $\ldots \ldots \ldots \ldots \ldots \ldots \ldots \ldots \ldots$

Definitions $\ldots \ldots \ldots \ldots \ldots \ldots \ldots \ldots \ldots \ldots$

II. REVIEW OF THE LITERATURE . . . . . . . . . . 11

Educational Trends $\ldots \ldots \ldots \ldots \ldots \ldots \ldots \ldots \ldots$

Educational Changes $\ldots \ldots \ldots \ldots \ldots \ldots \ldots$

Legislated Educational Reform . . . . . . . . . . . 19

Site-Based Decision-Making $\ldots \ldots \ldots \ldots \ldots \ldots \ldots$ 


\section{TABLE OF CONTENTS}

Page

School Site Councils ................... 25

Benefits and Limitations of School-Based

Decision-Making ............... 26

Components of Successful School-Based Councils ........................ 29

West Virginia School Reform Legislation . . . . . . . . . 33

III METHODOLOGY ..................... 37

Introduction $\ldots \ldots \ldots \ldots \ldots \ldots \ldots \ldots \ldots \ldots \ldots \ldots$

Sampling Procedures $\ldots \ldots \ldots \ldots \ldots \ldots \ldots \ldots$

Distribution of Surveys $\ldots \ldots \ldots \ldots \ldots \ldots$

Survey Instrument and Internal Validity $\ldots \ldots \ldots \ldots \ldots$

Data Analysis ....................... 39

IV SURVEY RESULTS $\ldots \ldots \ldots \ldots \ldots \ldots \ldots \ldots \ldots \ldots \ldots$

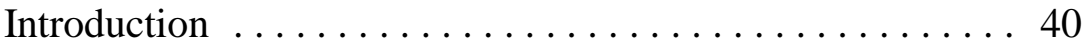

Description of Respondents . . . . . . . . . . . . 40

Demographic Information Collected $\ldots \ldots \ldots \ldots \ldots$. . . 42 


\section{TABLE OF CONTENTS}

Page

The Work of School Improvement Councils . . . . . . . . . 47

School Improvement Council's Work Defined by

Respondent's Perceptions ............. 97

Respondent's Perceptions of Changes Produced by

School Improvement Councils . . . . . . . . . . . . . 101

V SUMMARIES AND RECOMMENDATIONS . . . . . . . . . . . 132

Introduction $\ldots \ldots \ldots \ldots \ldots \ldots \ldots \ldots \ldots \ldots \ldots \ldots \ldots \ldots \ldots$

Justification of the Study . . . . . . . . . . . . 133

Problem Statement . . . . . . . . . . . . . . . 133

Research Procedures ................... 134

Research Questions .................... 135

Data Comparison Since 1994 . . . . . . . . . . . . . . . . 143

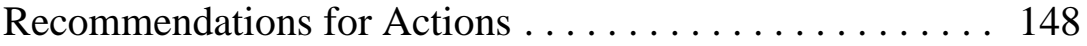

Council Member Training . . . . . . . . . . . . . . . 149

Legislative Review . . . . . . . . . . . . . . . . . 149

State Department Review ... . . . . . . . 150

Research Suggestions . . . . . . . . . . . . . . . . . 150

Researcher's Reflections ................ 152

viii 


\section{TABLE OF CONTENTS}

Page

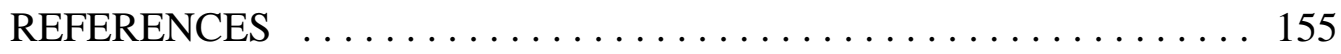

\section{APPENDICES}
A. Survey Instrument $\ldots \ldots \ldots \ldots \ldots \ldots \ldots \ldots \ldots$
B. Responses By School . . . . . . . . . . . . . 176
C. Comparison Tables $\ldots \ldots \ldots \ldots \ldots \ldots \ldots \ldots \ldots$

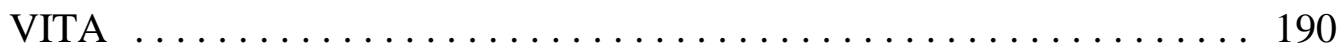




\section{LIST OF TABLES}

TABLE

PAGE

$1 \quad$ Response by Size of School . . . . . . . . . . . . . . . 43

$2 \quad$ Response by Role of Respondent . . . . . . . . . . . . . . 43

3 Response by Longevity of Service . . . . . . . . . . . . . . . . . . 44

$4 \quad$ Response by Attendance of Members . . . . . . . . . . . . . . . 45

$5 \quad$ Response by Participation in Training .............. 46

6 Response by Size of School District . . . . . . . . . . . . . 46

$7 \quad$ Total Response Summary to Question \# $1 \ldots \ldots \ldots \ldots$. . . . . 47

$8 \quad$ Chi Square Results for Question \# $1 \ldots \ldots \ldots \ldots \ldots \ldots$

9 Question \# 1 Responses by School Size ... . . . . . . . . . . . 49

10 Question \# 1 Responses by Longevity . . . . . . . . . . . . . . 50

11 Total Sample Responses for Question \# $2 \ldots \ldots \ldots \ldots \ldots \ldots$

12 Chi Square Results for Question \# $2 \ldots \ldots \ldots \ldots \ldots \ldots$

13 Question \# 2 Responses by Role of Respondent ............ . 53

14 Total Sample Response Summary for Question \# 3 . . . . . . . . . 54

15 Chi Square Results for Question \# $3 \ldots \ldots \ldots \ldots \ldots$

16 Total Sample Response Summary for Question \# 4 . . . . . . . . 56

17 Chi Square Results for Question \# $4 \ldots \ldots \ldots \ldots$ 


\section{LIST OF TABLES}

TABLE

PAGE

18 Question \# 4 Responses by Longevity . . . . . . . . . . . . . . . . 57

19 Question \# 4 Responses by Training $\ldots \ldots \ldots \ldots \ldots \ldots \ldots$

20 Total Sample Response Summary for Question \# 5 . . . . . . . . . . 59

21 Chi Square Results for Question \# $5 \ldots \ldots$. . . . . . . . . . . 59

22 Question \# 5 Responses by School Size ... . . . . . . . . . . 60

23 Total Sample Response Summary for Question \# 6 . . . . . . . . . 61

24 Chi Square Results for Question \# $6 \ldots \ldots \ldots \ldots \ldots$

25 Question \# 6 Responses by Role of Respondent ..... . . . . . . 63

26 Total Sample Response Summary to Question \# 7 . . . . . . . . . 64

27 Chi Square Results for Question \# $7 \ldots \ldots \ldots \ldots \ldots$

28 Question \# 7 Responses by School Size ... . . . . . . . . 66

29 Question \# 7 Responses by Role of Respondent . . . . . . . . . . . 67

30 Question \# 7 Responses by Longevity . . . . . . . . . . . . 68

31 Question \# 7 Responses by Training . . . . . . . . . . . . . 69

32 Total Sample Response Summary to Question \# 8 . . . . . . . . 70

33 Chi Square Results for Question \# $8 \ldots \ldots \ldots \ldots \ldots$

34 Question \# 8 Responses by Longevity . . . . . . . . . . . . . 71 


\section{LIST OF TABLES}

TABLE

PAGE

35 Question \# 8 Responses by Role of Respondent . . . . . . . . . . . 72

36 Question \# 8 Responses by Training ............... 73

37 Question \# 8 Responses by District Size . . . . . . . . . . . . . . . . 74

38 Total Sample Response Summary for Question \# 9 . . . . . . . . . 75

39 Chi Square Results for Question \# $9 \ldots \ldots \ldots \ldots \ldots$

40 Question \# 9 Responses by Role of Respondent . . . . . . . . . . . . 77

41 Question \# 9 Responses by Longevity . . . . . . . . . . . . 78

42 Question \# 9 Responses by Training . . . . . . . . . . . . . . . . . . 79

43 Total Sample Response Summary for Question \# $10 \ldots \ldots$. . . . . 80

44 Chi Square Results for Question \# $10 \ldots \ldots \ldots$. . . . . . . . 80

45 Question \# 10 Responses by Longevity . . . . . . . . . . . . 81

46 Question \# 10 Responses by Role of Respondent . . . . . . . . . 82

47 Question \# 10 Responses by Training $\ldots \ldots \ldots \ldots \ldots \ldots \ldots$

48 Total Sample Response Summary for Question \# $11 \ldots$. . . . . . . . 84

49 Chi Square Results for Question \# $11 \ldots \ldots \ldots \ldots$. . . . . . . 84

50 Question \# 11 Responses by Longevity . . . . . . . . . . . . 85

51 Question \# 11 Responses by Role of Respondent . . . . . . . . . 86 


\section{LIST OF TABLES}

TABLE

PAGE

52 Total Group Response Summary to Question \# $12 \ldots \ldots$. . . . . . 87

$53 \quad$ Chi Square Results for Question \# $12 \ldots \ldots \ldots \ldots$. . . . . . 87

54 Question \# 12 Responses by Role of Respondent . . . . . . . . . . . . 89

55 Total Group Response Summary for Question \# 13 . . . . . . . . . 91

56 Chi Square Results for Question \# $13 \ldots \ldots \ldots \ldots 2$

57 Total Group Response Summary to Question \# 14 . . . . . . . . . . 94

58 Chi Square Results for Question \# $14 \ldots \ldots \ldots \ldots$

59 Question \# 14 Responses by Role of Respondent . . . . . . . . . . 96

60 Summary of Responses for Question \# $15 \ldots \ldots \ldots$. . . . . . 97

61 Summary of Responses for Question \# $16 \ldots \ldots$. . . . . . . . . . 99

62 Summary of Responses for Question \# $17 \ldots \ldots \ldots \ldots$

63 Total Group Response Summary for Question \# $18 \ldots \ldots$

64 Chi Square Results for Question \# 18 . . . . . . . . . . . . . . . 102

65 Question \# 15 Responses by Training . . . . . . . . . . . . 103

66 Total Group Response Summary for Question \# 19 . . . . . . . . . 104

67 Chi Square Results for Question \# 19 . . . . . . . . . . . . . . . . . 104

68 Total Group Response Summary to Question \# $20 \ldots \ldots$. . . . . . 105 


\section{LIST OF TABLES}

TABLE

PAGE

69 Chi Square Results for Question \# $20 \ldots \ldots$. . . . . . . . . 106

70 Question \# 20 Responses by Longevity . . . . . . . . . . . . . . . 107

71 Question \# 20 Responses by Training . . . . . . . . . . . . . 108

72 Total Group Response Summary for Question \# 21 . . . . . . . . 109

73 Chi Square Results for Question \# $21 \ldots$. . . . . . . . . . . . . 109

74 Question \# 21 Responses by Training . . . . . . . . . . . . . 110

75 Question \# 21 Responses by District Size ............. 111

76 Total Group Response Summary for Question \# 22 . . . . . . . 112

77 Chi Square Results for Question \# $22 \ldots \ldots \ldots$. . . . . . . 112

78 Question \# 22 Responses by Longevity . . . . . . . . . . . . . . 113

79 Question \# 22 Responses by Role of Respondent . . . . . . . . . . 114

80 Question \# 22 Responses by Attendance . . . . . . . . . . . . . 115

81 Question \# 22 Responses by Training . . . . . . . . . . . 116

82 Total Group Response Summary for Question \# 23 . . . . . . . . 117

83 Chi Square Results for Question \# $23 \ldots \ldots \ldots \ldots \ldots$

84 Question \# 23 Responses by Training . . . . . . . . . . . . . . 118

85 Question \# 23 Responses by Role of Respondent . . . . . . . . . . . 119 


\section{LIST OF TABLES}

TABLE

PAGE

86 Total Group Response Summary for Question \# 24 . . . . . . . . 120

87 Chi Square Results for Question \# $24 \ldots \ldots \ldots \ldots$

88 Question \# 24 Responses by Training . . . . . . . . . . . . . . 122

89 Question \# 24 Responses by Role of Respondent . . . . . . . . . . . . 123

90 Total Group Response Summary for Question \# $25 \quad \ldots \ldots \ldots$. . . . 124

$91 \quad$ Chi Square Results for Question \# $25 \ldots \ldots \ldots \ldots$

92 Question \# 25 Responses by School Size . . . . . . . . . . . . 126

93 Question \# 25 Responses by Role of Respondent . . . . . . . . . . 127

94 Question \# 25 Responses by Longevity . . . . . . . . . . . . . . . 128

95 Question \# 25 Responses by District Size . . . . . . . . . . . . . . . 129

96 General Comments to Question \# $26 \ldots \ldots \ldots \ldots \ldots \ldots$ 


\section{CHAPTER I}

\section{Introduction}

Site-based management is not a new method of educational administration. In the pioneer days of one-room schools, site-based management was the norm with the teacher being both the academic leader and the business manager. As the town's population continued to grow, so did the size of the school system until a "central office" was created to assure uniformity and standardization. This top-down decision-making process continued for many decades. The distance between the classroom and those who made the decisions about the classroom continued to widen until questions arose about the quality of decision-making.

By the end of the 1980's, many people began to feel more decision-making control was needed at the local level (Noblix and Dempsey 1996). States such as Colorado, Florida, Kentucky, North Carolina, Maine, Washington, Massachusetts, Arkansas, Delaware, and Texas mandated some form of site-based management in an effort to implement school reform. West Virginia considered site-based management after the teacher's strike of 1990. Information gathered during this time implied a need for more local input in the educational decision-making process. The West Virginia Legislature's version of site-based management for 
school reform consisted of three parts; faculty senates, K-4 curriculum teams, and local school improvement councils (Local School Involvement Act of 1990). Of these three, this study has revisited the perceptions of the local school improvement council members.

The school improvement council in West Virginia consists of the principal, three teachers, two service personnel working at the school, three parents of children attending the school, and two at-large members, one representing business, appointed by the principal. If grades seven and higher are located in the school, one student is also a member. Powers of the council include requesting waivers of rules, policies, and regulations and the ability to apply for school of excellence awards. School improvement council programs are encouraged to promote parental involvement, business employee release time for teacher consultation, business advice, volunteer groups, and use of school facilities after school hours.

State Law of West Virginia (18-5A-1) requires the establishment of improvement councils with regularly scheduled meetings. Specific authority has been given to these councils to pursue and accomplish goals they deemed necessary for school improvement. The intent of the West Virginia Legislature in the formulation of school improvement councils, faculty senates, and K-4 
curriculum teams was to:

facilitate and encourage the involvement of the school community in the operation of the local schools to improve educational quality. The article is intended to establish processes at each school which provide opportunities for involvement of the school community in the operation of the local schools and support local initiatives to improve school performance. It is not the intent of this article to restrict the ability of the county board of education in its efforts to create county-wide school improvements (Local School Improvement Act of 1990).

In 1994, Dr. Martha Dean completed her dissertation concerning local school improvement councils. With the councils being in existence only four years at the time, her recommendations for further research proposed that a replication study be completed with council members of the school year 19981999. Comparison of the results of the two studies could provide additional information for use by decision-makers that might result in local school improvement councils attaining their highest goals.

\section{Purpose of the Study}

The purpose of this study is to compare the current perceptions of school improvement council members in West Virginia concerning their roles, functions, successes, and failures in activities of the school improvement councils to Dr. Dean's work which was completed in 1994. By collecting data from school 
improvement council members, a comparison can be made relative to the statewide implementation of the Local School Improvement Act of 1990. Also, by probing the data in relationship to demographic questions on the survey, additional comparisons can be made relative to the size of the school, the role of the respondent, the size of the district, and other factors which might influence the effective operation of the council. Lastly, a comparison of Dr. Dean's earlier findings and the results of this study shall present evidence of continued growth or stagnation of school improvement councils during the last five years.

\section{Statement of the Problem}

The problem researched in this study is: To what extent has reform legislation instituted from the top down impacted the local decision-making processes, particularly those assigned to the school improvement councils in West Virginia? Subproblems included: (1) To what extent have differences in perception aligned with demographic characteristics of the schools? (2) To what extent has the role of the school improvement council member affected his/her perception? (3) Have there been recognizable differences in the way different schools utilized school improvement councils? (4) To what extent have council

members perceived the results of their activities to be successful? (5) What have 
been the activities undertaken by council members? (6) Have changes in the results occurred since 1994 ?

\section{Justification of the Study}

In 1994, Dr. Martha Dean prepared her dissertation on the effectiveness of school reform instituted from the top down, particularly concerning local school improvement councils. The research recommended the study should be replicated with school improvement council members from the school year 1998-99. The study reflected most school improvement council members lacked training and understanding of their various roles. These council members placed their emphasis on physical improvements of the school and little or no emphasis in activities that initiate change in instruction or other pedagogies. This has been identified as a common activity (Dean 1994). Apparently, this is a nationwide need since the Government Accounting Office has identified $\$ 112$ billion is needed to fix the nation's schools (Baines 1997). Although providing a climate conducive to learning is needed, other activities should be included as goals of the local school improvement council. One only needs to pick up the local paper to realize the days of benign neglect of curriculum and school reform are over (Henderson and Hawthorne 1995). Schools are the public nurseries of our future, 
and their wanton neglect entails a kind of silent social suicide (Barber 1992). The general public rates education as the highest priority, ahead of deficit reduction, protecting Social Security and Medicare, and even crime reduction (Hunt 1997). West Virginia schools must have a comprehensive description of school improvement councils to create effective change agents (Dean 1994).

Many doubtful points remain. Has training increased for council members? Is student achievement improving due to council actions? Are members remaining on the council and are community members showing interested involvement? Are principals still trying to control the school improvement council's actions? What reputation, good or bad, do the school improvement councils enjoy? Clarification of these points can only offer assistance towards improving school improvement councils in West Virginia.

\section{Research Questions}

In this study, Dr. Dean's questions will be re-examined:

1. To what extent have local school improvement councils been involved in the decision-making process at their schools?

2. What activities have school improvement councils undertaken since their creation? Since 1994 ? 
3. Have the members of the school improvement councils perceived their activities as improving their schools?

4. What examples of contributions have members of the school improvement councils listed most frequently as strengths?

5. What weaknesses have members of school improvement councils perceived as keeping them from being effective?

6. Were there be similarities and differences between school improvement councils that can be attributed to school size? district size? role of the respondent? longevity of service to the council? attendance? training?

Results derived from this study shall enhance the current knowledge concerning school improvement councils. The Legislature has been inactive concerning school improvement councils since 1993, and these results shall confirm either no further action is needed or perhaps that the legislation needs some adjustment to allow attainment of higher goals. The data gathered in this study shall either confirm earlier findings or show a growth in effectiveness of school improvement councils. Updated information can be used by groups such as the Department of Education and The Education Alliance to update the training kits they create. This study may aid in securing additional funding to provide inservice training for school improvement council members. If progress is shown in 
the data, it can be used to provide an awareness of school improvement council potential. Information from this study may exhibit the value of school improvement councils and share some of the higher goals attained by successful councils. Since this information is coming from a more mature body, it should provide the most current and factual data, to date, for future decision-making concerning school improvement councils.

\section{Limitations}

1. It was be cost prohibitive to survey school improvement councils in all West Virginia schools. Compensation was attempted by selecting 100 schools at random from all West Virginia Schools.

2. This study was limited to perceptions of school improvement council members. There are others, both inside and outside the school system who may have valuable insights with regard to the effective operation of school improvement councils.

3. Other states have varied legal structures for educational decisionmaking. However, this study was conducted only in West Virginia and should not be assumed to apply to all states. The reader should be careful about drawing conclusions as to the applicability of this study to states other than West Virginia. 
4. Since this research was conducted as part of a cohort doctoral program including West Virginia superintendents, the interaction of said superintendents could affect the responses of some of the respondents to the survey and may, therefore, affect the results of this study.

\section{Definitions}

1. School Improvement Council - that body established in every West Virginia school which consists of the principal, who shall serve as an ex officio member, entitled to vote, three teachers elected by the faculty senate of the school, two service personnel employed at the school, three parents or legal guardians of students enrolled at the school elected by the parent members of the school's parent-teacher organization, two at-large members with one representing business, appointed by the principal, and, if the school houses students in grade seven or higher, the student body president or other student, elected by the student body in those grades (Policies to Promote School Board Effectiveness 1993).

2. Reform legislation - that body of the law pertaining to education that was specifically enacted by the West Virginia Legislature between the years of 1988 and 1994.

3. Local decision-making process - the process of arriving at decisions through 
eliciting input from the various groups represented at the school impacted by the decision.

4. Effective - meeting the needs of the organization and the individuals within the organization (Bernard 1938).

5. Success - implementation of suggestions of the decision-making body.

6. Failure - lack of implementation of suggestions of the decision-making body. 


\section{CHAPTER II}

\section{Literature Review}

The literature review was performed to establish the background for sitebased management in general. Many states are making strides toward more local decision-making schools. Many different examples are given showing a wide variety of definitions for site-based management. Effectiveness studies have been completed in the states containing site-based management for some time and now have enough information for a progress report.

\section{Educational Trends}

It seems educational trends swing to and fro between centralization and decentralization. Rural pioneer schools were purposely structured on a site-based model (Taylor and Levine 1991). Unmarried female teachers in town and male teachers in the rural areas had time before and after class to attend to administrative duties since they either lacked a family or farm chores to infringe on their time. The educational programs were decided by the district without a concern for standardization.

After the industrial revolution, large cities began to emerge in America. More workers meant more children and suddenly one small school could not meet 
the educational demands of the city. Organizational regimentation was introduced into the educational system in an effort to offer similar services between the schools (Alfonso, Firth, and Neville 1975; Owens 1987). With the number of schools and student population growing, a division of labor was established to separate teachers from administrators (Draft 1983). As time progressed, management became viewed as a social process (Follet 1987). During the 1940's, Kimball Wiles (1955) evidences group decision-making when he stated:

We release the potential of group numbers by increasing the degree to which each is responsible for his own self direction. A pupil learns more when he assumes more responsibility for learning. A teacher is more effective when he is responsible for making the final decision on what constitutes an appropriate teaching procedure for his class. An official leader releases the potential of a teacher when he shares his authority to make decisions with the person who is to take the action.(p.151)

After the depression, many people felt dejected. They no longer

completely trusted others to make decisions for them (Alfonso et al. 1975). Since theories shield us from confusion, uncertainty, and anxiety, it is not so surprising several theories became evident supporters of participatory decision-making (Boleman and Deal 1991). Efficiency and expediency embraced the classical theory by proposing increased productivity (Owens 1987). Those who believed it was their duty to participate in decision-making were following the doctrines of the democratic theory (Greenberg 1975). For the worker's well-being, many were 
convinced the humanistic theory supported their right to participatory decisionmaking (Dachler and Wilpert 1978).

Not only did participatory decision-making have several supporting theories, it was also noted that, in educational settings, the decision-making could be internal or external (Conway 1984). Internal decision-making was done by teachers, principals, service personnel, and even students. External participants were parents and business leaders as well as voters. In educational settings, participatory decision-making could be voluntary or mandated. It may also be informal as with casual conversation or formal with interactions at meetings. Participatory decision-making can even be direct as with one on one or indirect with representatives speaking on behalf of others (Dachler and Wilpert 1978). With all the various forms of participatory decision-making possible, it should be noted the solutions to yesterday's problem often create impediments to getting anything done in the future, and may even create possibilities for disaster (Boleman and Deal 1991).

\section{Educational Change}

Change can be imposed or voluntary (Marris 1975). Change will create feelings of uncertainty and ambivalence. A personal feeling of accomplishment 
can be gained if change develops as expected. The loss one feels as a result of good or bad change causes the human being to be naturally resistant to change. When politicians and adults ask if change was as good for others as it was for themselves, they should also ask at some point, "Was it good for the children?" (Wirt and Kirt 1992).

In reasoning why change is so difficult, Alvin Toffler states:

...the disturbing fact is that the vast majority of people, including educated and otherwise sophisticated people, find the idea of change so threatening that they attempt to deny its existence. Even many people who understand intellectually that change is accelerating, have not internalized that knowledge, do not take this critical social fact into account in planning their own personal lives (Toffler 1970).

Literature records many unsuccessful attempts to bring about desired school change (Hall and Hord 1987). From these unsuccessful attempts, four factors have been identified as keys to a successful change implementation process: (1) the nature of the change; (2) the school organization; (3) the teacher as the implementor; and (4) the role of the facilitator of change (Hall and Hord 1987).

When change is mandated, even through idealistic purposes, confusion, anxiety, and frustration may result. This is especially true if the one implementing change lacks the understanding of the need for change (Huberman and Miles 
1984). Goodlad, Klein, and associates (1970) found some of the most highly touted innovations in the 1960 's were only partially implemented in the classroom. Now, more than thirty years later, once again parents are striving to continue those innovations (Schmuck and Runkel 1994).

For change to continue, a plan must be implemented. Bennis, Beene, and Chinn (1969) have provided three general strategies of change: empirical-rational, normative-re-educative, and power coercive. If mankind can be convinced the change is in his/her best interest, empirical-rational strategies are being used. Normative-re-educative strategies rely on the normative structures at the socioculture level. Power coercive strategies involve top down mandated changes from authority figures (Bennis et al. 1969).

Resentment is fostered when change is imposed from the outside. Bennis (1966) preferred planned change with mutual goal setting and equally sharing power. Under the best circumstances, change will be met by some resistance. This resistance should be identified, diagnosed, and confronted. Resistance can be greatly diminished if respected members feel ownership of the change and have embraced the ideas of others on what the basic problem is and how the change will be an asset. It is also shown that successful change occurs more often when 
there is a specific identified need for change. This is very important to those who must implement the change (Huberman and Miles 1984).

One specific need is created from the continuing criticism of American schools today. The shareholders believe real reform will result only when teachers, parents, and other community members are given a true voice in the operation of their schools (Walberg et al. 1989). George Noblix and Van Dempsey (1996) recognized the reform movements in education during the 1990's are now beginning the swing to decentralization or "restructuring" of education to allow education to be more responsive to its stakeholders.

Restructuring is defined as organizational features of schools that depart significantly from the conventual patterns of student experiences, teachers' professional work, school governance and leadership, and schools' connection to the broader community (Newman and Rigdon 1997). Restructuring requires the central office staff to become supporters and enablers of the work going on at the school level (Asayesh 1994). The role of the school principal must assume more accountability (Timperley 1998). The principal must also be viewed as someone who can lead, facilitate discussion, and understand curriculum (Aguilar 1995).

Restructuring also requires teachers to alter their roles. They must become satisfied with their environment and inspired by their responsibility (Mehlinger 
1995). Teachers must be more responsive to students' needs and concerns to lower the dropout rate and teach children at various levels (Bickel and Lange 1995). They must provide peer support for each other to increase professional commitment (Singh and Billingsley 1998). School staffs must be provided time, material resources, central office support and technical assistance, staff development opportunities at the site level, and permission to redesign schools if restructuring is to be successful (Oakes and Lipton 1990).

Humans are resistant to change. It is part of our individual psychic as well as our culture. When change is advocated, it is usually for others (Schein 1985). Participatory decision-making can foster shifts in school culture and lead to improved educational processes (Ames and Ames 1994).

With increasing cultural diversity in America, something must be done to bond school communities (Postman 1995). Since school improvement councils include members from the outside community, new cultural ideas may be introduced into the school. Increased student performance can be obtained by stressing material mastery, teacher harmony, parental volunteers, and more planning time (Zigarelli 1996).

Due to the conservative nature of school systems, the least amount of change is allowed to ease outside pressures (Sarason 1990). This restricts the 
number of options for a school system. Teachers, the implementors of school change, must find the end results of change to be feasible, desirable, and embraced by a trusted leader. By working to change school cultures, the school system will be more adaptable to the never ending pressures for educational change in our pluralistic society as it becomes more complex (Levin 1976).

Since the primary task of managing change is motivational, school reform depends on people. Most people dislike being told what to do and regulatory mandates have found little success with teachers in implementing school change (Evans 1993). For proper motivation, Andy Hargreaves (1995) lists the six principles for school renewal as:

1. Moving missions that are reviewed and renewed over time.

2. Policy Realization established by communities of people.

3. Restructuring through team teaching and shared decision-making.

4. Reculturing through collaboration with the wider community.

5. Organizational Learning adjusted to the school's reality.

6. Positive Politics by using the power with the people, not over them.

Teachers must be geared toward continuous learning to provide the proper atmosphere for change (Fullan 1993). Organizations (and societies) that build in 
continuous learning and continuous teaching in jobs at all levels will dominate the twenty-first century (Drucker 1992).

\section{Legislated Educational Reform}

Although mandates may work well at the start of an initiative, a shift towards collaboration may be needed to sustain the change over the long term (Johnson 1996). Sometimes schools follow an imitative process. A school system may adopt a new structure for the institutional purpose of gaining legitimacy instead of the technical purpose of improving (Ogawa 1992). These school systems continue with "business as usual" under the guise of school reform. Obviously, little is done to improve the school situation.

School reform measures were passed by the California Legislature in 1977. Called the California School Improvement Plan, participatory schools were required to establish a site council. The council's charge was to make decisions on the school's needs and improve its weak points. This was accomplished by creating a written plan and securing grants for funding (Berman and Gjelten 1982).

New York City developed a site-based improvement plan in 1979. The New York City Urban Coalition created the Local School Development Program 
on the assumption that all of the school community, including students, parents, service personnel, teachers, and other administrators should be involved in the decision-making process. The principal retained the final decision-making authority (David and Peterson 1984).

During the 1970's, Florida mandated school advisory councils for public schools. These were created as a public relations move. Although school-based councils were created, they lacked authority to make decisions. Though the Florida plan did not decentralize decision-making, it did increase participation of the staff and community (Gomez 1989).

Chicago is the first true example of the move towards site-based management. Their local councils are comprised of two teachers, six parents, two community members, and the principal. Except for the principal, all members were elected by their peers (Walberg and Niemic 1994). Because the majority of the members are non-educators, school governance has not only been transferred from the central office but to the hands of lay people who are not subordinate to the professionals at the school site (Rebarber 1992). The Chicago reform also gave greater authority to the school council concerning budgetary matters and the hiring of new teachers (Bryk et al. 1994). The Illinois Legislature even eliminated the 15-member Chicago Board of Education and replaced it with a 5-member 
board of trustees and a 5-member senior management team lead by a CEO (Harrington-Lueker 1996).

Kentucky also has school improvement councils. They are comprised of three teachers and two parents, selected by their peers, plus the principal. Their responsibilities include control over curriculum, scheduling, use of school space, instructional issues, discipline, personnel hiring and extra curricular activities (David 1994). It isn't hard to imagine this much responsibility was burdensome to the councils and inhibited their effectiveness.

Over the past few years, states have become the sources of innovation and reform. Unintended negative consequences can be the result when reform is initiated for the wrong reasons. The reform process, as well as the intended outcomes, should be carefully screened for adverse side effects or unrealistic goals that waste precious resources. Remember the question stated earlier by Wirt and Kirt (1992), "Was it good for the kids?"

\section{Site-Based Decision-Making}

School-based management is perhaps the major educational innovation of the nineties (Allington and Cunningham 1996). For school districts, the key decentralization questions are: 1 . Which decisions must be made centrally and 
implemented uniformly in all the schools of a district? 2. Which decisions are more appropriate to make at the school site (Cook 1990)? By regularly meeting with management, improved communications and higher morale and creativity can be enhanced (Peters and Austin 1985). This enhancement can be seen by functioning faculty and staff committees, departmental meetings, and teacher driven staff development plans (Kelly 1986).

Levine (1991) identified school based decision-making as a means of initiating change and improving instruction. This reform movement is used to emphasize the need to decentralize and professionalize teaching (DarlingHammond 1993, Schmuck and Runkel 1994).

School-based decision-making reforms were initiated in a variety of ways (Clune and White 1988). Kentucky and West Virginia were mandated through state law. School districts in Cleveland, Ohio, were mandated by a court order. The majority however, were initiated by people in the community who desired to have input. This allows everyone the opportunity to "buy in."

The top heavy bureaucracy of school administration has received much criticism about the lack of cooperation between administrators and teachers (Carnegie Foundation 1986, Goodlad 1984). This criticism was the catalyst for the present reform movement. The intent of the school-based decision-making 
movement is to change the entire system of district and school structure and replace it with new relationships established between principals, teachers, parents, and students (David, Purkey, and White 1988). Support, though it may range from genuine to superficial, comes from national, state, and local political factions, teacher's unions, school board members, teachers, community leaders, and administrators. Meier (1987) believes this support is a direct response to the flood of media coverage stating our present system isn’t performing very well.

Not all people feel schools are in such poor condition. Gerald Bracey (1995) used data analysis by the Center of Educational Reform, sampling by the National Center for Educational Statistics, data collected by the Longitudinal Study of Youth, and the National Educational Longitudinal Study to indicate American education is heading in the right direction. There are still some large differences in our educational offerings and funding (DeYoung and Lawrence 1995). Some feel a large portion of educational funding has gone into the bureaucracy and not directly into the areas aiding student performance (Richman 1994).

Student performance is affected by a variety of influences, the most powerful being the student's ability (Anderson and Keith 1997). The school's responsibility for student failure may have been greatly exaggerated by the 
restructuring reform movement (Elmore and McLaughlin 1988). Societal factors such as declines of the family and community as well as advancing student poverty reduce student performance outcomes. The biggest problem facing schools most mentioned by teachers is the lack of support from the parents (Langdon 1996). The school system cannot accept the blame for these influences.

School-based decision-making models contain many principles of participatory management. Included are expanded decision-making authority, teacher recognition, expanded school focus, and efforts to improve curriculum and instruction (Conley and Bacharach 1990, Levine 1991, David and Peterson 1984). Effective school-based decision-making allows individuals most affected by the decisions the opportunity to make the decisions (White 1988). The belief is those closer to the problem are better able to solve the problem. This theory ignores the lack of expertise at the local level. Wiesner (1987) believes this reform remains most effective due to the increased feeling of responsibility and ownership at the local level. White (1988) feels successful school reform must remain focused on the special needs of the school, the characteristics and culture of the school population and the community, as well as direct impact of the participants on school reform. Individual schools may serve the same mission, but their traditions and organizational ideologies will invariably differ (Hoy and Miskel 1996). 
In a survey of teachers conducted by the Carnegie Foundation in 1988, the perceptions of teacher involvement in school decision-making was categorized. From more than twenty thousand responses from all fifty states, $79 \%$ of the teachers felt they had significant impact in the selection of instructional materials and $63 \%$ felt they could make curriculum decisions. Only $47 \%$ of the respondents believed they had decision-making power concerning standards for student behavior, $45 \%$ the authority to assign students into special classes, $43 \%$ felt influence in designing in-service training, $34 \%$ had influence on teacher evaluation, and 7\% felt influence in hiring new teachers or administrators. Although the Carnegie report implies teachers are limited as to their scope of decision-making, teachers still have a significant desire to participate in a broad range of decision-making (Alutto and Belaso 1972, Crockenberg and Clark 1979).

\section{School Site Councils}

A council comprised of the principal, local teachers and service personnel, students, and community members are generally involved in site-based decisonmaking. This council is the key element of success for effective participatory management (Marburger 1985). How this council is created varies nationwide. Members may volunteer in some states or be elected in others (Clune and White 
1988). Teachers may be selected by a variety of methods or in some cases the entire faculty may be on the council (David 1989). Most typical school-site councils contain five to twelve members who represent the interests of their peers (Payzant 1989).

School councils are responsible for many activities. They may select staff, set and prioritize school goals, make budget recommendations, and conduct needs assessment programs (White 1989). Many councils are advisory groups who recommend actions to a higher authority such as the superintendent or local school board for official action (Pierce 1980, David 1989). Some districts allow their council members more direct input in formal decision-making in the daily operation of the school (Weischadle 1980, Marburger 1985). This allows teachers and community members the feeling of controlling the destiny of their school system.

Benefits and Limitations of School-Based Decision-Making There are several benefits and limitations to school-based decisionmaking. Brubaker and Cole (1997) report that shared decision-making activity can foster a school administrator preparation system potentially much more powerful than similar efforts at colleges and universities. Additional research 
indicates districts with site-based management exhibit increased teacher satisfaction, professionalism, self-esteem, and efficiency (White 1989). In his research on the influence of teacher involvement in school-based decision-making relating to job satisfaction, Schneider (1984) relates:

Administrators should provide, to the greatest extent possible, opportunities for teachers who are affected by a decision, interested in the decision, and/or knowledgeable about the decision to be involved in making the decision. By doing this, teachers' perceived levels of involvement will increase and higher levels of job satisfaction will result.(p. 31)

Adding to the explanation of the importance of teachers being involved in the decision-making process, Rosenholtz (1987) explains:

Jobs that give people autonomy and discretion require that they exercise judgement and choice; in doing so they become aware of themselves as causal agents in their own performance. Loss of the capacity to control the terms of work or to determine what work is to be done, how the work is to be done, or what its aim is to be widens the gap between the knowledge of one's unique contributions to work and any performance efficiency that can be derived from it.(p. 540)

Improved communication is definitely a result of site-based decision-

making. With the decision-making close at hand, lines of communication are short and less chance of misunderstanding prevails. Teachers have a collective voice concerning problems and solutions for teacher improvement. These channels of communication present all members of the community a voice in making educational decisions (White 1989). 
Individual roles on the site-based councils will change with the increase of decision-making authority (Payzant 1989). Due to lack of training or skills, many members may be unable to deal with the new administrative issues assigned to the school-site council. As responsibilities increase, so increases the need for training to develop necessary skills to execute these roles (Malen, Ogawa, and Kranz 1990). Acceptable participant empowerment would include providing the necessary in-service training and technical assistance to enable members to make informed decisions (Parker 1979).

School-based decision-making has taken many forms across America. Its goal should be to solve the problems unique to one's school. Systems attempting to copy the participatory management program of another district will find that what worked for someone else will not necessarily work for them (Ogawa 1992). However, researchers have found basic common ingredients to effective schoolbased decision-making systems (Conley 1993).

Some research indicates there is no significant change in schools due to site-based management (Maken, Ogawa, and Kranz 1990, Wohlsetter and Odden 1992, Fantini 1980). Principals are generally reluctant to share the power of decision-making and therefore attempt to control the membership of the council and the decisions to be made (Malen, Ogawa, and Kranz 1990). Unless there are 
clear parameters of responsibility to focus on educational issues, the council may be limited in their activities (Elmore 1988).

In a case study conducted by the University of Wisconsin-Madison, there is little evidence to suggest parental involvement in school governance affects student learning (Bowles 1980). In the five schools studied, no relationship was discovered between parental involvement and student achievement. A longitudinal study of 50 schools found no relationship between Parent-Teacher Associations and student achievement (Mortimore et al. 1988). Jane David's (1989) review of research on school-based management efforts found very few examples where school councils dealt with any issues more challenging than discipline policy or school beautification.

Components of Successful School-Based Councils

When teacher influence was limited to committees and team teaching, only limited success was achieved (Conley and Bacarach 1990). Sergiovanni (1990) claims success in site-based management can be achieved if the three E's of value-added leadership are followed. They are:

1. Empowerment - when authority and obligation are shared in a way 
that authorizes and legitimizes action, thus increasing responsibility and accountability.

2. Enablement - when means and opportunity are provided and obstacles are removed, permitting empowered persons to make things happen.

3. Enhancement - the leader's role is transformed from manager of workers to leader of leaders. This increases commitment and extraordinary performance.

Other authors suggest a slower pace of implementation for improved results (Allington and Cunningham 1996). Weischadle (1980) suggests a time line as long as three years may be necessary. Some districts have taken as long as five to ten years (Wissler and Ortiz 1986). It is important for members to know what they can and cannot do to avoid confusion (Malen et al. 1990). It is important for local administrators to understand, under site-based management, their authority derives less from the organizational structure and more from teacher assignment of certain authority to the position. This is important since school administrators have often been largely ignored in developing legislation and regulations governing shared decision-making.

It has been shown that successfully implemented school-based management has come from systems who have solicited input from the parents 
and business communities and have used that information to develop new relationships with stakeholders (Klein, Medrich, and Perez-Ferrerio 1996). Training for the participants is another key ingredient. Only after members have been properly trained, can they be expected to perform (Marburger 1985). Training is a good method of building trust in other member's actions. Without the trust derived from training, the participants will revert to the old methods of the past (Malen et al. 1990).

Several characteristics have been identified of site-based councils. Internal elements include a well thought out committee structure, enabling leadership, a focus on student learning, and a focus on adult learning. External elements identified include long-term commitment, curricular guidance, and access to information (David 1996). Another influence on a successful council includes community involvement. All councils contain some percentage of the community and these people should be success-oriented. Parker (1979) indicated that financial support could be a critical point of success. The people who control the cash flow eventually control the outcomes (David 1989).

It is essential that the council have a set of shared goals to reduce the chance of wasting efforts. A good tool to identify goals for positive change is the needs assessment test (Wiles 1993). These tests aren't judgmental and are open- 
ended and intended for internal consumption. Goal attainment also provides a measure of progress. Continued goal attainment builds commitment and cohesiveness among the participants (Timar and David 1991). Building from this cohesiveness, over a period of time participants increase their feelings of trust and two-way communication (Conley 1993). Open two-way communication prohibits hidden agendas.

The final element needed for a successful site-based council is systematic assessment. This feedback allows council members the opportunity of knowing they have achieved their desired results and attained their objective (Malen et al. 1990). Success tends to build success.

Justification for site-based decision-making can be found in the ten precepts offered for a new constitution for the $21^{\text {st }}$ century of American education. Chester Finn (1991) lists them as:

1. Educational systems should be run for the consumers, not the employees and proprietors.

2. Leaders must strive to organize, manage, and judge the system in relation to the outcomes sought.

3. Educators should concentrate on and gauge our success by cognitive learning.

4. Civilian control must be ensured at all times.

5. Expert professionals should be used to provide the means to our ends. 
6. Schools should implement site-based management and authority.

7. Parents and students should be allowed to choose how we will meet the system's norms.

8. A common core of learning and testing should be created.

9. Delivery systems should be varied to include all children.

10. A steady flow of reliable information about student achievement and important outcomes should be maintained.

Current literature supports both successes and failures depending on the definition used for site-based management. Some states have given councils broad authority, including fiscal responsibility, while other states have made mere token efforts. Where does West Virginia fall along this spectrum?

\section{West Virginia School Reform Legislation}

As a result of a teacher's strike in 1990, the West Virginia Legislature in special session passed Article 5A of Chapter 18 of the West Virginia Code. This chapter created three decision-making bodies to operate at the school level. These bodies were described as K-4 curriculum teams, local school improvement councils, and faculty senates. Section 1 allowed community involvement in the 
school improvement councils by stating:

The intent of this article is to facilitate and encourage the involvement of the school community in the operation of the local schools to improve educational quality. This article is intended to establish a process at each school which provides the opportunities for involvement of the school community in the operation of the local schools and to support local initiatives to improve school performance. It is not the intent of this article to restrict the ability of the county board of education in its efforts to effect county-wide school improvements (Local School Involvement Act of 1990).

Membership and procedures for election of said members were also specified in the law. Original legislation named the principal as the council chair but this was later amended to prohibit the principal from controlling the council's actions (Policies to Promote School Board Effectiveness 1993). Council meetings were required at the end of each grading period with the minutes of the meetings recorded.

School improvement councils were also granted certain powers. They can request waivers of county and state board policies by following established procedures. It is even in their power to request a waiver of state law from the Legislature. At least once per year, the local board of education must meet with these councils to hear their advisory comments (Local School Improvement Act of 1990). 
In 1993, the West Virginia Education Fund provided training for business council members and sent out surveys to determine the activities of school improvement councils since their creation in 1990. These surveys revealed three areas of council activity; school curriculum, physical facilities, and awards programs. Physical facilities seem to be the main focus of most school improvement councils. Perhaps it is because these are solid items that readily show improvement whereas curriculum issues offer less immediate gratification. This is another indication that some method of assessment is needed if student improvement is to become the main goal of the school improvement council.

In 1994, Dr. Martha H. Dean completed her dissertation on school improvement councils. Her study confirmed the fact most school councils work toward physical improvements. She also discovered the lack of membership continuity, little or no member training, duplication of organizations, and general dissatisfaction with the business members as other problems. Perhaps some improvement with business members was attained by the training offered by the West Virginia Education Fund. The results of her study clearly established that school improvement councils in West Virginia, although active and meeting regularly, were generally unsure as to their powers and the direction their actions 
should take within the total educational reform picture in West Virginia (Dean 1994).

West Virginia school improvement council members have recognized their successes and failures during the last eight years. First hand responses present the best form of communication. Dr. Dean understood this asset and sought input from these council members. This researcher agrees that council members are the best source of information; therefore, this study attempts to replicate Dr. Deans study in an effort to discover if school improvement councils in West Virginia have become more effective in implementing school reform. 


\title{
CHAPTER III
}

\section{Methodology}

\author{
Introduction
}

There were 783 schools in West Virginia during the 1998-99 school year. Random selection of schools came from a list of schools ranging from smallest to largest in student population. This list was divided into three sections to provide data on the effect, if any, school size had on the research data. The groups were delineated by calculating the mean size of the school in West Virginia and designating schools with a variance of plus one standard deviation from the mean as large and those with a variance of minus one standard deviation from the mean of school population as small (Dean 1994).

\section{Sampling Procedures}

After the schools were divided into the three size groups, 33 large schools, 33 small schools and 34 medium schools were randomly selected. This produced a stratified random sample. The selected schools were reviewed to ensure that schools in counties with both large and small student populations were both represented. A return representing at least $50 \%$ of the schools in each subgroup 
was considered an adequate size to conduct the study and reach consensus. A total of $71 \%$ of the schools returned surveys.

\section{Distribution of Surveys}

Each school principal was sent 12 copies of the survey instrument and letters of instruction concerning survey distribution. A stamped self-addressed envelope was provided to each respondent allowing surveys to be returned to me with complete privacy. The survey materials were initially distributed to selected county superintendents at the November 20, 1998, WVASA conference in Morgantown. These superintendents distributed the survey packets to the principals of the selected schools in their counties. The principals then distributed the individual surveys to their local school improvement council members. After completing the survey, the respondent returned the survey to the researcher in the self-addressed envelope provided with the survey.

\section{Survey Instrument and Internal Validity}

The survey instrument used in this study was the same one used by Dr. Martha Dean in her earlier study that is being used as a baseline. Every effort was made to insure the only variable for change was the perceptions of the school 
improvement council members. The same internal validity applies to this study as it did in the earlier study.

\section{Data Analysis}

The responses were subjected to a chi square analysis using the following six demographic variables: (1) school size; (2) respondent's role; (3) membership term; (4) attendance; (5) training received; and (6) district size. A value of .05 or less was used as the test for significant deviation when comparing subgroups to the total population. The computerized statistical analysis program "Abstat" by Anderson-Bell Corporation was used to organize the data, initiate cross tabulation, and confirm the results. The information gained from these responses has provided the answers to the questions previously stated in Chapter I. Other descriptive statistics such as frequency, per cent, mean, and median were used during the presentation of data as deemed appropriate. The results represented current data that offered insight concerning the advancement or retention of the effectiveness of local school improvement council activities in West Virginia. 


\title{
CHAPTER IV
}

\section{Survey Results}

\author{
Introduction
}

The data used for this study were collected from a sample of local school improvement council members in West Virginia. Because it would be cost prohibitive to collect data from every school in West Virginia, a stratified random sample of 100 schools was chosen to provide the data used in this study. The surveys were distributed at the November WVASA meeting in Morgantown and through the United States Postal Service. The deadline for returning the surveys was December 20, 1998. Of the surveyed schools, $71 \%$ returned responses, thus providing the researcher with the necessary data to complete the analysis. The ABSTAT software statistical package from Anderson-Bell was used to analyze the data.

\section{Description of Respondents}

School improvement council membership is proscribed by law. There must be eleven members per council with an additional student council member if the school contains grades seven or higher. From this membership, respondents returned 276 surveys representing 71 schools. The mean number of responses was 
3.88 with the per school response ranging from one to ten. Returned surveys per strata sampled were 23 of 33 small schools; 23 of 34 medium schools; and 25 of 33 large schools.

Tabulation of results was based on: (1) size of school; (2) role of respondent; (3) number of years of membership on the LSIC; (4) size of the school district; (5) respondent's attendance at scheduled meetings; and (6) respondent's received any formal training concerning the duties of LSIC members. Each response per question was cross tabulated to see if any of the six categories revealed a significant deviation. Although not used as a factor in the mean and standard deviation calculations, the "don't know" response was tabulated.

The six variables did reflect a difference in response to the twenty two questions asked. Using the chi square statistic, significant deviations in response were influenced four times by school size, thirteen times by role of respondent, ten times by longevity of service, only once by attendance, eleven times by training, and three times by district size. Perhaps because there were 105 teachers and only 7 students, role of respondent should be expected to register the most significant deviations. All tabulations were based on the number of surveys returned and the respondents per school returns is listed in Appendix B. 
Demographic Information Collected

The first variable considered was school size. Respondents were asked to select the size their school within the guidelines of the questionnaire. Those guidelines and the respondent's choices are listed in the following table.

TABLE NUMBER 1

RESPONSE BY SIZE OF SCHOOL

\begin{tabular}{|l|c|}
\hline \multicolumn{1}{|c|}{ SIZE OF SCHOOL } & NUMBER OF RESPONSES \\
\hline SMALL (less than 200 students) & 89 \\
\hline MEDIUM (201-500 students) & 94 \\
\hline LARGE (more than 500 students) & 93 \\
\hline
\end{tabular}

Respondents were also asked to identify their role on the school improvement council. Tabulations per role of respondent are listed in the following table.

TABLE NUMBER 2

RESPONSES BY ROLE OF RESPONDENT

\begin{tabular}{|l|c|}
\hline \multicolumn{1}{|c|}{ ROLE } & NUMBER \\
\hline PRINCIPAL & 44 \\
\hline TEACHER & 105 \\
\hline SERVICE PERSONNEL & 52 \\
\hline
\end{tabular}




\begin{tabular}{|l|c|}
\hline \multicolumn{1}{|c|}{ ROLE } & NUMBER \\
\hline PARENT & 44 \\
\hline AT-LARGE MEMBER & 13 \\
\hline AT-LARGE MEMBER, BUSINESS & 11 \\
\hline STUDENT & 7 \\
\hline OTHER & 0 \\
\hline
\end{tabular}

Longevity of council service was also asked of each respondent. The following table reflects their responses.

TABLE NUMBER 3

RESPONSES BY LONGEVITY OF SERVICE

\begin{tabular}{|c|c|}
\hline NUMBER OF YEARS & RESPONSES \\
\hline DON'T KNOW & 9 \\
\hline 1 & 70 \\
\hline 2 & 68 \\
\hline 3 & 41 \\
\hline 4 & 29 \\
\hline $5+$ & 59 \\
\hline
\end{tabular}

The results reflect one-half of the responses were one and two year members and the other one-half were experienced with three or more years of service. Earlier studies reported $66 \%$ composition of 1-2 year members and $34 \%$ 
with three years or greater experience (Dean 94). It appears members are remaining on the council longer. Perhaps this accounts for longevity being the third most significant variable of the six demographic variables.

Attendance was the fourth variable considered in the survey. The respondent's replies are listed in the following table.

TABLE NUMBER 4

RESPONSES BY ATTENDANCE OF MEMBERS

\begin{tabular}{|l|c|}
\hline \multicolumn{1}{|c|}{ RESPONSES } & NUMBER \\
\hline I attend every meeting & 181 \\
\hline I attend most meetings & 85 \\
\hline I attend a few meetings & 6 \\
\hline I am seldom or never at a meeting & 1 \\
\hline
\end{tabular}

More than $66 \%$ of the members responding indicated they attended every meeting. Earlier studies indicated the same percentages of perfect attendance (Dean 94). It appears council members have a strong desire to attend school improvement council meetings.

The training variable was considered to be an important variable in regards to the questions on the survey. Chi square analysis revealed it to be the second 
most significantly deviating variable. The following table lists the number of respondents who did and did not have training.

\section{TABLE NUMBER 5}

\section{RESPONSES BY PARTICIPATION IN TRAINING}

\begin{tabular}{|l|c|}
\hline \multicolumn{1}{|c|}{ RESPONSES } & NUMBER \\
\hline Yes, I participated in training & 60 \\
\hline No, I did not participate in training & 216 \\
\hline
\end{tabular}

The last variable considered was the size of the school district of the participating school. Many respondents were unsure of their school district size. Where omitted or incorrect data were given, the researcher substituted the correct data as listed with the West Virginia Department of Education. The following table exhibits the corrected responses.

\section{TABLE NUMBER 6}

RESPONSES BY SIZE OF SCHOOL DISTRICT

\begin{tabular}{|l|c|}
\hline \multicolumn{1}{|c|}{ SIZE OF SCHOOL DISTRICT } & NUMBER \\
\hline Small (under 2500) & 87 \\
\hline Medium (between 2501-6000) & 104 \\
\hline Large (over 6000) & 85 \\
\hline
\end{tabular}


The Work of the School Improvement Councils

After the demographic information was obtained, the respondent's perceptions concerning the work of the council was requested. Ten questions were used with a forced Likert scale. Their responses indicated how well the councils utilized their authority. A discussion follows each question concerning any significant deviation between the total population and each demographic subgroup previously listed.

QUESTION \#1: To what extent has the School Improvement Council in your school enacted programs that encourage the involvement of parents?

\section{TABLE NUMBER 7}

TOTAL RESPONSE SUMMARY TO QUESTION NUMBER 1

ENACTED PROGRAMS ENCOURAGING PARENTAL INVOLVEMENT

\begin{tabular}{|c|c|c|c|c|c|c|}
\hline RESPONSE & ALWAYS & REGULARLY & OCCASIONALLY & RARELY & NEVER & $\begin{array}{c}\text { DON'T } \\
\text { KNOW }\end{array}$ \\
\hline $\mathrm{N}$ & 42 & 134 & 64 & 21 & 1 & 11 \\
\hline
\end{tabular}

Mean $=2.406$, S.D. $=1.101$

For computation of mean, standard deviation, and other statistical computations, selected responses were converted into numbers. "Always" converted to one (1), "regularly" converted into two (2), "occasionally" converted into three (3), "rarely" converted into four (4), and "never" converted into five (5). 
The "don't know" response was ignored in all statistical computations in this study.

All demographic subgroups were compared to the total population for each question by the use of the chi square statistic. The results of the responses are recorded in the following table.

TABLE NUMBER 8

CHI SQUARE RESULTS OF QUESTION NUMBER 1

ENACTED PROGRAMS ENCOURAGING PARENTAL INVOLVEMENT

\begin{tabular}{|c|c|c|c|}
\hline CATEGORY & CHI SQ. VALUE & $\begin{array}{c}\text { DEGREES } \\
\text { FREEDOM }\end{array}$ & PROBABILITY \\
\hline School Size & 18.851 & 10 & .042 \\
\hline Role of Resp. & 22.797 & 30 & .824 \\
\hline Longevity & 43.531 & 25 & .012 \\
\hline Attendance & 19.157 & 15 & .207 \\
\hline Training & 9.885 & 5 & .079 \\
\hline District Size & 14.996 & 10 & .132 \\
\hline
\end{tabular}

Two categories, using the chi square statistic, deviated from the total population using the .05 test. These are school size and longevity. Responses and measures of central tendency are reported in the following tables. 


\section{TABLE NUMBER 9}

QUESTION NUMBER 1 RESPONSES BY SCHOOL SIZE

ENACTED PROGRAMS ENCOURAGING PARENTAL INVOLVEMENT

\begin{tabular}{|l|c|c|c|}
\hline \multicolumn{1}{|c|}{ RESPONSE } & SMALL & MEDIUM & LARGE \\
\hline always & 19 & 12 & 11 \\
\hline regularly & 53 & 41 & 40 \\
\hline occasionally & 13 & 24 & 27 \\
\hline rarely & 3 & 10 & 8 \\
\hline never & 0 & 1 & 0 \\
\hline don't know & 1 & 5 & 5 \\
\hline MEAN & 1.864 & 2.398 & 2.372 \\
\hline S.D. & .526 & .817 & .683 \\
\hline
\end{tabular}


TABLE NUMBER 10

QUESTION NUMBER 1 RESPONSES BY LONGEVITY

ENACTED PROGRAMS ENCOURAGING PARENTAL INVOLVEMENT

\begin{tabular}{|l|c|c|c|c|c|}
\hline RESPONSE & 1 YR. & 2YRS. & 3 YRS. & 4 YRS. & 5+ YRS. \\
\hline always & 10 & 10 & 4 & 5 & 12 \\
\hline regularly & 30 & 32 & 20 & 16 & 30 \\
\hline occasionally & 17 & 17 & 11 & 4 & 15 \\
\hline rarely & 1 & 8 & 6 & 4 & 1 \\
\hline never & 1 & 0 & 0 & 0 & 0 \\
\hline don't know & 9 & 0 & 0 & 0 & 1 \\
\hline MEAN & 1.646 & 2.343 & 2.463 & 2.241 & 2.086 \\
\hline S.D. & .834 & .774 & .755 & .832 & .527 \\
\hline
\end{tabular}

QUESTION \# 2: As a result of efforts of the School Improvement Council, how often do businesses in your community provide more time to their employees to meet with teachers? 
TABLE NUMBER 11

TOTAL SAMPLE RESPONSES TO QUESTION NUMBER 2

BUSINESSES PROVIDE TIME FOR EMPLOYEES TO MEET TEACHERS

\begin{tabular}{|c|c|c|c|c|c|c|}
\hline RESPONSE & ALWAYS & REGULARLY & OCCASIONALLY & RARELY & NEVER & $\begin{array}{c}\text { DON'T } \\
\text { KNOW }\end{array}$ \\
\hline $\mathrm{N}$ & 7 & 44 & 86 & 67 & 19 & 50 \\
\hline
\end{tabular}

Mean $=3.722$, S.D. $=1.386$

All subgroups were compared to the total population using the chi square statistic and the results of Question \# 2 are listed in the following table.

TABLE NUMBER 12

CHI SQUARE RESULTS FOR QUESTION NUMBER 2

BUSINESSES PROVIDE TIME FOR EMPLOYEES TO MEET TEACHERS

\begin{tabular}{|l|c|c|c|}
\hline \multicolumn{1}{|c|}{ CATEGORY } & CHI SQ. VALUE & $\begin{array}{c}\text { DEGREES } \\
\text { FREEDOM }\end{array}$ & PROBABILITY \\
\hline School Size & 17.923 & 10 & .056 \\
\hline Role of Resp. & 45.332 & 30 & .036 \\
\hline Longevity & 32.979 & 25 & .132 \\
\hline Attendance & 9.049 & 15 & .875 \\
\hline Training & 8.537 & 5 & .129 \\
\hline District Size & 17.069 & 10 & .073 \\
\hline
\end{tabular}


Using the chi square statistic and the .05 test on the responses for Question \# 2, category role of respondent indicated significant deviation from the total population. Results of this category are shown in the following table. 
TABLE NUMBER 13

QUESTION NUMBER 2 RESPONSES BY ROLE OF RESPONDENT

BUSINESSES PROVIDE TIME FOR EMPLOYEES TO MEET TEACHERS

\begin{tabular}{|l|c|c|c|c|c|c|c|c|}
\hline \multicolumn{1}{|c|}{ RESPONSE } & PRINCIPAL & TEACHER & $\begin{array}{c}\text { SERVICE } \\
\text { PERSONNEL }\end{array}$ & PARENT & $\begin{array}{c}\text { AT- } \\
\text { LARGE } \\
\text { MEMBER }\end{array}$ & $\begin{array}{c}\text { AT-LARGE } \\
\text { MEMBER, } \\
\text { BUSINESS }\end{array}$ & STUDENT & OTHER \\
\hline always & 2 & 3 & 1 & 1 & 0 & 0 & 0 & 0 \\
\hline regularly & 9 & 16 & 10 & 8 & 1 & 0 & 0 & 0 \\
\hline occasionally & 17 & 28 & 15 & 14 & 6 & 5 & 1 & 0 \\
\hline rarely & 9 & 32 & 8 & 9 & 6 & 3 & 0 & 0 \\
\hline never & 2 & 11 & 3 & 3 & 0 & 0 & 0 & 0 \\
\hline don't know & 4 & 14 & 15 & 9 & 0 & 3 & 5 & 0 \\
\hline MEAN & 3.000 & 3.355 & 3.054 & 3.142 & 3.384 & 3.375 & 3.000 & 0 \\
\hline S.D. & .810 & .791 & .665 & .751 & .423 & .188 & 0 & 0 \\
\hline
\end{tabular}


QUESTION \# 3: The School Improvement Council in my school seeks advice from the business community.

TABLE NUMBER 14

TOTAL SAMPLE RESPONSE SUMMARY TO QUESTION NUMBER 3 SIC SEEKS ADVICE FROM BUSINESS COMMUNITY

\begin{tabular}{|c|c|c|c|c|c|c|}
\hline RESPONSE & ALWAYS & REGULARLY & OCCAS. & RARELY & NEVER & D. KNOW \\
\hline $\mathrm{N}$ & 17 & 89 & 117 & 27 & 5 & 18 \\
\hline
\end{tabular}

Mean $=2.882$, S.D. $=1.154$

By applying the chi square statistic, a comparison between all categories and the total population was performed on Question \# 3 with the following results. 
TABLE NUMBER 15

CHI SQUARE RESULTS FOR QUESTION NUMBER 3

SIC SEEKS ADVICE FROM BUSINESS COMMUNITY

\begin{tabular}{|l|c|c|c|}
\hline \multicolumn{1}{|c|}{ CATEGORY } & CHI SQ. VALUE & $\begin{array}{c}\text { DEGREES } \\
\text { FREEDOM }\end{array}$ & PROBABILITY \\
\hline School Size & 9.065 & 10 & .526 \\
\hline Role of Resp. & 27.409 & 30 & .602 \\
\hline Longevity & 25.902 & 25 & .413 \\
\hline Attendance & 15.669 & 15 & .404 \\
\hline Training & 7.128 & 5 & .211 \\
\hline District Size & 16.786 & 10 & .079 \\
\hline
\end{tabular}

The statistics reveal that none of the categories had significant deviation in comparison to the total population.

QUESTION \# 4: The School Improvement Council in my school encourages school volunteer programs. 
TABLE NUMBER 16

TOTAL SAMPLE RESPONSE SUMMARY TO QUESTION NUMBER 4

SCHOOL VOLUNTEER PROGRAMS ENCOURAGED

\begin{tabular}{|c|c|c|c|c|c|c|}
\hline RESPONSE & ALWAYS & REGULARLY & OCCAS. & RARELY & NEVER & D. KNOW \\
\hline $\mathrm{N}$ & 98 & 99 & 48 & 16 & 2 & 10 \\
\hline
\end{tabular}

Mean $=2.102$, S.D. $=1.190$

All category responses were compared to the total population using the chi square statistic. Question \# 4 results are in the following table.

TABLE NUMBER 17

CHI SQUARE RESULTS FOR QUESTION NUMBER 4

SCHOOL VOLUNTEER PROGRAMS ENCOURAGED

\begin{tabular}{|l|c|c|c|}
\hline \multicolumn{1}{|c|}{ CATEGORY } & CHI SQ. VALUE & $\begin{array}{c}\text { DEGREES } \\
\text { FREEDOM }\end{array}$ & PROBABILITY \\
\hline School Size & 16.057 & 10 & .098 \\
\hline Role of Resp. & 24.762 & 30 & .737 \\
\hline Longevity & 43.956 & 25 & .011 \\
\hline Attendance & 14.522 & 15 & .486 \\
\hline Training & 13.397 & 5 & .020 \\
\hline District Size & 15.879 & 10 & .103 \\
\hline
\end{tabular}

The categories of longevity and training exhibited a significant deviation 
when compared to the total population. The results are shown in the following tables.

TABLE NUMBER 18

QUESTION NUMBER 4 RESPONSES BY LONGEVITY

SCHOOL VOLUNTEER PROGRAMS ENCOURAGED

\begin{tabular}{|l|c|c|c|c|c|}
\hline RESPONSE & 1 YR. & 2 YRS. & 3 YRS. & 4 YRS. & 5+ YRS. \\
\hline always & 17 & 24 & 12 & 6 & 2 \\
\hline regularly & 24 & 24 & 17 & 1 & 0 \\
\hline occasionally & 13 & 14 & 11 & 2 & 0 \\
\hline rarely & 13 & 11 & 2 & 3 & 0 \\
\hline never & 28 & 23 & 6 & 2 & 0 \\
\hline don't know & 3 & 3 & 0 & 2 & 0 \\
\hline MEAN & 3.115 & 2.947 & 2.437 & 2.571 & 1.000 \\
\hline S.D. & 2.224 & 2.262 & 1.613 & 2.229 & 0 \\
\hline
\end{tabular}


TABLE NUMBER 19

QUESTION NUMBER 4 RESPONSES BY TRAINING

SCHOOL VOLUNTEER PROGRAMS ENCOURAGED

\begin{tabular}{|l|c|c|}
\hline \multicolumn{1}{|c|}{ RESPONSE } & YES & NO \\
\hline always & 29 & 69 \\
\hline regularly & 13 & 86 \\
\hline occasionally & 15 & 33 \\
\hline rarely & 3 & 13 \\
\hline never & 0 & 2 \\
\hline don't know & 0 & 9 \\
\hline MEAN & 1.866 & 1.980 \\
\hline S.D. & .931 & .815 \\
\hline
\end{tabular}

QUESTION \# 5: My School Improvement Council encourages the community to use school facilities for community activities. 
TABLE NUMBER 20

TOTAL SAMPLE RESPONSE SUMMARY TO QUESTION NUMBER 5 COMMUNITY ENCOURAGED TO USE SCHOOL FACILITIES

\begin{tabular}{|c|c|c|c|c|c|c|}
\hline RESPONSE & ALWAYS & REGULARLY & OCCAS. & RARELY & NEVER & $\begin{array}{c}\text { DON'T } \\
\text { KNOW }\end{array}$ \\
\hline $\mathrm{N}$ & 57 & 104 & 53 & 33 & 9 & 17 \\
\hline
\end{tabular}

Mean $=2.575$, S.D. $=1.362$

All categories were compared to the total population using the chi square statistic for Question \# 5 with the following results.

TABLE NUMBER 21

CHI SQUARE RESULTS FOR QUESTION NUMBER 5

COMMUNITY ENCOURAGED TO USE SCHOOL FACILITIES

\begin{tabular}{|l|c|c|c|}
\hline \multicolumn{1}{|c|}{ CATEGORY } & CHI SQ. VALUE & $\begin{array}{c}\text { DEGREES } \\
\text { FREEDOM }\end{array}$ & PROBABILITY \\
\hline School Size & 21.003 & 10 & .021 \\
\hline Role of Resp. & 43.599 & 30 & .052 \\
\hline Longevity & 35.370 & 25 & .074 \\
\hline Attendance & 17.695 & 15 & .279 \\
\hline Training & 5.444 & 5 & .364 \\
\hline District Size & 10.183 & 10 & .425 \\
\hline
\end{tabular}


The statistics indicate the category school size exhibits significant deviation when compared to the total population. The results of this category are listed in the following table.

TABLE NUMBER 22

QUESTION NUMBER 5 RESPONSES BY SCHOOL SIZE

COMMUNITY ENCOURAGED TO USE SCHOOL FACILITIES

\begin{tabular}{|l|c|c|c|}
\hline \multicolumn{1}{|c|}{ RESPONSE } & SMALL & MEDIUM & LARGE \\
\hline always & 26 & 15 & 16 \\
\hline regularly & 36 & 25 & 43 \\
\hline occasionally & 13 & 27 & 13 \\
\hline rarely & 9 & 14 & 10 \\
\hline never & 2 & 5 & 2 \\
\hline don't know & 3 & 7 & 7 \\
\hline MEAN & 2.127 & 2.639 & 1.761 \\
\hline S.D. & 1.076 & 1.268 & 1.133 \\
\hline
\end{tabular}

QUESTION \# 6: The business members on my school's School Improvement

Council actively contribute suggestions with regard to school improvement. 
TABLE NUMBER 23

TOTAL SAMPLE RESPONSE SUMMARY TO QUESTION NUMBER 6 BUSINESS MEMBERS ACTIVELY CONTRIBUTE SUGGESTIONS

\begin{tabular}{|c|c|c|c|c|c|c|}
\hline RESPONSE & ALWAYS & REGULARLY & OCCAS. & RARELY & NEVER & D. KNOW \\
\hline $\mathrm{N}$ & 42 & 113 & 64 & 35 & 5 & 13 \\
\hline
\end{tabular}

Mean $=2.585$, S.D. $=1.224$

All categories were compared to the total population using the chi square statistic for Question \# 6 with the following results.

TABLE NUMBER 24

CHI SQUARE RESULTS FOR QUESTION NUMBER 6 BUSINESS MEMBERS ACTIVELY CONTRIBUTE SUGGESTIONS

\begin{tabular}{|l|c|c|c|}
\hline \multicolumn{1}{|c|}{ CATEGORY } & CHI SQ. VALUE & $\begin{array}{c}\text { DEGREES } \\
\text { FREEDOM }\end{array}$ & PROBABILITY \\
\hline School Size & 12.696 & 10 & .241 \\
\hline Role of Resp. & 49.887 & 30 & .013 \\
\hline Longevity & 31.047 & 25 & .188 \\
\hline Attendance & 8.168 & 15 & .917 \\
\hline Training & 6.943 & 5 & .225 \\
\hline District Size & 2.938 & 10 & .983 \\
\hline
\end{tabular}


The statistics indicate the category role of respondent exhibits significant deviation when compared to the total population. The results of this category are listed in the following table. 
TABLE NUMBER 25

QUESTION NUMBER 6 RESPONSES BY ROLE OF RESPONDENT

BUSINESS MEMBERS ACTIVELY CONTRIBUTE SUGGESTIONS

\begin{tabular}{|l|c|c|c|c|c|c|c|c|}
\hline \multicolumn{1}{|c|}{ RESPONSE } & PRINCIPAL & TEACHER & $\begin{array}{c}\text { SERVICE } \\
\text { PERSONNEL }\end{array}$ & PARENT & $\begin{array}{c}\text { AT-LARGE } \\
\text { MEMBER }\end{array}$ & $\begin{array}{c}\text { AT-LARGE } \\
\text { MEMBER, } \\
\text { BUSINESS }\end{array}$ & STUDENT & OTHER \\
\hline always & 6 & 14 & 10 & 9 & 0 & 0 & 3 & 0 \\
\hline regularly & 20 & 43 & 25 & 13 & 6 & 5 & 1 & 0 \\
\hline occasionally & 13 & 31 & 7 & 9 & 2 & 2 & 0 & 0 \\
\hline rarely & 3 & 12 & 6 & 9 & 3 & 2 & 0 & 0 \\
\hline never & 0 & 2 & 1 & 2 & 0 & 0 & 0 & 0 \\
\hline don't know & 1 & 1 & 3 & 2 & 2 & 2 & 2 & 0 \\
\hline MEAN & 2.309 & 2.460 & 2.244 & 2.571 & 2.181 & 2.666 & 1.250 & 0.000 \\
\hline S.D. & .642 & .876 & .923 & 1.355 & .955 & .600 & .150 & 0 \\
\hline
\end{tabular}


QUESTION \# 7: My School Improvement Council has requested waivers of State Board of Education Policies.

TABLE NUMBER 26

TOTAL SAMPLE RESPONSE SUMMARY TO QUESTION NUMBER 7 WAIVERS REQUESTED OF STATE BOARD POLICIES

\begin{tabular}{|c|c|c|c|c|c|c|}
\hline RESPONSE & ALWAYS & REGULARLY & OCCAS. & RARELY & NEVER & D. KNOW \\
\hline $\mathrm{N}$ & 7 & 15 & 60 & 28 & 77 & 83 \\
\hline
\end{tabular}

Mean $=4.489$, S.D. $=1.400$

All categories were compared to the total population using the chi square statistic for Question \# 7 with the following results. 
TABLE NUMBER 27

CHI SQUARE RESULTS FOR QUESTION NUMBER 7

WAIVERS REQUESTED FOR STATE BOARD POLICIES

\begin{tabular}{|l|c|c|c|}
\hline \multicolumn{1}{|c|}{ CATEGORY } & CHI SQ. VALUE & $\begin{array}{c}\text { DEGREES } \\
\text { FREEDOM }\end{array}$ & PROBABILITY \\
\hline School Size & 19.175 & 10 & .381 \\
\hline Role of Resp. & 50.067 & 30 & .012 \\
\hline Longevity & 61.030 & 25 & .000 \\
\hline Attendance & 11.942 & 15 & .683 \\
\hline Training & 28.446 & 5 & .000 \\
\hline District Size & 17.394 & 10 & .066 \\
\hline
\end{tabular}

The statistics indicate the categories school size, role of respondent, longevity, and training all had significant deviations when compared to the total population. The results from these categories are listed in the following tables. 
TABLE NUMBER 28

QUESTION NUMBER 7 RESPONSES BY SCHOOL SIZE

WAIVERS REQUESTED OF STATE BOARD POLICIES

\begin{tabular}{|l|c|c|c|}
\hline \multicolumn{1}{|c|}{ RESPONSE } & SMALL & MEDIUM & LARGE \\
\hline always & 4 & 2 & 1 \\
\hline regularly & 7 & 2 & 6 \\
\hline occasionally & 27 & 16 & 17 \\
\hline rarely & 6 & 13 & 9 \\
\hline never & 26 & 28 & 23 \\
\hline don't know & 16 & 32 & 35 \\
\hline MEAN & 3.185 & 4.032 & 3.389 \\
\hline S.D. & 1.406 & .760 & .795 \\
\hline
\end{tabular}


TABLE NUMBER 29

QUESTION NUMBER 7 RESPONSES BY ROLE OF RESPONDENT

WAIVERS REQUESTED OF STATE BOARD POLICIES

\begin{tabular}{|l|c|c|c|c|c|c|c|c|}
\hline RESPONSES & PRINCIPAL & TEACHER & $\begin{array}{c}\text { SERVICE } \\
\text { PERSONNEL }\end{array}$ & PARENT & $\begin{array}{c}\text { AT-LARGE } \\
\text { MEMBER }\end{array}$ & $\begin{array}{c}\text { AT-LARGE } \\
\text { MEMBER, } \\
\text { BUSINESS }\end{array}$ & STUDENT & OTHER \\
\hline always & 1 & 3 & 1 & 1 & 0 & 1 & 0 & 0 \\
\hline regularly & 0 & 9 & 3 & 2 & 0 & 1 & 0 & 0 \\
\hline occasionally & 16 & 19 & 10 & 9 & 2 & 4 & 0 & 0 \\
\hline rarely & 7 & 9 & 8 & 3 & 1 & 0 & 0 & 0 \\
\hline never & 17 & 33 & 7 & 15 & 3 & 1 & 1 & 0 \\
\hline don't know & 2 & 29 & 22 & 14 & 7 & 4 & 5 & 0 \\
\hline MEAN & 3.951 & 3.821 & 3.586 & 3.966 & 4.166 & 2.857 & 5.000 & 0 \\
\hline S.D. & .998 & 1.116 & .661 & .953 & 1.903 & .886 & 0 & 0 \\
\hline
\end{tabular}


TABLE NUMBER 30

QUESTION NUMBER 7 RESPONSES BY LONGEVITY

WAIVERS REQUESTED OF STATE BOARD POLICIES

\begin{tabular}{|l|c|c|c|c|c|}
\hline RESPONSE & 1 YR. & 2 YRS. & 3 YRS. & 4 YRS. & 5+ YRS. \\
\hline always & 1 & 1 & 1 & 0 & 4 \\
\hline regularly & 3 & 5 & 2 & 4 & 0 \\
\hline occasionally & 10 & 10 & 10 & 7 & 23 \\
\hline rarely & 5 & 10 & 2 & 3 & 6 \\
\hline never & 12 & 16 & 16 & 12 & 18 \\
\hline don't know & 36 & 24 & 10 & 3 & 7 \\
\hline MEAN & 3.774 & 3.833 & 3.967 & 3.884 & 3.666 \\
\hline S.D. & .628 & .828 & 1.074 & 1.733 & 1.251 \\
\hline
\end{tabular}


TABLE NUMBER 31

QUESTION NUMBER 7 RESPONSES BY TRAINING

WAIVERS REQUESTED OF STATE BOARD POLICIES

\begin{tabular}{|l|c|c|}
\hline \multicolumn{1}{|c|}{ RESPONSE } & YES & NO \\
\hline always & 5 & 2 \\
\hline regularly & 2 & 13 \\
\hline occasionally & 20 & 40 \\
\hline rarely & 10 & 18 \\
\hline never & 17 & 59 \\
\hline don't know & 6 & 77 \\
\hline MEAN & 3.592 & 3.901 \\
\hline S.D. & 1.374 & .806 \\
\hline
\end{tabular}

QUESTION \# 8: My School Improvement Council has obtained waivers of State Board Policies. 
TABLE NUMBER 32

TOTAL SAMPLE RESPONSE SUMMARY TO QUESTION NUMBER 8 OBTAINED WAIVERS OF STATE BOARD POLICIES

\begin{tabular}{|c|c|c|c|c|c|c|}
\hline $\begin{array}{c}\text { RESPONS } \\
\mathrm{E}\end{array}$ & ALWAYS & $\begin{array}{c}\text { REGULARL } \\
\mathrm{Y}\end{array}$ & OCCAS. & $\begin{array}{c}\text { RAREL } \\
\mathrm{Y}\end{array}$ & NEVER & $\begin{array}{c}\text { DON'T } \\
\text { KNOW }\end{array}$ \\
\hline $\mathrm{N}$ & 8 & 16 & 47 & 24 & 78 & 96 \\
\hline
\end{tabular}

Mean $=4.621$, S.D. $=1.421$

All categories were compared to the total population using the chi square statistic for Question \# 8 with the following results.

TABLE NUMBER 33

CHI SQUARE RESULTS FOR QUESTION NUMBER 8

OBTAINED WAIVERS OF STATE BOARD POLICIES

\begin{tabular}{|l|c|c|c|}
\hline \multicolumn{1}{|c|}{ CATEGORY } & CHI SQ. VALUE & $\begin{array}{c}\text { DEGREES } \\
\text { FREEDOM }\end{array}$ & PROBABILITY \\
\hline School Size & 18.298 & 10 & .051 \\
\hline Role of Resp. & 61.928 & 30 & .001 \\
\hline Longevity & 56.837 & 25 & .001 \\
\hline Attendance & 11.215 & 15 & .737 \\
\hline Training & 30.649 & 5 & .000 \\
\hline District Size & 24.218 & 10 & .007 \\
\hline
\end{tabular}


The statistics indicate the categories role of respondent, longevity, training, and district size all exhibited significant deviation when compared to the total population. The results from these categories are listed in the following tables.

TABLE NUMBER 34

QUESTION NUMBER 8 RESPONSES BY LONGEVITY OBTAINED WAIVERS OF STATE BOARD POLICIES

\begin{tabular}{|l|c|c|c|c|c|}
\hline \multicolumn{1}{|c|}{ RESPONSE } & 1 YRS. & 2 YRS. & 3 YRS. & 4 YRS. & 5+ YRS. \\
\hline always & 1 & 1 & 1 & 1 & 0 \\
\hline regularly & 5 & 3 & 3 & 3 & 1 \\
\hline occasionally & 8 & 9 & 7 & 3 & 0 \\
\hline rarely & 4 & 7 & 3 & 4 & 2 \\
\hline never & 10 & 16 & 15 & 12 & 3 \\
\hline don't know & 39 & 29 & 12 & 6 & 3 \\
\hline MEAN & 3.607 & 3.944 & 3.965 & 3.826 & 4.166 \\
\hline S.D. & .647 & .717 & 1.074 & 1.311 & 1.389 \\
\hline
\end{tabular}


TABLE NUMBER 35

QUESTION NUMBER 8 RESPONSES BY ROLE OF RESPONDENT

OBTAINED WAIVERS OF STATE BOARD POLICIES

\begin{tabular}{|l|c|c|c|c|c|c|c|c|}
\hline \multicolumn{1}{|c|}{ RESPONSE } & PRINCIPAL & TEACHER & $\begin{array}{c}\text { SERVICE } \\
\text { PERSONNEL }\end{array}$ & PARENT & $\begin{array}{c}\text { AT-LARGE } \\
\text { MEMBER }\end{array}$ & $\begin{array}{c}\text { AT-LARGE } \\
\text { MEMBER, } \\
\text { BUSINESS }\end{array}$ & STUDENT & OTHER \\
\hline always & 2 & 3 & 1 & 1 & 0 & 1 & 0 & 0 \\
\hline regularly & 1 & 10 & 4 & 1 & 0 & 0 & 0 & 0 \\
\hline occasionally & 11 & 16 & 8 & 5 & 3 & 4 & 0 & 0 \\
\hline rarely & 9 & 5 & 8 & 1 & 1 & 0 & 0 & 0 \\
\hline never & 18 & 33 & 6 & 17 & 2 & 1 & 1 & 0 \\
\hline don't know & 2 & 35 & 23 & 19 & 7 & 5 & 5 & 0 \\
\hline MEAN & 3.975 & 3.820 & 3.518 & 4.280 & 3.833 & 3.000 & 5.000 & 0.000 \\
\hline S.D. & 1.214 & 1.127 & .668 & .768 & .403 & .800 & 0 & 0 \\
\hline
\end{tabular}


TABLE NUMBER 36

QUESTION NUMBER 8 RESPONSES BY TRAINING

OBTAINED WAIVERS OF STATE BOARD POLICIES

\begin{tabular}{|l|c|c|}
\hline \multicolumn{1}{|c|}{ RESPONSE } & YES & NO \\
\hline always & 6 & 13 \\
\hline regularly & 3 & 31 \\
\hline occasionally & 16 & 17 \\
\hline rarely & 7 & 58 \\
\hline never & 19 & 89 \\
\hline don't know & 7 & 3.942 \\
\hline MEAN & 3.588 & .760 \\
\hline S.D. & 1.620 & 2 \\
\hline
\end{tabular}


TABLE NUMBER 37

QUESTION NUMBER 8 RESPONSES BY DISTRICT SIZE

OBTAINED WAIVERS OF STATE BOARD POLICIES

\begin{tabular}{|l|c|c|c|}
\hline \multicolumn{1}{|c|}{ RESPONSE } & SMALL & MEDIUM & LARGE \\
\hline always & 1 & 5 & 2 \\
\hline regularly & 5 & 4 & 7 \\
\hline occasionally & 24 & 9 & 14 \\
\hline rarely & 7 & 12 & 5 \\
\hline never & 15 & 31 & 31 \\
\hline don't know & 35 & 39 & 22 \\
\hline MEAN & 3.576 & 3.983 & 3.949 \\
\hline S.D. & .682 & 1.020 & 1.136 \\
\hline
\end{tabular}

QUESTION \# 9: My School Improvement Council has requested waivers of Local Board Policies. 
TABLE NUMBER 38

TOTAL RESPONSE SUMMARY TO QUESTION NUMBER 9

WAIVERS REQUESTED OF LOCAL BOARD POLICIES

\begin{tabular}{|c|c|c|c|c|c|c|}
\hline RESPONSE & ALWAYS & REGULARLY & OCCAS & RARELY & NEVER & $\begin{array}{c}\text { DON'T } \\
\text { KNOW }\end{array}$ \\
\hline $\mathrm{N}$ & 5 & 18 & 51 & 38 & 72 & 87 \\
\hline
\end{tabular}

Mean $=4.531$, S.D. $=1.376$

All categories were compared to the total population using the chi square statistic and the .05 test for Question \# 9 with the following results.

TABLE NUMBER 39

CHI SQUARE RESULTS FOR QUESTION NUMBER 9

WAIVERS REQUESTED OF LOCAL BOARD POLICIES

\begin{tabular}{|l|c|c|c|}
\hline \multicolumn{1}{|c|}{ CATEGORY } & CHI SQ. VALUE & $\begin{array}{c}\text { DEGREES } \\
\text { FREEDOM }\end{array}$ & PROBABILITY \\
\hline School Size & 14.076 & 10 & .170 \\
\hline Role of Resp. & 52.423 & 30 & .007 \\
\hline Longevity & 60.752 & 25 & .000 \\
\hline Attendance & 23.263 & 15 & .079 \\
\hline Training & 18.203 & 5 & .003 \\
\hline District Size & 12.158 & 10 & .275 \\
\hline
\end{tabular}


The statistics indicate the categories role of respondent, longevity, and training show significant deviation when compared to the total population using the .05 test. The results of these categories are listed in the following tables. 
TABLE NUMBER 40

QUESTION NUMBER 9 RESPONSES BY ROLE OF RESPONDENT

WAIVERS REQUESTED OF LOCAL BOARD POLICIES

\begin{tabular}{|l|c|c|c|c|c|c|c|c|}
\hline \multicolumn{1}{|c|}{ RESPONSE } & PRINCIPAL & TEACHER & $\begin{array}{c}\text { SERVICE } \\
\text { PERSONNEL }\end{array}$ & PARENT & $\begin{array}{c}\text { AT-LARGE } \\
\text { MEMBER }\end{array}$ & $\begin{array}{c}\text { AT-LARGE } \\
\text { MEMBER, } \\
\text { BUSINESS }\end{array}$ & STUDENT & OTHER \\
\hline always & 0 & 1 & 1 & 2 & 0 & 1 & 0 & 0 \\
\hline regularly & 2 & 9 & 4 & 1 & 1 & 1 & 0 & 0 \\
\hline occasionally & 8 & 23 & 9 & 7 & 2 & 2 & 0 & 0 \\
\hline rarely & 12 & 15 & 6 & 3 & 2 & 0 & 0 & 0 \\
\hline never & 17 & 28 & 7 & 15 & 4 & 1 & 0 & 0 \\
\hline don't know & 4 & 28 & 23 & 16 & 4 & 6 & 6 & 0 \\
\hline MEAN & 4.128 & 3.789 & 3.518 & 4.000 & 4.000 & 2.800 & 0 & 0 \\
\hline S.D. & .770 & .899 & .709 & 1.023 & .833 & .880 & 0 & 0 \\
\hline
\end{tabular}


TABLE NUMBER 41

QUESTION NUMBER 9 RESPONSES BY LONGEVITY

WAIVERS REQUESTED OF LOCAL BOARD POLICIES

\begin{tabular}{|l|c|c|c|c|c|}
\hline RESPONSE & 1 YR. & 2 YRS. & 3 YRS. & 4 YRS. & 5+ YRS. \\
\hline always & 1 & 1 & 1 & 1 & 1 \\
\hline regularly & 4 & 2 & 2 & 3 & 7 \\
\hline occasionally & 10 & 10 & 9 & 4 & 16 \\
\hline rarely & 2 & 11 & 10 & 3 & 8 \\
\hline never & 12 & 15 & 12 & 11 & 20 \\
\hline don't know & 39 & 28 & 7 & 6 & 6 \\
\hline MEAN & 3.689 & 3.948 & 3.882 & 3.909 & 3.750 \\
\hline S.D. & .660 & .635 & .938 & 1.327 & 1.224 \\
\hline
\end{tabular}


TABLE NUMBER 42

QUESTION NUMBER 9 RESPONSES BY TRAINING

WAIVERS REQUESTED OF LOCAL BOARD POLICIES

\begin{tabular}{|l|c|c|}
\hline \multicolumn{1}{|c|}{ RESPONSE } & YES & NO \\
\hline always & 2 & 3 \\
\hline regularly & 2 & 16 \\
\hline occasionally & 12 & 39 \\
\hline rarely & 13 & 25 \\
\hline never & 23 & 48 \\
\hline don't know & 8 & 79 \\
\hline MEAN & 4.019 & 3.755 \\
\hline S.D. & 1.034 & .814 \\
\hline
\end{tabular}

QUESTION \# 10: My School Improvement Council has obtained waivers of Local Board Policies. 
TABLE NUMBER 43

TOTAL SAMPLE RESPONSE SUMMARY TO QUESTION NUMBER 10

OBTAINED WAIVERS OF LOCAL BOARD POLICIES

\begin{tabular}{|c|c|c|c|c|c|c|}
\hline RESPONSE & ALWAYS & REGULARLY & OCCAS. & RARELY & NEVER & $\begin{array}{c}\text { DON'T } \\
\text { KNOW }\end{array}$ \\
\hline $\mathrm{N}$ & 5 & 19 & 45 & 28 & 77 & 96 \\
\hline
\end{tabular}

Mean $=4.633$, S.D. $=1.389$

All categories were compared to the total population using the chi square statistic for Question \# 10 with the following results.

TABLE NUMBER 44

CHI SQUARE RESULTS FOR QUESTION NUMBER 10 OBTAINED WAIVERS OF LOCAL BOARD POLICIES

\begin{tabular}{|l|c|c|c|}
\hline CATEGORIES & CHI SQ. VALUE & $\begin{array}{c}\text { DEGREES } \\
\text { FREEDOM }\end{array}$ & PROBABILITY \\
\hline School Size & 12.793 & 10 & .236 \\
\hline Role of Resp. & 50.723 & 30 & .011 \\
\hline Longevity & 62.207 & 25 & .000 \\
\hline Attendance & 19.066 & 15 & .211 \\
\hline Training & 18.866 & 5 & .002 \\
\hline District Size & 15.329 & 10 & .121 \\
\hline
\end{tabular}


The statistical results indicate the categories role of respondent, longevity, and training show significant deviation when compared to the total population using the .05 test. The results from these categories are listed in the following tables.

TABLE NUMBER 45

QUESTION NUMBER 10 RESPONSES BY LONGEVITY OBTAINED WAIVERS OF LOCAL BOARD POLICIES

\begin{tabular}{|l|c|c|c|c|c|}
\hline RESPONSE & 1 YR. & 2 YRS. & 3 YRS. & 4 YRS. & 5+ YRS. \\
\hline always & 1 & 1 & 1 & 0 & 1 \\
\hline regularly & 4 & 2 & 2 & 3 & 8 \\
\hline occasionally & 10 & 8 & 10 & 2 & 14 \\
\hline rarely & 2 & 9 & 5 & 2 & 7 \\
\hline never & 11 & 15 & 14 & 13 & 22 \\
\hline don't know & 40 & 30 & 9 & 9 & 6 \\
\hline MEAN & 3.642 & 4.057 & 3.906 & 4.250 & 3.788 \\
\hline S.D. & .633 & .627 & 1.018 & .920 & 1.210 \\
\hline
\end{tabular}


TABLE NUMBER 46

\section{QUESTION NUMBER 10 RESPONSES BY ROLE OF RESPONDENT}

OBTAINED WAIVERS OF LOCAL BOARD POLICIES

\begin{tabular}{|l|c|c|c|c|c|c|c|c|}
\hline RESPONSE & PRINCIPAL & TEACHER & $\begin{array}{c}\text { SERVICE } \\
\text { PERSONNEL }\end{array}$ & PARENT & $\begin{array}{c}\text { AT-LARGE } \\
\text { MEMBER }\end{array}$ & $\begin{array}{c}\text { AT-LARGE } \\
\text { MEMBER, } \\
\text { BUSINESS }\end{array}$ & STUDENT & OTHER \\
\hline always & 1 & 1 & 1 & 1 & 0 & 1 & 0 & 0 \\
\hline regularly & 2 & 10 & 4 & 1 & 1 & 1 & 0 & 0 \\
\hline occasionally & 8 & 20 & 9 & 4 & 2 & 2 & 0 & 0 \\
\hline rarely & 9 & 9 & 6 & 2 & 2 & 0 & 0 & 0 \\
\hline never & 19 & 30 & 7 & 17 & 3 & 1 & 0 & 0 \\
\hline don't know & 4 & 33 & 24 & 18 & 5 & 6 & 6 & 0 \\
\hline MEAN & 4.102 & 3.814 & 3.518 & 4.320 & 3.875 & 2.800 & 0.000 & 0.000 \\
\hline S.D. & 1.038 & .945 & .695 & .749 & .740 & .880 & 0 & 0 \\
\hline
\end{tabular}


TABLE NUMBER 47

QUESTION NUMBER 10 RESPONSES BY TRAINING

OBTAINED WAIVERS OF LOCAL BOARD POLICIES

\begin{tabular}{|l|c|c|}
\hline \multicolumn{1}{|c|}{ RESPONSE } & YES & NO \\
\hline always & 2 & 3 \\
\hline regularly & 2 & 17 \\
\hline occasionally & 12 & 33 \\
\hline rarely & 9 & 19 \\
\hline never & 25 & 51 \\
\hline don't know & 9 & 87 \\
\hline MEAN & 4.060 & 3.796 \\
\hline S.D. & 1.083 & .832 \\
\hline
\end{tabular}

QUESTION \# 11: The School Improvement Council at my school has developed a mentorship program. For purposes of statistical analysis, "yes" is numbered one (1) and "no" is numbered two (2). As usual, the choice "don't know" was not considered in the computations. The same procedure was followed for Question \# 12. 
TABLE NUMBER 48

SAMPLE RESPONSE SUMMARY TO QUESTION NUMBER 11

MENTORSHIP PROGRAMS DEVELOPED

\begin{tabular}{|c|c|c|}
\hline RESPONSE & YES & NO \\
\hline $\mathrm{N}$ & 60 & 187 \\
\hline
\end{tabular}

Mean $=1.753$, S.D. $=0.441$

All categories were compared to the total population using the chi square statistic for Question \# 11 with the following results.

TABLE NUMBER 49

CHI SQUARE RESULTS FOR QUESTION NUMBER 11

MENTORSHIP PROGRAMS DEVELOPED

\begin{tabular}{|l|c|c|c|}
\hline \multicolumn{1}{|c|}{ RESPONSE } & CHI SQ. VALUE & $\begin{array}{c}\text { DEGREES } \\
\text { FREEDOM }\end{array}$ & PROBABILITY \\
\hline School Size & 2.024 & 2 & .364 \\
\hline Role of Resp. & 2.955 & 7 & .000 \\
\hline Longevity & 11.283 & 5 & .046 \\
\hline Attendance & 2.763 & 6 & .430 \\
\hline Training & 1.284 & 1 & .257 \\
\hline District Size & 2.164 & 2 & .339 \\
\hline
\end{tabular}

The statistics indicate the categories role of respondent and longevity had significant deviation when compared to the total population using the .05 test. 
The results of these categories are listed in the following tables.

TABLE NUMBER 50

QUESTION NUMBER 11 RESPONSES BY LONGEVITY

MENTORSHIP PROGRAMS DEVELOPED

\begin{tabular}{|l|c|c|c|c|c|}
\hline RESPONSE & 1 YR. & 2 YRS. & 3 YRS. & 4 YRS. & 5+ YRS. \\
\hline Yes & 1 & 21 & 6 & 4 & 12 \\
\hline No & 2 & 44 & 29 & 20 & 45 \\
\hline Don't Know & 0 & 0 & 1 & 0 & 0 \\
\hline MEAN & 1.666 & 1.676 & 1.828 & 1.833 & 1.789 \\
\hline S.D. & .334 & .222 & .142 & .145 & .169 \\
\hline
\end{tabular}


TABLE NUMBER 51

QUESTION NUMBER 11 RESPONSES BY ROLE OF RESPONDENT

MENTORSHIP PROGRAMS DEVELOPED

\begin{tabular}{|l|c|c|c|c|c|c|c|c|}
\hline RESPONSE & PRINCIPAL & TEACHER & $\begin{array}{c}\text { SERVICE } \\
\text { PERSONNEL }\end{array}$ & PARENT & $\begin{array}{c}\text { AT-LARGE } \\
\text { MEMBER }\end{array}$ & $\begin{array}{c}\text { AT-LARGE } \\
\text { MEMBER, } \\
\text { BUSINESS }\end{array}$ & STUDENT & OTHER \\
\hline Yes & 8 & 21 & 14 & 9 & 4 & 2 & 2 & 0 \\
\hline No & 36 & 76 & 27 & 34 & 7 & 5 & 2 & 0 \\
\hline Don't Know & 0 & 0 & 0 & 0 & 1 & 0 & 0 & 0 \\
\hline MEAN & 1.818 & 1.783 & 1.658 & 1.790 & 1.636 & 1.714 & 1.500 & 0.000 \\
\hline S.D. & .152 & .171 & .230 & .169 & .231 & .238 & .333 & 0 \\
\hline
\end{tabular}


QUESTION \# 12: The School Improvement Council at my school has applied for a "School of Excellence" award.

TABLE NUMBER 52

TOTAL SAMPLE RESPONSE TO QUESTION NUMBER 12

APPLIED FOR “SCHOOL OF EXCELLENCE” AWARD

\begin{tabular}{|c|c|c|}
\hline RESPONSE & YES & NO \\
\hline $\mathrm{N}$ & 87 & 159 \\
\hline
\end{tabular}

Mean $=1.646$, S.D. $=0.479$

All categories were compared to the total population using the chi square statistic and the .05 test for Question \# 12 with the following results.

TABLE NUMBER 53

CHI SQUARE RESULTS FOR QUESTION NUMBER 12

APPLIED FOR “SCHOOL OF EXCELLENCE” AWARD

\begin{tabular}{|l|c|c|c|}
\hline \multicolumn{1}{|c|}{ CATEGORY } & CHI SQ. VALUE & $\begin{array}{c}\text { DEGREES } \\
\text { FREEDOM }\end{array}$ & PROBABILITY \\
\hline School Size & 2.586 & 2 & .275 \\
\hline Role of Resp. & 13.382 & 6 & .037 \\
\hline Longevity & 3.665 & 5 & .599 \\
\hline Attendance & 6.294 & 3 & .098 \\
\hline Training & 0.015 & 1 & .902 \\
\hline District Size & 1.826 & 2 & .401 \\
\hline
\end{tabular}


The statistics, using the .05 test, indicate the category role of respondent as exhibiting significant deviation when compared to the total population. The results of this category are listed in the following table. 
TABLE NUMBER 54

QUESTION NUMBER 12 RESULTS BY ROLE OF RESPONDENT

APPLIED FOR “SCHOOL OF EXCELLENCE” AWARD

\begin{tabular}{|l|c|c|c|c|c|c|c|c|}
\hline RESPONSE & PRINCIPAL & TEACHER & $\begin{array}{c}\text { SERVICE } \\
\text { PERSONNEL }\end{array}$ & PARENT & $\begin{array}{c}\text { AT-LARGE } \\
\text { MEMBER }\end{array}$ & $\begin{array}{c}\text { AT-LARGE } \\
\text { MEMBER, } \\
\text { BUSINESS }\end{array}$ & STUDENT & OTHER \\
\hline Yes & 12 & 27 & 21 & 16 & 4 & 6 & 1 & 0 \\
\hline No & 32 & 74 & 21 & 22 & 6 & 3 & 1 & 0 \\
\hline Don't Know & 0 & 0 & 0 & 0 & 0 & 0 & 0 & 0 \\
\hline MEAN & 1.727 & 1.732 & 1.500 & 1.578 & 1.600 & 1.333 & 1.500 & 0 \\
\hline S.D. & .203 & .198 & .256 & .250 & .267 & .250 & .500 & 0 \\
\hline
\end{tabular}


QUESTION \# 13: On our School Improvement Council, the leadership role is usually assumed by: (select only one). The procedure of calculation for this question and also Question \# 14 is the same. The seven roles were numbered similarly to the demographic question number \# 3 for statistical purposes.

Principal was assigned the number 1, teacher was assigned 2, service personnel was assigned 3, parent was assigned 4, at-large and at-large business were combined and assigned 5, student was assigned 6, no one was assigned 7, and other was assigned 8 . The total group responses are summarized in the following table. 
TABLE NUMBER 55

TOTAL GROUP RESPONSE SUMMARY TO QUESTION NUMBER 13

ASSUMPTION OF LEADERSHIP ROLE

\begin{tabular}{|c|c|c|c|c|c|c|c|c|}
\hline RESPONSE & PRINCIPAL & TEACHER & $\begin{array}{c}\text { SERVICE } \\
\text { PERSONNEL }\end{array}$ & PARENT & $\begin{array}{c}\text { AT-LARGE } \\
\text { MEMBER }\end{array}$ & STUDENT & $\begin{array}{c}\text { NO } \\
\text { ONE }\end{array}$ & OTHER \\
\hline $\mathrm{N}$ & 152 & 63 & 3 & 23 & 12 & 1 & 17 & 0 \\
\hline
\end{tabular}

Mean $=2.148$, S.D. $=1.911$ 
All categories were compared to the total population using the chi square statistic for Question number 13 with the following results.

TABLE NUMBER 56

CHI SQUARE RESULTS FOR QUESTION NUMBER 13

ASSUMPTION OF LEADERSHIP ROLE

\begin{tabular}{|l|c|c|c|}
\hline CATEGORY & CHI SQ. VALUE & $\begin{array}{c}\text { DEGREES } \\
\text { FREEDOM }\end{array}$ & PROBABILITY \\
\hline School Size & 9.750 & 12 & .638 \\
\hline $\begin{array}{l}\text { Role of } \\
\text { Resp. }\end{array}$ & 28.544 & 36 & .807 \\
\hline Longevity & 29.172 & 30 & .509 \\
\hline Attendance & 6.058 & 18 & .996 \\
\hline Training & 1.720 & 6 & .945 \\
\hline District Size & 9.951 & 12 & .620 \\
\hline
\end{tabular}

According to the chi square statistic and the .05 test, none of the categories

exhibited a significant deviation from the total population for Question \# 13.

QUESTION \# 14: Most of the ideas expressed in our School Improvement

Council meetings appear to come from: (select only one). The choices for this question were the same as Question \# 13. Whereas no one selected "other" in Question \# 13, a substantial percentage chose this answer for Question \# 14 and 
entered a handwritten notation that implied ideas came from all members of the council. The following table exhibits the responses to Question \# 14. 
TABLE NUMBER 57

TOTAL GROUP RESPONSE SUMMARY TO QUESTION NUMBER 14

INDIVIDUAL ORIGINATING MOST IDEAS

\begin{tabular}{|c|c|c|c|c|c|c|c|c|}
\hline $\begin{array}{c}\text { RESPONS } \\
\mathrm{E}\end{array}$ & PRINCIPA & TEACHE & $\begin{array}{c}\text { SERVICE } \\
\text { PERSONNE } \\
\mathrm{L}\end{array}$ & $\begin{array}{c}\text { PAREN } \\
\mathrm{T}\end{array}$ & $\begin{array}{c}\text { AT- } \\
\text { LARGE } \\
\text { MEMBER }\end{array}$ & $\begin{array}{c}\text { STUDENT } \\
\text { NO }\end{array}$ & $\begin{array}{c}\text { OTHER } \\
\mathrm{E}\end{array}$ & $\begin{array}{c}\text { ONHE } \\
\mathrm{N}\end{array}$ \\
\hline
\end{tabular}

Mean $=3.554$, S.D. $=2.756$ 
All categories were compared to the total population using the chi square statistic for Question \# 14 with the following results.

\section{TABLE NUMBER 58}

CHI SQUARE RESULTS FOR QUESTION NUMBER 14

INDIVIDUAL ORIGINATING MOST IDEAS

\begin{tabular}{|l|c|c|c|}
\hline \multicolumn{1}{|c|}{ CATEGORY } & CHI SQ. VALUE & $\begin{array}{c}\text { DEGREES } \\
\text { FREEDOM }\end{array}$ & PROBABILITY \\
\hline School Size & 11.132 & 14 & .676 \\
\hline Role of Resp. & 112.633 & 42 & .000 \\
\hline Longevity & 36.092 & 35 & .420 \\
\hline Attendance & 16.839 & 21 & .721 \\
\hline Training & 11.871 & 7 & .105 \\
\hline District Size & 17.095 & 14 & .251 \\
\hline
\end{tabular}

The statistics indicate the category role of respondent has a significant deviation when compared to the total population using the .05 test. The results of this category are listed in the following table. 
TABLE NUMBER 59

QUESTION NUMBER 14 RESPONSES BY ROLE OF RESPONDENT

INDIVIDUAL ORIGINATING MOST IDEAS

\begin{tabular}{|l|c|c|c|c|c|c|c|}
\hline RESPONSE & PRINCIPAL & TEACHER & $\begin{array}{c}\text { SERVICE } \\
\text { PERSONNEL }\end{array}$ & PARENT & $\begin{array}{c}\text { AT- } \\
\text { LARGE } \\
\text { MEMBER }\end{array}$ & STUDENT & $\begin{array}{c}\text { NO } \\
\text { ONE }\end{array}$ \\
\hline Principal & 6 & 37 & 16 & 17 & 5 & 5 & 0 \\
\hline Teacher & 10 & 34 & 7 & 9 & 4 & 2 & 0 \\
\hline Service Per. & 0 & 1 & 0 & 0 & 0 & 0 & 1 \\
\hline Parent & 7 & 12 & 2 & 7 & 1 & 0 & 3 \\
\hline At-Large & 3 & 6 & 5 & 0 & 0 & 1 & 0 \\
\hline Student & 0 & 1 & 0 & 0 & 0 & 0 & 1 \\
\hline No One & 0 & 0 & 2 & 0 & 0 & 0 & 0 \\
\hline Other & 17 & 12 & 18 & 11 & 2 & 2 & 0 \\
\hline MEAN & 4.767 & 2.796 & 4.420 & 3.431 & 2.750 & 3.000 & 4.200 \\
\hline S.D. & 8.183 & 5.125 & 9.677 & 8.391 & 6.750 & 8.444 & 1.200 \\
\hline
\end{tabular}


School Improvement Council's Work Defined

By Respondent's Perceptions

Question \# 15 asked the respondents to list the five major

accomplishments of their school's School Improvement Council. The researcher categorized their responses into general categories and listed them in the following table.

TABLE NUMBER 60

SUMMARY OF RESPONSES TO QUESTION NUMBER 15

MAJOR ACCOMPLISHMENTS

\begin{tabular}{|l|c|}
\hline \multicolumn{1}{|c|}{ COMMENT } & NUMBER \\
\hline Safety Programs/Facilities Improvement & 180 \\
\hline Student Oriented Programs and Policies Developed & 99 \\
\hline $\begin{array}{l}\text { Communication/Coordination/Involvement With } \\
\text { Business/Parents/Community }\end{array}$ & 59 \\
\hline Curriculum Changes/Improvements & 44 \\
\hline Obtained Waivers From State/Local Boards & 24 \\
\hline Technology Upgrades & 20 \\
\hline Miscellaneous Programs & 18 \\
\hline School Organizational Improvements & 16 \\
\hline Satellite Programs For Students & 15 \\
\hline LSIC Organizational Improvements & \\
\hline
\end{tabular}




\begin{tabular}{|l|c|}
\hline \multicolumn{1}{|c|}{ COMMENT } & NUMBER \\
\hline School of Excellence/Blue Ribbon Awards & 13 \\
\hline Secured Additional Staffing & 13 \\
\hline Grants Obtained & 10 \\
\hline Satellite Programs/Dinners for Adults & 9 \\
\hline Local Board of Education Presentations/Interactions & 8 \\
\hline Entertainment & 7 \\
\hline SBA/Levy Proposals & 7 \\
\hline Library Materials Furnished & 6 \\
\hline Improved Volunteer Involvement & 6 \\
\hline Fund Raising & 5 \\
\hline In-School Clinics Provided & 5 \\
\hline Student Yearbook/Newspaper Created & 4 \\
\hline Attendance Improvement & 2 \\
\hline Counseling Improvement & 2 \\
\hline Training Provided & 1 \\
\hline Teaching Materials Provided & 1 \\
\hline
\end{tabular}

Question \# 16 asked the respondents to list the two major strengths of their School Improvement Council. Again, responses were put into general categories and listed in the following table. 
TABLE NUMBER 61

SUMMARY OF RESPONSES FOR QUESTION NUMBER 16

MAJOR STRENGTHS

\begin{tabular}{|l|c|}
\hline \multicolumn{1}{|c|}{ COMMENT } & NUMBER \\
\hline Harmony Among Members & 70 \\
\hline $\begin{array}{l}\text { Increasing Involvement/Participation/Volunteer } \\
\text { Programs }\end{array}$ & 64 \\
\hline Organizational Improvements & 32 \\
\hline Student Programs & 20 \\
\hline Improved Communications & 19 \\
\hline Improved Partnerships & 17 \\
\hline Physical Plant Improvements & 16 \\
\hline Strong Leadership & 14 \\
\hline Student Concerns & 9 \\
\hline Strong Membership Attendance & 8 \\
\hline Strong Student Member Representation & 7 \\
\hline Curriculum Improvements & 7 \\
\hline Diversity Among Members & 6 \\
\hline Tutoring/Mentoring Programs & 5 \\
\hline Providing Needed Materials/Services & 5 \\
\hline Increased School Pride & 4 \\
\hline Obtaining Funding/Grants & 4 \\
\hline Providing Awards/Dinners & 2 \\
\hline
\end{tabular}




\begin{tabular}{|l|c|}
\hline \multicolumn{1}{|c|}{ COMMENT } & NUMBER \\
\hline Policy Revisions & 1 \\
\hline School Cleanliness & 1 \\
\hline
\end{tabular}

Question \# 17 asked the respondents to list the two major weaknesses of their School Improvement Council. Many of the respondents chose to leave this question blank, either not wanting to admit the council had any weaknesses or believing they had none. General categories were created and the responses are listed in the following table.

TABLE NUMBER 62

SUMMARY OF RESPONSES TO QUESTION NUMBER 17

MAJOR WEAKNESSES

\begin{tabular}{|l|c|}
\hline \multicolumn{1}{|c|}{ COMMENT } & NUMBER \\
\hline Lack of Member's Response/Interest/Participation & 84 \\
\hline Lack of Leadership & 34 \\
\hline Lack of Business Support & 32 \\
\hline Convenient Meeting Times/Durations & 27 \\
\hline Lack of Training & 24 \\
\hline Proper Funding & 20 \\
\hline Too Many Non-Academic Concerns & 19 \\
\hline Lack of Local Board of Education Recognition & 17 \\
\hline
\end{tabular}




\begin{tabular}{|l|c|}
\hline \multicolumn{1}{|c|}{ COMMENT } & NUMBER \\
\hline Lack of Communication & 11 \\
\hline Lack of Proper Attitude & 9 \\
\hline
\end{tabular}

Respondent's Perceptions of Changes Produced by School Improvement Councils

In an effort to recognize any school reform based on the creation of school improvement councils, questions numbering 18 through 25 were designed to reflect changes in the school system. Once again, a Likert scale was used to represent the responses. Significantly was numbered one (1), very much was numbered two (2), moderately was numbered three (3), somewhat was numbered four (4), and not at all was numbered five (5). The response "don't know" was ignored throughout this survey in all statistical computation.

QUESTION \# 18: To what extent has the operation of the school improvement council improved the quality of teacher performance at your school? 
TABLE NUMBER 63

TOTAL GROUP SUMMARY FOR QUESTION NUMBER 18

IMPROVEMENT OF QUALITY OF TEACHER PERFORMANCE

\begin{tabular}{|c|c|c|c|c|c|c|}
\hline RESPONSE & SIGNIFICANT & $\begin{array}{c}\text { VERY } \\
\text { MUCH }\end{array}$ & MODERATELY & $\begin{array}{c}\text { SOME } \\
\text { WHAT }\end{array}$ & $\begin{array}{c}\text { NOT } \\
\text { AT } \\
\text { ALL }\end{array}$ & $\begin{array}{c}\text { DON'T } \\
\text { KNOW }\end{array}$ \\
\hline $\mathrm{N}$ & 4 & 39 & 85 & 64 & 51 & 18 \\
\hline
\end{tabular}

Mean $=3.662$, S.D. $=1.193$

All categories were compared to the total population using the chi square statistic for Question \# 18 with the following results.

TABLE NUMBER 64

CHI SQUARE RESULTS FOR QUESTION NUMBER 18

IMPROVEMENT OF QUALITY OF TEACHER PERFORMANCE

\begin{tabular}{|l|c|c|c|}
\hline \multicolumn{1}{|c|}{ CATEGORY } & CHI SQ. VALUE & $\begin{array}{c}\text { DEGREES } \\
\text { FREEDOM }\end{array}$ & PROBABILITY \\
\hline School Size & 8.205 & 10 & .609 \\
\hline Role of Resp. & 38.970 & 30 & .126 \\
\hline Longevity & 37.197 & 25 & .055 \\
\hline Attendance & 16.103 & 15 & .375 \\
\hline Training & 18.763 & 5 & .002 \\
\hline District Size & 15.967 & 10 & .101 \\
\hline
\end{tabular}


The statistics indicate the category training shows a significant deviation when compared to the total population using the .05 test. The results from this category are listed in the following table.

TABLE NUMBER 65

QUESTION NUMBER 18 RESPONSES BY TRAINING

IMPROVEMENT OF QUALITY OF TEACHER PERFORMANCE

\begin{tabular}{|l|c|c|}
\hline \multicolumn{1}{|c|}{ RESPONSE } & YES & NO \\
\hline Significantly & 3 & 32 \\
\hline Very Much & 7 & 58 \\
\hline Moderately & 27 & 48 \\
\hline Somewhat & 15 & 47 \\
\hline Not At All & 4 & 16 \\
\hline Don't Know & 2 & 3.580 \\
\hline MEAN & 3.178 & 1.112 \\
\hline S.D. & .846 & 1 \\
\hline
\end{tabular}

QUESTION \# 19: To what extent has the operation of the school improvement council improved the quality of service personnel performance in your school? 
TABLE NUMBER 66

TOTAL GROUP RESPONSE SUMMARY FOR QUESTION \# 19

IMPROVED QUALITY OF SERVICE PERSONNEL PERFORMANCE

\begin{tabular}{|c|c|c|c|c|c|c|}
\hline RESPONSE & SIGNIFICANTLY & $\begin{array}{c}\text { VERY } \\
\text { MUCH }\end{array}$ & MODERATELY & $\begin{array}{c}\text { SOME } \\
\text { WHAT }\end{array}$ & $\begin{array}{c}\text { NOT } \\
\text { AT } \\
\text { ALL }\end{array}$ & $\begin{array}{c}\text { DON'T } \\
\text { KNOW }\end{array}$ \\
\hline $\mathrm{N}$ & 3 & 22 & 76 & 61 & 74 & 27 \\
\hline
\end{tabular}

Mean $=3.996$, S.D. $=1.193$

All categories were compared to the total population using the chi square statistic for Question \# 19 with the following results.

\section{TABLE NUMBER 67}

CHI SQUARE RESULTS FOR QUESTION NUMBER 19

IMPROVED QUALITY OF SERVICE PERSONNEL PERFORMANCE

\begin{tabular}{|l|c|c|c|}
\hline \multicolumn{1}{|c|}{ CATEGORY } & CHI SQ. VALUE & $\begin{array}{c}\text { DEGREES } \\
\text { FREEDOM }\end{array}$ & PROBABILITY \\
\hline School Size & 12.619 & 10 & .246 \\
\hline Role of Resp. & 37.005 & 30 & .177 \\
\hline Longevity & 19.866 & 25 & .754 \\
\hline Attendance & 9.940 & 15 & .824 \\
\hline Training & 10.268 & 5 & .068 \\
\hline District Size & 14.569 & 10 & .149 \\
\hline
\end{tabular}


The statistics indicate, using a .05 test, that none of the categories exhibited significant deviation when compared to the total population.

QUESTION \# 20: To what extent has the operation of the school improvement council improved the quality of student performance as measured by standardized test performance in your school?

TABLE NUMBER 68

GROUP RESPONSE SUMMARY TO QUESTION NUMBER 20 IMPROVED QUALITY OF STUDENT PERFORMANCE

\begin{tabular}{|c|c|c|c|c|c|c|}
\hline RESPONSE & SIGNIFICANT & $\begin{array}{c}\text { VERY } \\
\text { MUCH }\end{array}$ & MODERATELY & $\begin{array}{c}\text { SOME } \\
\text { WHAT }\end{array}$ & $\begin{array}{c}\text { NOT } \\
\text { AT } \\
\text { ALL }\end{array}$ & $\begin{array}{c}\text { DON'T } \\
\text { KNOW }\end{array}$ \\
\hline $\mathrm{N}$ & 20 & 45 & 72 & 69 & 36 & 24 \\
\hline
\end{tabular}

Mean $=3.481$, S.D. $=1.363$

All categories were compared to the total population using the chi square statistic for Question \# 20 with the following results. 
TABLE NUMBER 69

CHI SQUARE RESULTS FOR QUESTION NUMBER 20

IMPROVED QUALITY OF STUDENT PERFORMANCE

\begin{tabular}{|l|c|c|c|}
\hline \multicolumn{1}{|c|}{ CATEGORY } & CHI SQ. VALUE & $\begin{array}{c}\text { DEGREES } \\
\text { FREEDOM }\end{array}$ & PROBABILITY \\
\hline School Size & 12.234 & 10 & .270 \\
\hline Role of Resp. & 31.622 & 30 & .853 \\
\hline Longevity & 48.731 & 25 & .003 \\
\hline Attendance & 17.989 & 15 & .263 \\
\hline Training & 18.122 & 5 & .003 \\
\hline District Size & 12.211 & 10 & .271 \\
\hline
\end{tabular}

The statistics indicate the categories longevity and training show significant deviation when compared to the total population using the .05 test. The results of these categories are listed in the following tables. 
TABLE NUMBER 70

QUESTION NUMBER 20 RESPONSES BY LONGEVITY

IMPROVED QUALITY OF STUDENT PERFORMANCE

\begin{tabular}{|l|c|c|c|c|c|}
\hline RESPONSE & 1 YR & 2 YRS. & 3 YRS. & 4 YRS. & 5+ YRS. \\
\hline Significantly & 5 & 5 & 2 & 2 & 5 \\
\hline Very much & 8 & 11 & 10 & 1 & 15 \\
\hline Moderately & 11 & 21 & 11 & 10 & 17 \\
\hline Somewhat & 17 & 16 & 9 & 11 & 13 \\
\hline Not At All & 6 & 11 & 6 & 4 & 7 \\
\hline Don't Know & 17 & 4 & 2 & 1 & 0 \\
\hline MEAN & 3.234 & 3.265 & 3.184 & 3.500 & 3.625 \\
\hline S.D. & 1.054 & 1.291 & 1.275 & 1.036 & 1.356 \\
\hline
\end{tabular}


TABLE NUMBER 71

QUESTION NUMBER 20 RESPONSES BY TRAINING

IMPROVED QUALITY OF STUDENT PERFORMANCE

\begin{tabular}{|l|c|c|}
\hline \multicolumn{1}{|c|}{ RESPONSE } & YES & NO \\
\hline Significantly & 9 & 10 \\
\hline Very Much & 11 & 34 \\
\hline Moderately & 20 & 52 \\
\hline Somewhat & 14 & 55 \\
\hline Not At All & 4 & 32 \\
\hline Don't Know & 0 & 24 \\
\hline MEAN & 3.017 & 3.355 \\
\hline S.D. & 1.355 & 1.135 \\
\hline
\end{tabular}

QUESTION \# 21: To what extent has the operation of the school improvement council increased the involvement of parents in the decision-making process at your school? 
TABLE NUMBER 72

GROUP RESPONSE SUMMARY OF QUESTION NUMBER 21

INVOLVEMENT OF PARENTS INCREASED

\begin{tabular}{|c|c|c|c|c|c|c|}
\hline RESPONSE & SIGNIFICANTLY & $\begin{array}{c}\text { VERY } \\
\text { MUCH }\end{array}$ & MODERATELY & $\begin{array}{c}\text { SOME } \\
\text { WHAT }\end{array}$ & $\begin{array}{c}\text { NOT } \\
\text { AT } \\
\text { ALL }\end{array}$ & $\begin{array}{c}\text { DON’T } \\
\text { KNOW }\end{array}$ \\
\hline $\mathrm{N}$ & 11 & 84 & 78 & 58 & 26 & 9 \\
\hline
\end{tabular}

Mean $=3.117$, S.D. $=1.177$

All categories were compared to the total population using the chi square statistic for Question \# 21 with the following results.

TABLE NUMBER 73

CHI SQUARE RESULTS FOR QUESTION NUMBER 21

INVOLVEMENT OF PARENTS INCREASED

\begin{tabular}{|l|c|c|c|}
\hline \multicolumn{1}{|c|}{ CATEGORY } & CHI SQ. VALUE & $\begin{array}{c}\text { DEGREES } \\
\text { FREEDOM }\end{array}$ & PROBABILITY \\
\hline School Size & 12.552 & 10 & .250 \\
\hline Role of Resp. & 43.026 & 30 & .058 \\
\hline Longevity & 30.578 & 25 & .203 \\
\hline Attendance & 16.251 & 15 & .366 \\
\hline Training & 17.678 & 5 & .003 \\
\hline District Size & 20.615 & 10 & .024 \\
\hline
\end{tabular}


The statistics indicate the categories training and district size show significant deviation when compared to the total population using the .05 test. The results are listed in the following tables.

TABLE NUMBER 74

QUESTION NUMBER 21 RESPONSES BY TRAINING

INVOLVEMENT OF PARENTS INCREASED

\begin{tabular}{|l|c|c|}
\hline \multicolumn{1}{|c|}{ RESPONSE } & YES & NO \\
\hline Significantly & 6 & 5 \\
\hline Very Much & 26 & 58 \\
\hline Moderately & 16 & 61 \\
\hline Somewhat & 9 & 49 \\
\hline Not At All & 2 & 9 \\
\hline Don't Know & 0 & 9.096 \\
\hline MEAN & 2.576 & 1.070 \\
\hline S.D. & .973 & \\
\hline
\end{tabular}


TABLE NUMBER 75

QUESTION NUMBER 21 RESPONSES BY DISTRICT SIZE

INVOLVEMENT OF PARENTS INCREASED

\begin{tabular}{|l|c|c|c|}
\hline \multicolumn{1}{|c|}{ RESPONSE } & SMALL & MEDIUM & LARGE \\
\hline Significantly & 1 & 4 & 6 \\
\hline Very Much & 31 & 20 & 33 \\
\hline Moderately & 25 & 34 & 18 \\
\hline Somewhat & 14 & 27 & 17 \\
\hline Not At All & 11 & 12 & 3 \\
\hline Don't Know & 4 & 3 & 2 \\
\hline MEAN & 3.037 & 3.134 & 2.714 \\
\hline S.D. & 1.093 & 1.077 & 1.022 \\
\hline
\end{tabular}

QUESTION \# 22: To what extent has the operation of the school improvement council increased the involvement of business leaders in the decision-making process at your school? 
TABLE NUMBER 76

TOTAL GROUP RESPONSE SUMMARY FOR QUESTION NUMBER 22

INVOLVEMENT OF BUSINESS LEADERS INCREASED

\begin{tabular}{|c|c|c|c|c|c|c|}
\hline RESPONSE & SIGNIFICANTLY & $\begin{array}{c}\text { VERY } \\
\text { MUCH }\end{array}$ & MODERATELY & $\begin{array}{c}\text { SOME } \\
\text { WHAT }\end{array}$ & $\begin{array}{c}\text { NOT } \\
\text { AT } \\
\text { ALL }\end{array}$ & $\begin{array}{c}\text { DON'T } \\
\text { KNOW }\end{array}$ \\
\hline $\mathrm{N}$ & 11 & 61 & 66 & 77 & 35 & 15 \\
\hline
\end{tabular}

Mean $=3.411$, S.D. $=1.250$

All categories were compared to the total population using the chi square statistic for Question \# 22 with the following results.

TABLE NUMBER 77

CHI SQUARE RESULTS FOR QUESTION NUMBER 22

INVOLVEMENT OF BUSINESS LEADERS INCREASED

\begin{tabular}{|l|c|c|c|}
\hline \multicolumn{1}{|c|}{ CATEGORY } & CHI SQ. VALUE & $\begin{array}{c}\text { DEGREES } \\
\text { FREEDOM }\end{array}$ & PROBABILITY \\
\hline School Size & 9.389 & 10 & .496 \\
\hline Role of Resp. & 44.881 & 30 & .040 \\
\hline Longevity & 45.370 & 25 & .008 \\
\hline Attendance & 30.013 & 15 & .012 \\
\hline Training & 16.840 & 5 & .005 \\
\hline District Size & 15.473 & 10 & .116 \\
\hline
\end{tabular}


The statistics indicate categories role of respondent, longevity, attendance, and training show significant deviation when compared to the total population using the .05 test. The results of these categories are listed in the following tables.

\section{TABLE NUMBER 78}

\section{QUESTION NUMBER 22 RESPONSES BY LONGEVITY}

INVOLVEMENT OF BUSINESS LEADERS INCREASED

\begin{tabular}{|l|c|c|c|c|c|}
\hline RESPONSE & 1 YR. & 2 YRS. & 3 YRS. & 4 YRS. & 5+ YRS. \\
\hline Significantly & 4 & 4 & 1 & 2 & 0 \\
\hline Very Much & 11 & 9 & 14 & 8 & 16 \\
\hline Moderately & 14 & 21 & 12 & 4 & 14 \\
\hline Somewhat & 17 & 18 & 11 & 7 & 21 \\
\hline Not At All & 8 & 13 & 1 & 6 & 6 \\
\hline Don't Know & 11 & 2 & 1 & 1 & 0 \\
\hline MEAN & 3.259 & 3.415 & 2.923 & 3.259 & 3.298 \\
\hline S.D. & 1.131 & 1.270 & .840 & 1.674 & .999 \\
\hline
\end{tabular}


TABLE NUMBER 79

\section{QUESTION NUMBER 22 RESPONSES BY ROLE OF RESPONDENT}

INVOLVEMENT OF BUSINESS LEADERS INCREASED

\begin{tabular}{|l|c|c|c|c|c|c|c|}
\hline RESPONSE & PRINCIPAL & TEACHER & $\begin{array}{c}\text { SERVICE } \\
\text { PERSONNEL }\end{array}$ & PARENT & $\begin{array}{c}\text { AT-LARGE } \\
\text { MEMBER }\end{array}$ & $\begin{array}{c}\text { AT-LARGE } \\
\text { MEMBER, } \\
\text { BUSINESS }\end{array}$ & STUDENT \\
\hline Significantly & 0 & 5 & 2 & 4 & 0 & 0 & 0 \\
\hline Very Much & 12 & 24 & 12 & 6 & 5 & 1 & 1 \\
\hline Moderately & 11 & 25 & 17 & 7 & 2 & 3 & 1 \\
\hline Somewhat & 17 & 28 & 12 & 14 & 3 & 2 & 1 \\
\hline Not At All & 4 & 16 & 2 & 10 & 1 & 2 & 0 \\
\hline Don't Know & 0 & 3 & 5 & 2 & 1 & 2 & 2 \\
\hline MEAN & 3.295 & 3.275 & 2.733 & 3.487 & 3.000 & 3.625 & 3.000 \\
\hline S.D. & .957 & 1.291 & .882 & 1.577 & .818 & .875 & .500 \\
\hline
\end{tabular}




\section{TABLE NUMBER 80}

QUESTION NUMBER 22 RESPONSES BY ATTENDANCE INVOLVEMENT OF BUSINESS LEADERS INCREASED

\begin{tabular}{|l|c|c|c|c|}
\hline RESPONSE & EVERY & MOST & FEW & NEVER \\
\hline Significantly & 8 & 2 & 0 & 1 \\
\hline Very Much & 43 & 15 & 1 & 0 \\
\hline Moderately & 38 & 25 & 3 & 0 \\
\hline Somewhat & 49 & 25 & 2 & 0 \\
\hline Not At All & 26 & 9 & 0 & 0 \\
\hline Don't Know & 10 & 5 & 0 & 0 \\
\hline MEAN & 3.256 & 3.315 & 3.166 & 1.000 \\
\hline S.D. & 1.256 & .955 & .567 & 0 \\
\hline
\end{tabular}


TABLE NUMBER 81

QUESTION NUMBER 22 RESPONSE BY TRAINING

INVOLVEMENT OF BUSINESS LEADERS INCREASED

\begin{tabular}{|l|c|c|}
\hline \multicolumn{1}{|c|}{ RESPONSE } & YES & NO \\
\hline Significantly & 4 & 7 \\
\hline Very Much & 23 & 38 \\
\hline Moderately & 13 & 53 \\
\hline Somewhat & 11 & 65 \\
\hline Not At All & 8 & 27 \\
\hline Don't Know & 0 & 15 \\
\hline MEAN & 2.932 & 3.352 \\
\hline S.D. & 1.409 & 1.056 \\
\hline
\end{tabular}

QUESTION \# 23: To what extent has the operation of the school improvement council increased the involvement of students in the decision-making process at your school? 
TABLE NUMBER 82

TOTAL GROUP RESPONSE SUMMARY FOR QUESTION NUMBER 23

INVOLVEMENT OF STUDENTS INCREASED

\begin{tabular}{|c|c|c|c|c|c|c|}
\hline RESPONSE & SIGNIFICANTLY & $\begin{array}{c}\text { VERY } \\
\text { MUCH }\end{array}$ & MODERATELY & $\begin{array}{c}\text { SOME } \\
\text { WHAT }\end{array}$ & $\begin{array}{c}\text { NOT } \\
\text { AT } \\
\text { ALL }\end{array}$ & $\begin{array}{c}\text { DON'T } \\
\text { KNOW }\end{array}$ \\
\hline $\mathrm{N}$ & 4 & 26 & 75 & 76 & 66 & 19 \\
\hline
\end{tabular}

Mean $=3.868$, S.D. $=1.153$

All categories were compared to the total population using the chi square statistic for Question \# 23 with the following results.

TABLE NUMBER 83

CHI SQUARE RESULTS FOR QUESTION NUMBER 23

INVOLVEMENT OF STUDENTS INCREASED

\begin{tabular}{|l|c|c|c|}
\hline \multicolumn{1}{|c|}{ CATEGORY } & CHI SQ. VALUE & $\begin{array}{c}\text { DEGREES } \\
\text { FREEDOM }\end{array}$ & PROBABILITY \\
\hline School Size & 11.656 & 10 & .309 \\
\hline Role of Resp. & 62.630 & 30 & .000 \\
\hline Longevity & 17.807 & 25 & .850 \\
\hline Attendance & 23.210 & 15 & .080 \\
\hline Training & 11.841 & 5 & .037 \\
\hline District Size & 10.177 & 10 & .425 \\
\hline
\end{tabular}


The statistics indicate the categories role of respondent and training show a significant deviation when compared to the total population using the .05 test. The results from these categories are listed in the following tables.

TABLE NUMBER 84

QUESTION NUMBER 23 RESPONSE BY TRAINING INVOLVEMENT OF STUDENTS INCREASED

\begin{tabular}{|l|c|c|}
\hline \multicolumn{1}{|c|}{ RESPONSE } & YES & NO \\
\hline Significantly & 1 & 3 \\
\hline Very Much & 10 & 16 \\
\hline Moderately & 22 & 63 \\
\hline Somewhat & 11 & 52 \\
\hline Not At All & 14 & 18 \\
\hline Don't Know & 1 & 3.776 \\
\hline MEAN & 3.465 & .808 \\
\hline S.D., & 1.180 & 64 \\
\hline
\end{tabular}


TABLE NUMBER 85

QUESTION NUMBER 23 RESPONSES BY ROLE OF RESPONDENT

INVOLVEMENT OF STUDENTS INCREASED

\begin{tabular}{|l|c|c|c|c|c|c|c|}
\hline RESPONSE & PRINCIPAL & TEACHER & $\begin{array}{c}\text { SERVICE } \\
\text { PERSONNEL }\end{array}$ & PARENT & $\begin{array}{c}\text { AT-LARGE } \\
\text { MEMBER }\end{array}$ & $\begin{array}{c}\text { AT-LARGE } \\
\text { MEMBER, } \\
\text { BUSINESS }\end{array}$ & STUDENT \\
\hline Significantly & 1 & 1 & 0 & 2 & 0 & 0 & 0 \\
\hline Very Much & 4 & 9 & 6 & 3 & 2 & 0 & 2 \\
\hline Moderately & 11 & 25 & 25 & 8 & 1 & 3 & 2 \\
\hline Somewhat & 17 & 33 & 7 & 16 & 2 & 0 & 1 \\
\hline Not At All & 11 & 27 & 7 & 14 & 4 & 3 & 0 \\
\hline Don't Know & 0 & 6 & 6 & 1 & 2 & 4 & 0 \\
\hline MEAN & 3.750 & 3.800 & 3.333 & 3.860 & 3.888 & 4.000 & 2.000 \\
\hline S.D. & 1.029 & .932 & .720 & 1.190 & 1.289 & .667 & .500 \\
\hline
\end{tabular}

QUESTION \# 24: To what extent has the operation of the school improvement 
council increased the involvement of service personnel in the decision-making process at your school?

TABLE NUMBER 86

TOTAL GROUP RESPONSE SUMMARY FOR QUESTION NUMBER 24 INVOLVEMENT OF SERVICE PERSONNEL INCREASED

\begin{tabular}{|c|c|c|c|c|c|c|}
\hline RESPONSE & SIGNIFICANTLY & $\begin{array}{c}\text { VERY } \\
\text { MUCH }\end{array}$ & MODERATELY & $\begin{array}{c}\text { SOME } \\
\text { WHAT }\end{array}$ & $\begin{array}{c}\text { NOT } \\
\text { AT } \\
\text { ALL }\end{array}$ & $\begin{array}{c}\text { DON'T } \\
\text { KNOW }\end{array}$ \\
\hline $\mathrm{N}$ & 6 & 42 & 81 & 82 & 29 & 27 \\
\hline
\end{tabular}

Mean $=3.625$, S.D. $=1.230$

All categories were compared to the total population using the chi square statistic for Question \# 24 with the following results. 
TABLE NUMBER 87

CHI SQUARE RESULTS FOR QUESTION NUMBER 24

INVOLVEMENT OF SERVICE PERSONNEL INCREASED

\begin{tabular}{|l|c|c|c|}
\hline \multicolumn{1}{|c|}{ CATEGORY } & CHI SQ. VALUE & $\begin{array}{c}\text { DEGREES } \\
\text { FREEDOM }\end{array}$ & PROBABILITY \\
\hline School Size & 15.854 & 10 & .104 \\
\hline Role of Resp. & 61.461 & 30 & .000 \\
\hline Longevity & 27.750 & 25 & .320 \\
\hline Attendance & 16.747 & 15 & .334 \\
\hline Training & 13.026 & 5 & .023 \\
\hline District Size & 13.718 & 10 & .186 \\
\hline
\end{tabular}

The statistics indicate the categories role of respondent and training show a significant deviation when compared to the total population using the .05 test. The results from these categories are listed in the following tables. 
TABLE NUMBER 88

QUESTION NUMBER 24 RESPONSES BY TRAINING

INVOLVEMENT OF SERVICE PERSONNEL INCREASED

\begin{tabular}{|l|c|c|}
\hline \multicolumn{1}{|c|}{ RESPONSE } & YES & NO \\
\hline Significantly & 3 & 3 \\
\hline Very Much & 13 & 29 \\
\hline Moderately & 21 & 59 \\
\hline Somewhat & 18 & 64 \\
\hline Not At All & 3 & 26 \\
\hline Don't Know & 1 & 26 \\
\hline MEAN & 3.086 & 3.447 \\
\hline S.D. & .941 & .839 \\
\hline
\end{tabular}


TABLE NUMBER 89

\section{QUESTION NUMBER 24 RESPONSES BY ROLE OF RESPONDENT}

INVOLVEMENT OF SERVICE PERSONNEL INCREASED

\begin{tabular}{|l|c|c|c|c|c|c|c|}
\hline RESPONSE & PRINCIPAL & TEACHER & $\begin{array}{c}\text { SERVICE } \\
\text { PERSONNEL }\end{array}$ & PARENT & $\begin{array}{c}\text { AT-LARGE } \\
\text { MEMBER }\end{array}$ & $\begin{array}{c}\text { AT-LARGE } \\
\text { MEMBER, } \\
\text { BUSINESS }\end{array}$ & STUDENT \\
\hline Significantly & 1 & 1 & 2 & 2 & 0 & 0 & 0 \\
\hline Very Much & 7 & 14 & 11 & 6 & 2 & 1 & 1 \\
\hline Moderately & 15 & 38 & 14 & 6 & 4 & 2 & 2 \\
\hline Somewhat & 19 & 32 & 15 & 13 & 2 & 0 & 1 \\
\hline Not At All & 2 & 10 & 5 & 10 & 1 & 1 & 0 \\
\hline Don't Know & 0 & 6 & 4 & 7 & 3 & 6 & 1 \\
\hline MEAN & 3.318 & 3.378 & 3.212 & 3.621 & 3.222 & 3.250 & 3.000 \\
\hline S.D. & .780 & .764 & 1.037 & 1.226 & .687 & .528 & .500 \\
\hline
\end{tabular}


QUESTION \# 25: To what extent has the operation of the school improvement council increased the involvement of teachers in the decision-making process at your school?

TABLE NUMBER 90

TOTAL GROUP RESPONSE SUMMARY FOR QUESTION NUMBER 25 INVOLVEMENT OF TEACHERS INCREASED

\begin{tabular}{|c|c|c|c|c|c|c|}
\hline RESPONSE & SIGNIFICANTLY & $\begin{array}{c}\text { VERY } \\
\text { MUCH }\end{array}$ & MODERATELY & $\begin{array}{c}\text { SOME } \\
\text { WHAT }\end{array}$ & $\begin{array}{c}\text { NOT } \\
\text { AT } \\
\text { ALL }\end{array}$ & $\begin{array}{c}\text { DON'T } \\
\text { KNOW }\end{array}$ \\
\hline $\mathrm{N}$ & 20 & 75 & 82 & 63 & 14 & 13 \\
\hline
\end{tabular}

Mean $=3.056$, S.D. $=1.211$

All categories were compared to the total population using the chi square statistic for Question \# 25 with the following results. 
TABLE NUMBER 91

CHI SQUARE RESULTS FOR QUESTION NUMBER 25

INVOLVEMENT OF TEACHERS INCREASED

\begin{tabular}{|l|c|c|c|}
\hline \multicolumn{1}{|c|}{ CATEGORY } & CHI SQ. VALUE & $\begin{array}{c}\text { DEGREES } \\
\text { FREEDOM }\end{array}$ & PROBABILITY \\
\hline School Size & 19.743 & 10 & .032 \\
\hline Role of Resp. & 46.482 & 30 & .028 \\
\hline Longevity & 46.129 & 25 & .006 \\
\hline Attendance & 24.060 & 15 & .064 \\
\hline Training & 9.889 & 5 & .078 \\
\hline District Size & 19.667 & 10 & .033 \\
\hline
\end{tabular}

The statistics indicate the categories role of respondent, school size, longevity, and district size show significant deviation when compared to the total population using the .05 test. The results from these categories are listed in the following tables. 
TABLE NUMBER 92

QUESTION NUMBER 25 RESPONSES BY SCHOOL SIZE

INVOLVEMENT OF TEACHERS INCREASED

\begin{tabular}{|l|c|c|c|}
\hline \multicolumn{1}{|c|}{ RESPONSE } & SMALL & MEDIUM & LARGE \\
\hline Significantly & 12 & 3 & 5 \\
\hline Very Much & 30 & 20 & 25 \\
\hline Moderately & 19 & 29 & 34 \\
\hline Somewhat & 16 & 25 & 22 \\
\hline Not At All & 6 & 6 & 2 \\
\hline Don't Know & 3 & 7 & 3 \\
\hline MEAN & 2.686 & 3.132 & 2.897 \\
\hline S.D. & 1.292 & .894 & .823 \\
\hline
\end{tabular}


TABLE NUMBER 93

QUESTION NUMBER 25 RESPONSES BY ROLE OF RESPONDENT

INVOLVEMENT OF TEACHERS INCREASED

\begin{tabular}{|l|c|c|c|c|c|c|c|}
\hline RESPONSE & PRINCIPAL & TEACHER & $\begin{array}{c}\text { SERVICE } \\
\text { PERSONNEL }\end{array}$ & PARENT & $\begin{array}{c}\text { AT-LARGE } \\
\text { MEMBER }\end{array}$ & $\begin{array}{c}\text { AT-LARGE } \\
\text { MEMBER, } \\
\text { BUSINESS }\end{array}$ & STUDENT \\
\hline Significantly & 4 & 7 & 2 & 3 & 2 & 1 & 1 \\
\hline Very Much & 11 & 25 & 20 & 10 & 3 & 3 & 3 \\
\hline Moderately & 13 & 35 & 12 & 16 & 3 & 3 & 0 \\
\hline Somewhat & 14 & 25 & 11 & 11 & 1 & 0 & 1 \\
\hline Not At All & 2 & 7 & 3 & 2 & 0 & 0 & 0 \\
\hline Don't Know & 0 & 2 & 3 & 2 & 3 & 3 & 0 \\
\hline MEAN & 2.977 & 3.000 & 2.854 & 2.976 & 2.222 & 2.285 & 2.200 \\
\hline S.D. & 1.138 & 1.060 & 1.000 & .953 & .737 & 2.838 & 1.200 \\
\hline
\end{tabular}


TABLE NUMBER 94

QUESTION NUMBER 25 RESPONSES BY LONGEVITY

INVOLVEMENT OF TEACHERS INCREASED

\begin{tabular}{|l|c|c|c|c|c|}
\hline RESPONSE & 1 YR. & 2 YRS. & 3 YRS. & 4 YRS. & 5+ YRS. \\
\hline Significantly & 2 & 3 & 1 & 1 & 11 \\
\hline Very Much & 17 & 18 & 9 & 11 & 16 \\
\hline Moderately & 18 & 22 & 21 & 7 & 12 \\
\hline Somewhat & 17 & 19 & 6 & 7 & 14 \\
\hline Not At All & 3 & 3 & 2 & 2 & 4 \\
\hline Don't Know & 8 & 3 & 1 & 1 & 0 \\
\hline MEAN & 3.035 & 3.015 & 2.974 & 2.928 & 2.719 \\
\hline S.D. & .843 & .910 & .692 & 1.066 & 1.527 \\
\hline
\end{tabular}


TABLE NUMBER 95

QUESTION NUMBER 25 RESPONSES BY DISTRICT SIZE

INVOLVEMENT OF TEACHERS INCREASED

\begin{tabular}{|l|c|c|c|}
\hline \multicolumn{1}{|c|}{ RESPONSE } & SMALL & MEDIUM & LARGE \\
\hline Significantly & 10 & 2 & 7 \\
\hline Very Much & 22 & 22 & 31 \\
\hline Moderately & 26 & 34 & 22 \\
\hline Somewhat & 17 & 32 & 14 \\
\hline Not At All & 4 & 6 & 4 \\
\hline Don't Know & 7 & 4 & 2 \\
\hline MEAN & 2.784 & 3.187 & 2.705 \\
\hline S.D. & 1.075 & .835 & 1.041 \\
\hline
\end{tabular}

QUESTION \# 26: Add any comments which you feel are relevant to this survey or to School Improvement Councils in general. Only a few respondents answered this question and the researcher has listed them in the following table. 


\section{TABLE NUMBER 96}

\section{GENERAL COMMENTS}

\section{SUMMARY OF GENERAL COMMENTS}

Our school has been "on hold" for five years as we are in the process of building a new school through SBA funding. But due to opposition to consolidation and the election of two board members in May that are very much against the new school, we are at a standstill. It is time for the LSIC to make some demands of the system, instead of waiting for a new school.

The school improvement council is a positive force potential only impaired by poor local SIC vision.

Appears to be a waste of time.

Another burden on the school administrator.

Effective avenue for communication.

School Improvement Councils are involved with improving the school.

Teachers should be monitored while they are teaching.

Our main problem currently has been the lack of support and respect from our local board of education.

I think that maybe this survey won't apply too much to our situation here. Most parental involvement comes through the PTO - ditto for business partnerships with the school. The SIC has all the representation that you list and we discuss freely any suggestions that arise and are advantageous for the improvement of the school. Our leader is elected by the council members. Mostly it is the principal because he/she has more knowledge of events and is available to lead in the pursuit/attainments being sought as well as knowledge/training in methods needed to achieve them.

Our LSIC has lack of motivation and involvement.

Our LSIC members need to volunteer their time. 


\section{SUMMARY OF GENERAL COMMENTS}

School Improvement Councils are a step in the right direction in that more direct local control of schools will strengthen them as opposed to such supposedly penny-wise but pound foolish ideas such as regionalization of county boards of education.

We probably don't need an LSIC or Faculty Senate.

School improvement councils are good "sounding blocks" for new programs, ideas, or changes that are being considered for a school.

The meetings are too few and too far between to follow through on some projects. It is easy for items to become dormant.

I believe it is very difficult to involve business people in the process. Many of them do not feel comfortable outside of their area of expertise. 


\title{
CHAPTER V
}

\section{Summary and Recommendations}

\author{
Introduction
}

The purpose of this study was to re-examine the perceptions of school improvement councils in the State of West Virginia. Though the main thrust of this study is concerned with the perceived role and function of council members, data were also gathered concerning their perceived successes and failures at the individual schools surveyed. Similar data were collected in an earlier study with the results suggesting a replication study be completed using council members of the 1998-99 school year (Dean 94). This study is a replication of Dr. Dean's study. Data from this study were compared to the earlier data and changes were noted.

This study was designed to use a sample consisting of 100 schools chosen in a random manner and stratified to include small, medium, and large schools based on student population. Data collection was accomplished by the school principal distributing the surveys to the individual school improvement council members and these members returned their responses to the researcher by direct mail service. This allowed complete confidentiality for the respondent. 


\section{Justification of the Study}

The earlier study suggested school improvement council members were mostly untrained, did not understand their roles as council members, and basically focused their attention on facility repairs. Many doubtful points remain unanswered. Has training been increased for council members? Is student achievement being improved due to improvement council activities? Are the parents and community members becoming more involved in the local decisionmaking process? Are principals still controlling the actions of the school improvement council? How much school reform has actually been achieved through the creation of school improvement councils? Answers to these and other questions can provide insight to the Legislature when determining if other legislation is needed to make school improvement councils more effective.

\section{Problem Statement}

The problem researched in this study was: To what extent has reform legislation constituted from the top down impacted local decision-making processes, particularly concerning those assigned to the school improvement councils in West Virginia, especially since 1994? Subproblems included: (1) To what extent did council members perceive their actions to be effective? (2) What 
activities had the school improvement endeavored? (3) Did schools utilize their improvement councils differently? (4) Were school improvement council members' perceptions influenced by the demographic characteristics of their location? (5) Did the council members' roles influence his/her perceptions? (6) What changes, if any, has occurred concerning identified perceptions of council members since Dr. Dean's study in 1994?

\section{Research Procedures}

A sampling was used to obtain the necessary data. Selection of this sampling was achieved using a random process from a stratified list based on student population. This allowed equal representation based on school population. Of the 783 schools in West Virginia, the researcher chose a sample of 100 schools. Stratification by student population revealed 186 of these schools were considered small (less than 200 students), 411 schools were considered medium (between 200 to 500 students), and 186 schools were considered large (over 500 students). From these respective groupings, a random number process was employed to select 33 small schools, 34 medium schools, and 33 large schools. The principals of the selected schools were furnished copies of the survey instrument to be distributed to each school improvement council member. A stamped self- 
addressed envelope was also provided each respondent for the direct return of the survey to the researcher by the United States Postal Service.

Data were collected from 71 of the 100 schools surveyed. Of those 71

schools, 23 were from the small sized grouping, 23 were from the medium sized grouping, and 25 were from the large sized grouping. The data were tabulated using the Abstat computerized statistical program. Cross tabulations were employed between the demographic data requested and the 25 questions reflecting the perceptions of improvement council members. Descriptive statistics were determined using mean, standard deviation, and chi square. These results were made known in Chapter IV.

\section{Research Questions}

\section{To what extent have local school improvement councils been involved in the decision-making process at their schools?}

When asked the extent the local school improvement council had enacted programs to encourage parental involvement in their schools, $15.4 \%$ replied always and $49.1 \%$ stated this was done regularly. The majority felt parental involvement programs were always or regularly encouraged by their local school

improvement councils. When asked if businesses allowed time for parents to visit 
with teachers, $31.5 \%$ indicated occasionally and $24.5 \%$ replied rarely. These percentages reflect the perception that businesses allow their employees time to meet with teachers occasionally to rarely. When asked if advice was sought from the business community, respondents replied this was done occasionally by $42.9 \%$ and regularly by $32.6 \%$. Businesses contributing advice to the council was perceived as $41.4 \%$ did so on a regular basis and $23.5 \%$ did so occasionally. Perceptions also indicated $15.4 \%$ of the time businesses always contributed suggestions to the council. The majority of the respondents $(56.9 \%)$ felt that businesses always or regularly contributed advice.

In an effort to determine if school reform had actually been perceived by the respondents, questions 21-25 asked about the increased involvement of all parties in the decision-making process of the school's operation. Parental involvement was determined to be increased very much (31.6\%) and moderately $(29.3 \%)$. This total $(60.9 \%)$ reflects a perceived increase in parental involvement. Teachers were also perceived to have more involvement in the decision-making process with $30.7 \%$ perceived as moderately and $28.1 \%$ as very much for a total of $58.8 \%$ of the respondents perceiving teachers as being more involved in the decision-making process. This is a strong statistic when considering the majority of the respondents were teachers. The involvement of business leaders in the 
decision-making process was perceived as somewhat (29.1\%) and moderately (24.9\%). A large portion of respondents (23\%) felt business leaders had increased decision-making involvement very much. Service personnel involvement was perceived nearly the same as business with $30.7 \%$ reporting somewhat and $30.3 \%$ reporting moderately. The statistics for student involvement ranged $28.6 \%$ as somewhat to $28.2 \%$ as moderately.

\section{What activities have School Improvement Councils undertaken since their creation?}

Respondents perceived their most common activity to be encouraging school volunteer programs. Always was selected $35.9 \%$ and regularly was selected $36.3 \%$ for a total of $72.2 \%$ agreement. The second most perceived activity was the encouragement of the use of school facilities by the community. Always was chosen $20.9 \%$ of the time and regularly was chosen $38.1 \%$ for a total of $59 \%$.

Respondents as a whole did not perceive waivers as an activity of local school improvement councils. When asked about requesting waivers for State Board Policies, 59.2\% stated they either never applied or didn't know. 64.7\% indicated they didn't know if any State Board waivers were obtained. The same results applied to waivers requested of local board policies. Never or didn't know 
was chosen by $58.7 \%$ of the respondents when asked if local waivers were requested and $64.1 \%$ selected never or didn't know if local waivers were obtained. It appears these large percentages reflect most local school improvement council members are unfamiliar with waivers and the procedures used in obtaining them.

The activity of developing a mentorship program was performed by $23.9 \%$

of the council members surveyed. Also $35.4 \%$ of the members indicated they had applied for or received the "School of Excellence" award.

\section{Do the members of the school improvement council perceive their}

\section{activities as contributing to the improvement of their schools?}

Question \# 15 requested respondents to list the five major

accomplishments of their school improvement council. Improving safety conditions and facilities was the number one accomplishment listed by a large majority. Student oriented programs and policy development was the second most listed accomplishment. The third major accomplishment listed was the improvement of communication, involvement, and coordination with parents, businesses, and community members. Curriculum changes or improvements was listed fourth. Technology upgrades, local school improvement council organizational improvements, and securing additional staff were also listed. 
Question \# 18 asked if the activities of the school improvement council improved the quality of teacher performance in their school. Moderately was chosen $32.6 \%$ of the time and somewhat was chosen by $24.5 \%$. Significantly and very much totaled $16.5 \%$ and not at all and didn't know totaled $26.4 \%$. Question \# 19 asked the same question of service personnel performance. Moderately was chosen $28.9 \%$ of the time and somewhat was chosen $23.2 \%$. Significantly and very much totaled $9.5 \%$ and not at all and don't know totaled $38.4 \%$. Service personnel performance was slightly lower than teacher improvement. Question \# 20 asked if there was improved performance of the students. Moderately was chosen by $27.1 \%$ of the respondents and somewhat was chosen $25.9 \%$.

Significantly and very much totaled $24.4 \%$ and not at all and never totaled $22.5 \%$. It appears school improvement council members perceive their activities as moderately to somewhat improving the performance of teachers, service personnel, and students. They have also listed student oriented programs and policies as their second major accomplishment. This reflects a beginning shift of emphasis towards improvements other than those of the physical plant.

\section{What examples of contributions do members of improvement councils list} most frequently? 
Question \# 16 asked the respondents to list the two major strengths of their council. The most common response chosen was harmony among members. Increasing involvement in volunteer programs was listed second. Organizational improvements were listed third. Programs concerning student improvement was listed fourth with communication, business partnerships, and strong leadership also listed.

\section{What problems do members of school improvement councils perceive that} may keep them from being effective?

Question \# 17 on the survey asked respondents to list the two major weaknesses of their school improvement council. Many respondents chose to leave this question blank, either not wanting to admit they had weaknesses or believing they had none. Of those responding, the most common weakness was lack of members exhibiting interest in participation. The second greatest perceived weakness was lack of leadership. Not enough business support was listed third and fourth was convenient meeting times and durations. Lack of training was listed fifth and lack of funding was listed sixth. Non-academic concerns, lack of recognition by local boards of education, and lack of communication were also listed. 


\section{Are there similarities and differences among and between school improvement councils that can be attributed to school size? district size? longevity of membership? attendance of SIC meetings? training? representative role of the member?}

The chi square tables listed in Chapter IV show there are differences when research questions are cross tabulated with the different demographic categories. The demographic category deviating the most often when compared to the total population was role of respondent as reported in 13 of the 22 questions. All of the respondents exhibited deviation when asked about State and local waivers requested or obtained. Parents were less convinced that the business member actively contributed suggestions for school improvement. At-large members were less likely to agree that businesses were encouraged to allow parents time to visit with teachers. Mentorship programs were perceived as less likely to occur by principals and parents. Principals and teachers perceived application for "School of Excellence" awards would less likely occur.

The section of perceived school reform through increased involvement of local people also exhibited deviations. Parents and at-large members felt there was little likelihood business leaders and students had increased involvement in the decision-making process. Parents also felt service personnel had not exhibited 
increased involvement in the decision-making process. Teachers felt they were less likely to have increased involvement in the school's decision-making process. Training also showed significant deviation with 11 out of 22 questions using chi square analysis and the .05 test. Those not trained believed questions 5, $7,8,18,20,21,22,23$, and 24 would be less likely to occur regularly. These numbers may be somewhat suspect in that such a large majority $(78.2 \%)$ of the respondents had not had training.

The next demographic variable showing significant deviation using the chi square statistic was longevity of service. Of the 22 questions on the survey, 10 displayed deviation. Third year members did not believe programs to encourage parental involvement would occur on a regular basis. First, second, third, and fourth year members felt it unlikely that volunteer programs would occur regularly All members felt there were no actions regarding waivers of State Board Policies and second, third, and fourth year members felt it less likely to request or obtain local board waivers. Mentorship programs were perceived as less likely to occur regularly by third and fourth year members. First, second, and fourth year members perceived similar results with questions 25,22 , and 20 respectively. Chi square analysis using the .05 test revealed medium sized school's personnel perceived that it unlikely that parental involvement programs, 
community use of school facilities, waivers of State Board Policies, and teacher involvement in decision-making would occur regularly. Attendance grouping revealed members had little faith business leaders would be involved in the decision-making process. Respondents who perceived their school to be medium on the scale perceived waivers, parental involvement, and teacher involvement in the decision-making process would less likely occur. These deviations may be somewhat suspect since the medium grouping was $25 \%$ larger than each of the small and large groups.

\section{Data Comparison Since 1994}

The major thrust of this study was to determine the similarities and differences in regards to the questions concerning West Virginia school improvement councils. The base line will be the study performed by Dr. Martha Dean in 1994. Her data were compared to the data in this study. These comparisons provided insight to those concerned with improved effectiveness of local school improvement councils. Comparison of the data should reflect the improvement or decline in school improvement council activities with regards to school reform. 
Question \# 1 was concerned with the involvement of local people in school activities. Dr. Dean's study revealed "more than one-half" of the parents were either always or regularly involved with school activities. The 1999 study reveals this trend continuing with $64.5 \%$ of the respondents perceiving parents to be involved in the schools always or regularly. Business was perceived as involved rarely to occasionally in Dr. Dean's study. In this study, a slight improvement is shown in the same response category. When compared to seeking advice from the business community, both studies still reflect the same percentages of occasionally to regularly. Contribution of ideas to the school improvement council by business members is still strong since both studies revealed this perception to be always to regularly.

Comparisons of questions 21-25 were designed to show the amount of involvement in decision-making by various groups. Parents were listed as moderately to somewhat involved in Dr. Dean's study but this study reveals an increase in involvement with moderately to very much. Teachers were perceived with the same level of involvement in both studies, that being very much to moderately. Business leaders, service personnel, and students were perceived to be involved in the decision-making process moderately to somewhat in both studies. 
Question \# 2 was concerned with what activities have school improvement councils undertaken since their creation. The two most frequently reported activities in both studies were the encouragement of school volunteer programs and the use of school facilities by the community. Both studies agreed waivers of State Board Policies and local board policies were seldom requested or obtained. This study also revealed a $7.5 \%$ increase in the creation of mentorship programs and an increase of 19\% in the applications for "School of Excellence" awards. The conclusion to question \# 2 is that the majority of activities continued to be geared towards volunteer programs and use of school facilities by the community but are beginning to shift towards other activities.

Question \# 3 asked if school improvement council activities are being perceived by the members as improving their schools. This information was obtained by asking council members to list their council's five major accomplishments. By a large margin in both studies, facility improvements was the most listed accomplishment. Dr. Dean's study reflected communication, coordination, and involvement of business, parents, and community members as the second most perceived accomplishment. This study shows student programs and policy development to be the second most perceived accomplishment. Curriculum improvement, administrative changes and school/community 
activities respectively were ranked the same order in both studies. It appears more activities are beginning to be more student oriented since 1994.

Question \# 4 asked the council members to list what they perceived as the council's two major strengths. The most frequently cited strength in both studies was membership quality. The second most expressed strength in both studies was the increase in volunteer programs. There was a difference in the third most cited strength. Dr. Dean's study revealed this to be community relations while this study proposed student improvement programs followed by community relations. This is another example of students becoming more of a focus point for school improvement councils.

Question \# 5 asked council members what they perceived to be the council's two major weaknesses. In Dr. Dean's study, as well as this study, there were very few responses. Using the responses given, both studies agreed the greatest perceived weakness to be lack of participation by council members. Dr. Dean's study listed lack of meeting time, lack of training, and lack of funding to be the next successive weaknesses. This study listed these perceptions in the same order as well, but after lack of leadership and lack of business support.

Question \# 6 asked if there were demographic influences on school improvement councils such as school size, district size, longevity of membership, 
attendance of council meetings, training, and the roles of the respondents. The chi square statistic revealed some deviations in all the subgroups. Role of respondent exhibited the greatest frequency of deviations in both studies, occurring 12 times in Dr. Dean's study and 13 times in this study. In the base line study, the second most occurring deviation was school size but in this study it was training. Both studies agreed longevity had the third most deviations using the .05 test. In this study, size of school and district size were ranked next with attendance being the least demographic influence. This differs from the earlier study which ranked attendance and district size as fourth and fifth with training being the least demographic influence. Comparisons can be made using the response summary tables listed in Appendix C.

\section{Recommendations for Action}

Although length of service on the school improvement council was a problem in an earlier study (Dean 94), this is no longer a problem. First, second, and fifth year members equally comprise three-fourths of the total membership. Third and fourth year members together equal the remaining fourth. This represents an evenly dispersed membership. 
Training

The training of school improvement council members still remains a problem. After being in existence for nine years, $78.2 \%$ of the members surveyed revealed they had not received any training. Lack of training could explain why lack of leadership was listed as the third greatest weakness. Without training, the SIC's are left to "learn as you go" and much progress will be impeded through unnecessary error.

The solution could be a system installed similar to the one used for the board of education members in West Virginia. Participation could be mandatory and offered by the RESA affiliation of each county. A centralized location could be used for the training. The State Department of Education could create an office dedicated to the training of school improvement council members. This would allow them the opportunity to learn proper procedures and leadership skills. Proper training will allow SIC members to broaden their activities at a much quicker pace.

\section{$\underline{\text { Legislative Review }}$}

Many respondents indicated a perception of a duplicity of services at their schools. Faculty Senates, LSIC's, PTO's, and community volunteers were all working toward the same goals. Many LSIC members also belong to several of 
the other groups and found it difficult to have enough meeting time. Several respondents indicated the lack of need for a school improvement council since another body was already the dominant program at their school. Perhaps the Legislature should review these bodies with the intent of assigning new duties to certain groups where duplication occurs. With the assignment of new duties and powers, interest would increase by LSIC members. Increasing interest would alleviate the greatest perceived weakness indicated in this study.

\section{$\underline{\text { State Department Review }}$}

Support from business was listed by the respondents as the third greatest weakness. Because West Virginia is a rural state, many schools find it difficult to obtain business support. Progress has been made with groups like Partners in Education but more needs to be done. Perhaps the State Department of Education could devise a method of connecting the rural schools to the businesses located in a more populated area. This could provide the financial support and business advice so badly needed by the rural schools.

\section{Research Suggestions}

Lack of training of school improvement council members in West Virginia is still a major issue. It would be interesting to compare West Virginia to other 
states to see if they offer training to school improvement council members and, if so, has this training aided in making school improvement councils more effective. In a effort to improve business involvement in the schools, a study to discover what expectations business has for the school system could be very helpful. This information could assist the local schools in improving their relationships with businesses. Better relations increase the likelihood of informational and financial support from business.

A study of the West Virginia Legislature to determine if school improvement councils have lived up to their expectations could be helpful. Suggestions for improvement and a new awareness by Legislators could prompt needed legislation for growth. This would allow school improvement councils an opportunity to obtain their greatest potential and perhaps remove some of the duplication of activities found by this study.

Longevity of service on the school improvement council is spread evenly except for the third and fourth year members. It would be interesting to know why so many people left the councils three to four years ago. Information from this study could be helpful in avoiding repeated actions that may cause a large majority of members to leave the council in the future. 
Funding of the school improvement council was another area of concern listed by members. A study of school improvement council members on their use of potential funding for items other than facility improvements may provide the catalyst needed to continue the momentum of having SIC's involved in activities more student oriented. Perhaps this funding formula could be similar to Faculty Senates.

\section{Researcher's Reflections}

After absorbing the data collected in this study, the researcher wishes to take the liberty to reflect on the perceptions of school improvement council members. Key components listed by the respondents were parental involvement, business involvement, and training.

Parents are becoming more involved in the operation of the school improvement council. From this increased involvement they are now perceived as having more influence on the decision-making process of their schools. Parental involvement has created a greater use of school facilities by the community. Being in these school facilities, community members realize a sense of need and have increased participation in school volunteer programs. The majority of their efforts 
are still concerned with facility improvements but there is some movement toward other student oriented activities.

Businesses have long been a source of informational and financial support. When they have been asked for support, many have responded. This area needs exploration for ways to increase this participation. Businesses are the likely recipients of our graduating students. It is obvious they would want input into the educational system.

Training of school improvement council members still remains a high priority. Most members are unsure of their roles and responsibilities so therefore revert to focusing their attention to physical plant improvements. Because these members lack the confidence that would come from proper training, principals and teachers still provide the majority of leadership and ideas for the council. If others are to become more involved in the decision-making process, this needs to change. Otherwise, principals and teachers will try to preserve the status quo when dealing with the operation of the schools. Maintaining the status quo inhibits school reform.

It appears school improvement councils were created nine years ago by the West Virginia Legislature and then forgotten. Lack of substantial powers, awareness programs, funding measures and adequate training leave questions 
about the effectiveness potential and growth. Lacking the necessary support, the local school improvement councils in West Virginia have not become the leaders of school change. Perhaps the creation of school improvement councils in West Virginia was purely a political move to give the public the impression the Legislature desired to transfer the control of public education through site-based management.

The lack of proper training and the establishment of realistic guidelines have allowed school improvement councils to grow in many directions. Some have attempted to become political bodies that actually must approve any/all actions taken at their school. If their input is ignored, they simply band together to elect new board of education members who will continue to recognize their power.

School improvement councils are just beginning to shift towards more student oriented programs. Parents are becoming more involved in the school system as volunteers but have yet to become a significant part of the decisionmaking process. Top down mandated school reform seems to be a very slow process that can easily be controlled by the upper levels of the governing body. With so much control, the effectiveness of this type of school reform remains questionable. 


\section{Reference List}

Aguilar, V. 1995. "Restructuring a Texas High School: A Profile of Virginia Aguilar." Journal of Staff Development 16: 65-67.

Alfonso, R., G. Firth, and R. Neville. 1975. Instructional Supervision: A Behavior System. Boston, MA: Allyn and Bacon.

Allington, Richard L. and Patricia M. Cunningham. 1996. Schools That Work: Where All Children Learn to Read and Write: Harper Collins Publishing.

Alutto, J. A., and J. A. Belasco. 1972. "Patterns of Teacher Participation in School Decision-Making.” Educational Administration Quarterly 8 (January): 2741.

Ames, R. and C. Ames. 1994. Creating a Mastery-Oriented Schoolwide Culture: A Team Leadership Perspective. Berkeley, CA.: McCutchan.

Anderson, E. and T. Keith. 1997. “A Longitudinal Test of a Model of Academic Success for At-Risk High School Students.” Journal of Educational Research 90 (May/June): 259-269.

Asayesh, G. 1994. "The Changing Role of Central Office and Its Implications for Staff Development." Journal of Staff Development 15: 2-5. 
Baines, L. 1997. "Future Schlock: Using Fabricated Data and Politically Correct Platitudes in the Name of Educational Reform." Phi Delta Kappan (March): 493-498.

Barber, B. 1992. An Aristocracy for Everyone: The Politics of Education and the Future of America. New York, NY.: Ballantine Books.

Barnard, C. 1938. Functions of the Executive. Cambridge, MA.: Harvard University Press.

Beckhard, R. and R. Harris. 1987. Organizational Transitions, $2^{\text {nd }}$ ed. Reading, PA.: Addison-Wesley.

Bennis, W., K. Benne, and R. Chinn. 1969. The Planning of Change. New York, NY.: Holt, Rinehart, and Winston.

Berman, P. and T. Gjelten. 1982. Improving School Improvement: A Policy Evaluation of the California School Improvement Program (Seminar II). Berkeley, CA.: Berman, Weller Associates.

Bickel, R. and L. Lange. 1995. “Opportunities, Costs, and High School Completion in West Virginia: A Replication of Florida Research.” Journal of Educational Research 88 (Jul/Aug): 363-371.

Boleman, L. and T. Deal. 1991. Reframing Organizations. San Francisco, CA.: Jossey-Bass Publishers. 
Bowles, D. 1980. School-Community Relations, Community Support, and Student Achievement: A Summary of Findings. Madison, WI.: R and D Center for Individualized Schooling.

Bracey, G. 1995. "The Fifth Bracey Report on the Conditions of Public Education.” Phi Delta Kappan 77 (Oct): 149-160.

Brubaker, Dale L. and Larry D. Coble. 1997. Staying On Track. Thousand Oaks, CA.: Corwin Press.

Bryk, A., J. Easton, D. Kerbow, S. Rollow, and P. Sebring. "The State of Chicago School Reform." Phi Delta Kappan 76 (January): 74-78.

Carnegie Foundation for the Advancement of Teaching. 1988. Teacher Involvement in Decision-Making: A State by State Profile. New York, NY.: Carnegie Corporation.

Clune, W. H. and P. White. 1988. School-Based Management Institutional Variation, Implementation, and Issues for Further Research. New Brunswick, NJ.: Center for Policy Research in Education, Rutgers University.

Conley, D. 1993. Roadmap To Restructuring: Policies, Practices, and the Emerging Visions of Schooling. Eugene, OR.: ERIC Clearinghouse on Educational Management. 
Conley, S. C. and S. B. Bacharach. 1990. "From School-Site Management to Participatory School-Site Management." Phi Delta Kappan 71 (July): 539544.

Conway, J. 1984. "The Myth, Mystery, and Mastery of Participative DecisionMaking in Education." Educational Administrative Quarterly 20 (March): $11-40$.

Cook, William J. 1990. Strategic Planning. Montgomery, AL.: Cambridge Management Group.

Crockenberg, V. and W. W. Clark. 1979. "Teacher Participation in School Decision-Making: The San Jose Teacher Involvement Project.” Phi Delta Kappan 60 (February): 115-118.

Dachler, H. and B. Wilbert. 1978. "Conceptual Dimensions and Boundaries of Participation in Organizations: A Critical Evaluation.” Administrative Science Quarterly 25: 1-39.

Darling-Hammond, L. 1993. "Reframing the School Reform Agenda." Phi Delta Kappan 74 (October): 753-761.

David, J. 1994. “School-Based Decision-Making: Kentucky's Test of Decentralization.” Phi Delta Kappan 75 (September): 706-712. 
David, J. 1989. "Synthesis of Research on School-Based Management."

Educational Leadership 48 (August): 11-15.

David, J. 1991. "What It Takes to Restructure Education.” Educational Leadership 48 (August): 45-53.

David, Jane L. 1996. "The Who, What, and Why of Site-Based Management." Educational Leadership (January): 7-8.

David, J. and S. Peterson. 1984. "Can Schools Improve Themselves? A Study of School-Based Improvement Programs." Palo Alto, CA.: Bay Area Research Group.

David, J., S. Purkey, and P. White. 1988. "Restructuring In Progress: Lessons From Pioneering Districts." Paper Presented at the National Governor's Association. Washington, D.C.

Dean, Martha H. 1994. "School Improvement Councils in West Virginia." Ed D. Dissertation., West Virginia University.

DeYoung, A. and B. Lawrence. 1995. "On Hoosiers, Yankees, and Mountaineers.” Phi Delta Kappan 77 (Oct): 104-112.

Draft, R. 1983. Organization Theory and Design. St. Paul, MN.: West Publishing Company.

Drucker, P. 1992. Managing The Future. New York, NY.: Dutton. 
Elmore, R. 1988. Models of Restructured Schools. East Lansing, MI.: Center for Policy Research in Education, Michigan State University.

Elmore, R. and M. McLaughlin. 1988. Steady Work: Policy, Practice, and the Reform of American Education. Santa Monica, CA.: RAND Corporation.

Evans, R. 1993. “The Human Face of Reform.” Educational Leadership 51 (January): 19-23.

Fantini, M. 1980. "Community Participation: Alternative Patterns and Their Consequences on Educational Achievement." Paper Presented at American Educational Research Association Annual Meeting.

Finn, Chester. 1991. We Must Take Charge. New York, NY.: The Free Press.

Follet, M. 1987. The Essentials of Leadership. The Great Writings in Management and Organizational Behavior. New York, NY.: Random House.

Fullan, M. 1993. Change Forces. London, England: The Falmer Press.

Gomez, J. 1989. “The Path to School-Based Management Isn't Smooth, But We're Scaling the Obstacles One by One." American School Board Journal 176: 20-22.

Goodlad, J. 1984. A Place Called School. New York, NY.: McGraw Hill. 
Goodlad, J., M. Klein, and Associates. 1970. Behind the Classroom Doors. Worthington, OH.: Charles A. Jones.

Greenbert, S. 1975. "The Consequences of Worker Participation: A Clarification of the Theoretical Literature." Social Sciences Quarterly 56: 191-201.

Hall, G. and S. Hord. 1987. Change in Schools: Facilitating the Process. Albany, NY.: State University of New York Press.

Hargreaves, A. 1995. "Renewal in the Age of Paradox." Educational Leadership 52 (April): 15-18.

Harrington-Lueker, D. 1996. "School Boards At Bay." The American School Board Journal 5: 18-22.

Henderson, James G. and Richard D. Hawthorne. 1995. Transformative Curriculum Leadership. Englewood Cliffs, NJ.: Prentice-Hall.

Hoy, W. and C. Miskel. 1996. Educational Administration: Theory, Research, and Practice. New York, NY.: McGraw-Hill.

Huberman, M. and M. Miles. 1984. Innovation Up Close: How School Improvement Works. New York, NY.: Plenum Press.

Hunt, A. 1997. "What's Wrong and Right with Our Schools?" The Wall Street Journal (March). 
Johnson, Susan M. 1996. Leading to Change: The Challenge of the New Superintendency. San Francisco, CA.: Jossey-Bass Publishers.

Kelly, S. 1986. “A New Approach to School Decision-Making.” Virginia Journal of Education 80 (April): 17-18.

Klein, S., E. Medrich, V. Perez-Ferreiro. 1996. Fitting the Pieces: Educational Reform that Works. US Department of Education: MPR Associates.

Langdon, C. 1996. “The Third Phi Delta Kappa Poll of Teachers' Attitudes Towards the Public Schools.” Phi Delta Kappan (November): 244-250.

Levin, H. 1988. Accelerated Schools for At-Risk Students. New Brunswick, NY.: Center for Policy Research in Education. Rutgers University.

Levin, H. 1976. Educational Reform: Its Meaning and the Limits of Educational Reform. New York, NY.: McKay.

Levine, D. 1991. “Creating Effective Schools: Findings and Implications from Research and Practice." Phi Delta Kappan 72 (May): 389-393.

Local Schools Involvement Act of 1990. School Laws of West Virginia 18. 1993. Malen, B., R. Ogawa, and J. Kranz. 1990. “Unfilled Promises.” The School Administrator 42 (February): 30, 32, 53-56, 59. 
Marburger, C. 1985. One School at a Time: School Based Management: A

Process for Change. Columbia, MD.: National Committee for Citizens in Education.

Marris, P. 1986. Loss and Change. London, England: Routledge and Kegan Paul.

Mehlinger, H. 1995. School Reform in the Information Age. Bloomington, IN.: Indiana University Printing Services.

Meier, D. 1987. "Success in East Harlem: How One Group of Educators Built a School that Works." American Educator 11 (March): 36-39.

Mortimore, P., P. Sammons, L. Stoll, D. Lewis, and R. Ecob. 1988. School Matters: The Junior Years. Somerset, United Kingdom: Open Books.

Newman, F., M. King, and M. Rigdon. 1997. “Accountability and School Performance: Implications From Restructuring Schools.” Harvard Educational Review 67 (Spring): 41-63.

Noblix, G. and V. Dempsey. 1996. The Social Construction of Virtue. New York, NY.: State University of New York Press.

Oakes, J. and M. Lipton. 1990. Making the Best of Schools. Bingham, NY.: VailBallou Press.

Ogawa, R. 1992. "Institutional Theory and Examining Leadership in School." International Journal of Educational Management 6 (March): 14-21. 
Owens, R. 1987. Organizational Behavior in Education. Englewood Cliffs, NJ.: Prentice-Hall.

Parker, B. 1979. “School-Based Management: Improve Education by Giving Parents and Principals More Control of Your Schools.” American School Board Journal 7: 20-24.

Payzant, T. 1989. “To Restructure Schools, We've Changed the Way Bureaucracy Works." The American School Board Journal 176 (October): 19-22.

Peters, T. and N. Austin. 1985. A Passion for Excellence: The Leadership Difference. New York, NY.: Random House.

Pierce, L. 1980. “School-Based Management.” OSSC Bulletin 10: 1-49.

Plucker, J. 1998. "The Relationship Between School Climate, Conditions, and Student Aspirations." Journal of Educational Research 91 (Mar/Apr): 240-247.

Policies to Promote School Board Effectiveness. 1993. School Laws of West Virginia 18.

Postman, N. 1995. The End of Education. New York, NY.: Alfred A. Knopf.

Rebarber, T. 1992. "State Policies for School Restructuring." National Conference of State Legislatures and the Vanderbuilt University Educational Excellence Network. 
Richman, S. 1994. Separating School and State. Fairfax, VA.: The Future of Freedom Foundation.

Rosenholtz, S. 1987. "Educational Reform Strategies: Will They Increase Teacher Commitment?" American Journal of Education 95 (April): 534-562.

Sarason, S. 1990. The Predictable Failure of Educational Reform. San Francisco, CA.: Jossey-Bass.

Schein, E. 1985. Organizational Culture and Leadership. San Francisco, CA.: Jossey-Bass.

Schmuck, R. and P. Runkel. 1994. The Handbook of Organizational Development in Schools and Colleges. Prospect Heights, IL.: Waveland Press.

Schneider, G. 1984. "Teacher Involvement in Decision-Making: Zones of Acceptance, Decision Conditions, and Job Satisfaction." Journal of Research and Development in Education 18 (January): 25-32.

Sergiovanni, T. 1990. Value-Added Leadership: How to Get Extraordinary Performance in Schools. New York, NY.: Harcourt Brace Jovanovich.

Singh, K. and B. Billingsley. 1998. "Professional Support and Its Effects on Teacher's Commitment.” Journal of Educational Research 91 (Mar/Apr): 229-240. 
Taylor, B. and D. Levine. 1991. "Effective Schools Projects and School-Based Management." Phi Delta Kappan 72 (May): 394-397.

Timar, T. 1989. “The Politics of School Restructuring.” Phi Delta Kappan 71 (April): 264-275.

Timperley, H. 1998. "Performance Appraisal: Principals' Perspectives and Some Implications." Journal of Educational Administration 36 : 44-58.

Walberg, H., M. Bakalis, J. Bast, and S. Baer. 1989. "Restructuring the Nation's Worst Schools." Phi Delta Kappan 70 (October): 802-805.

Walberg, H. and R. Niemiec. 1994 "Is Chicago School Reform Working?" Phi Delta Kappan 75 (September): 713-715.

Weischadle, D. 1980. "School Based Management and the Principal." The Clearinghouse 54 (February): 53-55.

White, P. 1988. Research Materials on School-Based Management. New Brunswick, NJ.: Center for Policy Research in Education, Rutgers University.

White, B. and T. Corcoran. 1988. Successful Secondary Schools: Visions of Excellence in American Education. Philadelphia, PA.: Farmer Press. White, P. 1989. “An Overview of School-Based Management: What Does the Research Say?" NASSP Bulletin 73 (518): 1-10. 
Wiesner, D. 1987. The Shape of School-Based Management. Unpublished Handout for Department of Curriculum and Programs. St. Louis Public Schools. St. Louis, MO.

Wiles, J. 1993. Promoting Change In Schools. New York, NY.: Scholastic.

Wiles, K. 1955. Supervision for Better Schools. Englewood Cliffs, NJ.: PrenticeHall.

William, R., B. Harold, J. Robertson, and G. Southworth. 1997. "Sweeping Decentralization of Educational Decision-Making Authority.” Phi Delta Kappan 78 (April): 627-629.

Wirt, F. and M. Kirt. 1992. Schools in Conflict. Berkeley, CA.: McCutchan Publishing.

Wissler, D. and F. Ortiz. 1988. The Superintendent's Leadership in School Reform. Philadelphia, PA.: The Palmer Press.

Wohlstetter, P and A. Odden. 1992. "Rethinking School-Based Management Policy and Research.” Educational Administration Quarterly 18 (April): $529-549$.

Zigarelli, M. 1996. “An Empirical Test of Conclusions From Effective Schools Research.” Journal of Educational Research 90 (Dec): 103-111. 
APPENDIX A

\section{SURVEY INSTRUMENT}


Dear School Improvement Council Member:

I am a doctoral candidate in the Educational Leadership Studies Program at West Virginia University. As part of the requirements for this degree, I am conducting a study on school improvement councils in West Virginia. The attached survey is the basis for this study, which will provide a description of school improvement councils and their activities.

I would be most appreciative if you would take the time to complete the survey, seal it in the envelope provided, and mail it to me by December 15, 1998. Your participation in this study is voluntary and you do not have to respond to every item, but the information provided will be valuable to the study.

Please rest assured that your response will remain confidential. No individually identified responses will appear in the course of this research.

Thank you in advance for taking the time to answer the questions in the survey.

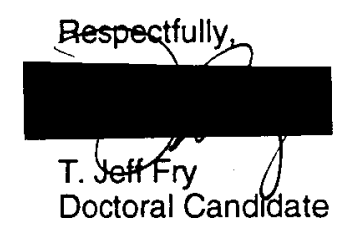

\footnotetext{
Educational Leadership Studies . Educational Psychology . Social and Cultural Foundations • Technology Education (Phone) 304 293-3049 व (FAX) 304 293-2279 a PO Box E*22 Allen Hall $\square$ Morgantown WV 26506-6122 Equal Opportunity/ Affirmai've Action Institution
} 


\section{SURVEY INSTRUMENT}

Sample Number

\section{SCHOOL IMPROVEMENT COUNCIL SURVEY}

Please respond to the following questions which describe your school and/or your role on the school improvement council. Thank you.

1. The grade levels in your school are from to and including

2. What is the size of your school based on student population? (Mark One)

Less than 200 students

Between 201 and 500 students

More than 500 students

3. What is your role on the School Improvement Council? (Mark One)

Principal

Teacher

Service Personnel

Parent
At-Large Member

At-Large Member, Business

Student

Other (List)

4. How long, including this year, have you been a member of the School Improvement Council?

Years (Please count portions of one year as one whole year)

5. How regularly do you attend School Improvement Council meetings?

I attend every meeting

I attend most meetings

I attend a few meetings

I am seldom or never at a meeting

6. Have you participated in formal training related to your responsibilities as a member of the School Improvement Council? Yes No 
7. What is the size of the school district in which your school is located? Under 2500 students Between 2501 and 6000 students Over 6000 students

The following questions are designed to find out about the work of the school improvement council in your school. Pleas respond by placing an $\mathrm{X}$ on the response that best describes your perceptions about your own school improvement council.

1. To what extent has the School Improvement Council in your school enacted programs that encourage the involvement of parents?

\begin{tabular}{|l|l|l|l|l|l|}
\hline always & regularly & occasionally & rarely & never & don't know \\
\hline
\end{tabular}

2. As a result of efforts of the School Improvement Council, how often do businesses in your community provide more time for their employees to meet with teachers?

\begin{tabular}{|c|c|c|c|c|c|}
\hline always & regularly & occasionally & rarely & never & don't know \\
\hline
\end{tabular}

3. The School Improvement Council in my school seeks advice from the business community.

\begin{tabular}{|c|c|c|c|c|c|}
\hline always & regularly & occasionally & rarely & never & don't know \\
\hline
\end{tabular}

4. The School Improvement Council in my school encourages school volunteer programs.

\begin{tabular}{|c|c|c|c|c|c|}
\hline always & regularly & occasionally & rarely & never & don't know \\
\hline
\end{tabular}


5. My school's School Improvement Council encourages the community to use school facilities for community activities.

\begin{tabular}{|c|c|c|c|c|c|}
\hline always & regularly & occasionally & rarely & never & don't know \\
\hline
\end{tabular}

6. The business members on my school's School Improvement Council actively contribute suggestions with regard to school improvement.

\begin{tabular}{|c|c|c|c|c|c|}
\hline always & regularly & occasionally & rarely & never & don't know \\
\hline
\end{tabular}

7. My School Improvement Council has requested waivers of State Board of Education policies.

\begin{tabular}{|c|c|c|c|c|c|}
\hline always & regularly & occasionally & rarely & never & don't know \\
\hline
\end{tabular}

8. My School Improvement Council has obtained waivers of State Board Policies.

\begin{tabular}{|c|c|c|c|c|c|}
\hline always & regularly & occasionally & rarely & never & don't know \\
\hline
\end{tabular}

9. My School Improvement Council has requested waivers of Local Board of Education policies.

\begin{tabular}{|c|c|c|c|c|c|}
\hline always & regularly & occasionally & rarely & never & don't know \\
\hline
\end{tabular}

10. My School Improvement Council has obtained waivers of Local Board policies.

\begin{tabular}{|c|c|c|c|c|c|}
\hline always & regularly & occasionally & rarely & never & don't know \\
\hline
\end{tabular}

11. The School Improvement Council at my school has developed a mentorship program.

Yes $\quad$ No 
12. The School Improvement Council at my school has applied for a "school of Excellence" Award.

Y Yes $\quad$ No

13. On our School Improvement Council, the leadership role is usually assumed by: (select only one)

$\begin{array}{lll}\text { Principal } & \text { Service Personnel } & \text { At-large Member } \\ \text { — Teacher } & \text { _ Parent } & \text { No One } \\ \text { Student _ Other } & \text { (Describe)__ }\end{array}$

14. Most of the ideas expressed in our School Improvement Council meetings appear to come from: (select only one)

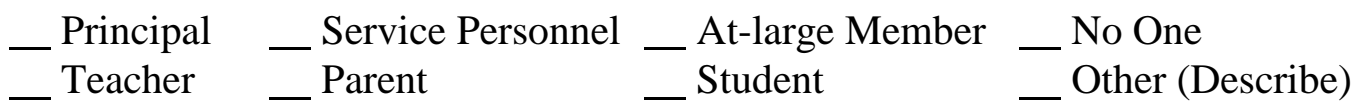

15. List up to five (5) major accomplishments of your school's School Improvement Council. Be as specific and descriptive as you can, using only the space provided.
A.
B.
C.
D.
E.

16. List what you think are the two (2) major strengths of your school's School Improvement Council. Items listed in \# 15 may be repeated if pertinent.
A.
B. 
17. List what you think are the two (2) major weaknesses of your school's School Improvement Council. (What would make your council better?)
A.
B.

The following questions are designed to determine the extent that changes have occurred in your school that may be attributed to the establishment of school improvement councils. Please place an $\mathrm{X}$ on your selected response.

18. To what extent has the operation of the school improvement council improved the quality of teacher performance in your school?

\begin{tabular}{|l|l|l|l|l|l|}
\hline significantly & very much & moderately & somewhat & $\begin{array}{c}\text { not at } \\
\text { all }\end{array}$ & don't know \\
\hline
\end{tabular}

19. To what extent has the operation of the school improvement council improved the quality of service personnel performance in your school?

\begin{tabular}{|l|l|l|l|l|l|}
\hline significantly & very much & moderately & somewhat & $\begin{array}{c}\text { not at } \\
\text { all }\end{array}$ & don't know \\
\hline
\end{tabular}

20. To what extent has the operation of the school improvement council improved the quality of student performance as measured by standardized test performance in your school?

\begin{tabular}{|l|l|l|l|c|l|}
\hline significantly & very much & moderately & somewhat & $\begin{array}{c}\text { not at } \\
\text { all }\end{array}$ & don't know \\
\hline
\end{tabular}

21. To what extent has the operation of the school improvement council increased the involvement of parents in the decision-making process at your school?

\begin{tabular}{|l|l|l|l|c|l|}
\hline significantly & very much & moderately & somewhat & $\begin{array}{c}\text { not at } \\
\text { all }\end{array}$ & don't know \\
\hline
\end{tabular}


22. To what extent has the operation of the school improvement council increased the involvement of business leaders in the decision-making process at your school?

\begin{tabular}{|l|l|l|l|l|l|}
\hline significantly & very much & moderately & somewhat & $\begin{array}{c}\text { not at } \\
\text { all }\end{array}$ & don't know \\
\hline
\end{tabular}

23. To what extent has the operation of the school improvement council increased the involvement of students in the decision-making process at your school?

\begin{tabular}{|l|l|l|l|c|c|}
\hline significantly & very much & moderately & somewhat & $\begin{array}{c}\text { not at } \\
\text { all }\end{array}$ & don't know \\
\hline
\end{tabular}

24. To what extent has the operation of the school improvement council increased the involvement of service personnel in the decision-making process at your school?

\begin{tabular}{|l|l|l|l|l|l|}
\hline significantly & very much & moderately & somewhat & $\begin{array}{c}\text { not at } \\
\text { all }\end{array}$ & don't know \\
\hline
\end{tabular}

25. To what extent has the operation of the school improvement council increased the involvement of teachers in the decision-making process at your school?

\begin{tabular}{|l|l|l|l|l|l|}
\hline significantly & very much & moderately & somewhat & $\begin{array}{c}\text { not at } \\
\text { all }\end{array}$ & don't know \\
\hline
\end{tabular}

26. Add any comments which you feel are relevant to this survey or to School Improvement Councils in general. 
APPENDIX B

NUMBER OF RESPONSES

PER SCHOOL 
NUMBER OF RESPONSES PER SCHOOL

\begin{tabular}{|c|c|}
\hline School Identification Number & Number of Responses Received \\
\hline 1.1 & 2 \\
\hline 1.2 & 6 \\
\hline 1.3 & 3 \\
\hline 1.4 & 8 \\
\hline 1.5 & 2 \\
\hline 2.1 & 10 \\
\hline 2.2 & 3 \\
\hline 2.4 & 6 \\
\hline 2.5 & 5 \\
\hline 3.1 & 4 \\
\hline 3.2 & 5 \\
\hline 3.3 & 6 \\
\hline 3.5 & 1 \\
\hline 4.1 & 1 \\
\hline 4.2 & 1 \\
\hline 4.3 & 4 \\
\hline 5.1 & 3 \\
\hline 5.3 & 4 \\
\hline 5.4 & 7 \\
\hline 5.5 & 2 \\
\hline 6.2 & 1 \\
\hline 6.3 & 2 \\
\hline 6.5 & 2 \\
\hline 7.1 & 2 \\
\hline
\end{tabular}




\begin{tabular}{|c|c|}
\hline School Identification Number & Number of Responses Received \\
\hline 8.1 & 1 \\
\hline 8.2 & 4 \\
\hline 8.3 & 7 \\
\hline 8.5 & 7 \\
\hline 9.2 & 2 \\
\hline 9.3 & 7 \\
\hline 9.4 & 2 \\
\hline 9.5 & 4 \\
\hline 9.6 & 5 \\
\hline 9.7 & 7 \\
\hline 11.3 & 4 \\
\hline 12.1 & 1 \\
\hline 12.2 & 4 \\
\hline 12.3 & 7 \\
\hline 12.4 & 6 \\
\hline 12.5 & 1 \\
\hline 13.1 & 1 \\
\hline 13.2 & 8 \\
\hline 13.3 & 4 \\
\hline 13.5 & 5 \\
\hline 14.1 & 3 \\
\hline 14.2 & 5 \\
\hline 14.3 & 3 \\
\hline 14.4 & 3 \\
\hline 14.5 & 3 \\
\hline
\end{tabular}




\begin{tabular}{|c|c|}
\hline School Identification Number & Number of Responses Received \\
\hline 15.1 & 1 \\
\hline 15.2 & 1 \\
\hline 15.3 & 3 \\
\hline 15.5 & 3 \\
\hline 16.2 & 4 \\
\hline 16.3 & 2 \\
\hline 17.1 & 5 \\
\hline 17.2 & 3 \\
\hline 17.3 & 6 \\
\hline 18.1 & 2 \\
\hline 18.2 & 5 \\
\hline 18.3 & 2 \\
\hline 18.5 & 5 \\
\hline 19.1 & 9 \\
\hline 19.2 & 6 \\
\hline 19.3 & 4 \\
\hline 19.4 & 8 \\
\hline 20.1 & 1 \\
\hline 20.2 & 2 \\
\hline 20.3 & 4 \\
\hline 20.4 & 3 \\
\hline 20.5 & 3 \\
\hline
\end{tabular}


APPENDIX C

\section{COMPARISON SUMMARIES}




\section{COMPARISON TABLES}

\section{TOTAL RESPONSE SUMMARIES PER QUESTION}

QUESTION \# 1

SIC"s Encourage Parental Involvement Programs

\begin{tabular}{|l|c|c|c|c|c|c|}
\hline Response & Always & Regularly & Occasionally & Rarely & Never & $\begin{array}{c}\text { Don't } \\
\text { Know }\end{array}$ \\
\hline 1994 & $21.6 \%$ & $38.4 \%$ & $26.1 \%$ & $8 \%$ & $2 \%$ & $4 \%$ \\
\hline 1999 & $15.4 \%$ & $49.1 \%$ & $23.4 \%$ & $7.7 \%$ & $.4 \%$ & $4 \%$ \\
\hline
\end{tabular}

\section{QUESTION \# 2}

Business Provides Time to Meet Teachers

\begin{tabular}{|l|c|c|c|c|c|c|}
\hline Response & Always & Regularly & Occasionally & Rarely & Never & $\begin{array}{c}\text { Don't } \\
\text { Know }\end{array}$ \\
\hline 1994 & $3 \%$ & $15.8 \%$ & $31 \%$ & $17.1 \%$ & $13.2 \%$ & $20 \%$ \\
\hline 1999 & $2.6 \%$ & $16.1 \%$ & $31.5 \%$ & $24.5 \%$ & $7 \%$ & $18.3 \%$ \\
\hline
\end{tabular}

\section{QUESTION \# 3}

SIC Seeks Advice From Business

\begin{tabular}{|l|c|c|c|c|c|c|}
\hline Response & Always & Regularly & Occasionally & Rarely & Never & $\begin{array}{c}\text { Don't } \\
\text { Know }\end{array}$ \\
\hline 1994 & $11 \%$ & $29.4 \%$ & $39.7 \%$ & $10.6 \%$ & $4.5 \%$ & $4.8 \%$ \\
\hline 1999 & $6.2 \%$ & $32.6 \%$ & $42.9 \%$ & $9.9 \%$ & $1.8 \%$ & $6.6 \%$ \\
\hline
\end{tabular}




\section{QUESTION \# 4}

SIC Encourages School Volunteer Programs

\begin{tabular}{|l|c|c|c|c|c|c|}
\hline Response & Always & Regularly & Occasionally & Rarely & Never & $\begin{array}{c}\text { Don't } \\
\text { Know }\end{array}$ \\
\hline 1994 & $37.4 \%$ & $38.7 \%$ & $17.1 \%$ & $3.2 \%$ & $2 \%$ & $2 \%$ \\
\hline 1999 & $35.9 \%$ & $36.3 \%$ & 17.6 & 5.9 & $.7 \%$ & $3.7 \%$ \\
\hline
\end{tabular}

\section{QUESTION \# 5}

Community Uses School Facilities

\begin{tabular}{|l|c|c|c|c|c|c|}
\hline Response & Always & Regularly & Occasionally & Rarely & Never & $\begin{array}{c}\text { Don't } \\
\text { Know }\end{array}$ \\
\hline 1994 & $23.5 \%$ & $32.9 \%$ & $22.9 \%$ & $6.8 \%$ & $6.5 \%$ & $7.4 \%$ \\
\hline 1999 & $20.9 \%$ & $38.1 \%$ & $19.4 \%$ & $12.1 \%$ & $3.3 \%$ & $6.2 \%$ \\
\hline
\end{tabular}

\section{QUESTION \# 6}

Business Contributes Suggestions To LSIC

\begin{tabular}{|l|c|c|c|c|c|c|}
\hline Response & Always & Regularly & Occasionally & Rarely & Never & $\begin{array}{c}\text { Don't } \\
\text { Know }\end{array}$ \\
\hline 1994 & $20.3 \%$ & $33.5 \%$ & $28.1 \%$ & $9 \%$ & $4.8 \%$ & $4.2 \%$ \\
\hline 1999 & $15.4 \%$ & $41.5 \%$ & $23.5 \%$ & $12.9 \%$ & $1.8 \%$ & $4.8 \%$ \\
\hline
\end{tabular}




\section{QUESTION \# 7}

SIC Requests Waivers of State Board Policies

\begin{tabular}{|l|c|c|c|c|c|c|}
\hline Response & Always & Regularly & Occasionally & Rarely & Never & $\begin{array}{c}\text { Don't } \\
\text { Know }\end{array}$ \\
\hline 1994 & $.6 \%$ & $6.5 \%$ & $15.8 \%$ & $9.7 \%$ & $42.3 \%$ & $25.2 \%$ \\
\hline 1999 & $2.6 \%$ & $5.6 \%$ & $22.2 \%$ & $10.4 \%$ & $28.5 \%$ & $30.7 \%$ \\
\hline
\end{tabular}

\section{QUESTION \# 8}

SIC Obtained Waivers of State Board Policies

\begin{tabular}{|l|c|c|c|c|c|c|}
\hline Response & Always & Regularly & Occasionally & Rarely & Never & $\begin{array}{c}\text { Don't } \\
\text { Know }\end{array}$ \\
\hline 1994 & $1 \%$ & $4.2 \%$ & $15.2 \%$ & $4.8 \%$ & $47.7 \%$ & $27.1 \%$ \\
\hline 1999 & $3 \%$ & $5.9 \%$ & $17.5 \%$ & $8.9 \%$ & $29 \%$ & $35.7 \%$ \\
\hline
\end{tabular}

\section{QUESTION \# 9}

SIC Requests Waivers of Local Board Policies

\begin{tabular}{|l|c|c|c|c|c|c|}
\hline Response & Always & Regularly & Occasionally & Rarely & Never & $\begin{array}{c}\text { Don't } \\
\text { Know }\end{array}$ \\
\hline 1994 & $.3 \%$ & $4.8 \%$ & $22.3 \%$ & $11.9 \%$ & $34.5 \%$ & $26.1 \%$ \\
\hline 1999 & $1.8 \%$ & $6.6 \%$ & $18.8 \%$ & $14 \%$ & $26.6 \%$ & $32.1 \%$ \\
\hline
\end{tabular}




\section{QUESTION \# 10}

SIC Obtained Waivers of Local Board Policies

\begin{tabular}{|l|c|c|c|c|c|c|}
\hline Response & Always & Regularly & Occasionally & Rarely & Never & $\begin{array}{c}\text { Don't } \\
\text { Know }\end{array}$ \\
\hline 1994 & $1.9 \%$ & $4.2 \%$ & $19 \%$ & $10 \%$ & $37.4 \%$ & $27.4 \%$ \\
\hline 1999 & $1.9 \%$ & $7 \%$ & $16.7 \%$ & $10.4 \%$ & $28.5 \%$ & $35.6 \%$ \\
\hline
\end{tabular}

\section{QUESTION \# 11}

SIC Developed Mentorship Programs

\begin{tabular}{|l|c|c|c|}
\hline Response & Yes & No & Don't Know \\
\hline 1994 & $16.8 \%$ & $80.3 \%$ & $2.9 \%$ \\
\hline 1999 & $23.9 \%$ & $75.7 \%$ & $.4 \%$ \\
\hline
\end{tabular}

\section{QUESTION \# 12}

SIC Applied for "School Of Excellence" Award

\begin{tabular}{|l|c|c|c|}
\hline Response & Yes & No & Don't Know \\
\hline 1994 & $17.1 \%$ & $79.7 \%$ & $3.2 \%$ \\
\hline 1999 & $35.4 \%$ & $64.6 \%$ & $0 \%$ \\
\hline
\end{tabular}




\section{QUESTION \# 13}

SIC Leadership Provided By Which Member?

\begin{tabular}{|l|c|c|c|c|c|c|c|}
\hline Response & Principal & Teacher & $\begin{array}{c}\text { Service } \\
\text { Personnel }\end{array}$ & Parent & At-Large & Student & $\begin{array}{c}\text { No } \\
\text { One }\end{array}$ \\
\hline 1994 & $62.3 \%$ & $21.9 \%$ & $0 \%$ & $5.2 \%$ & $3.9 \%$ & $0 \%$ & $.6 \%$ \\
\hline 1999 & $56.1 \%$ & $23.2 \%$ & $1.1 \%$ & $8.5 \%$ & $4.4 \%$ & $.4 \%$ & $0 \%$ \\
\hline
\end{tabular}

\section{QUESTION \# 14}

SIC Suggestions Come From Which Member?

\begin{tabular}{|l|c|c|c|c|c|c|c|}
\hline Response & Principal & Teacher & $\begin{array}{c}\text { Service } \\
\text { Personnel }\end{array}$ & Parent & $\begin{array}{c}\text { At- } \\
\text { Large }\end{array}$ & Student & $\begin{array}{c}\text { No } \\
\text { One }\end{array}$ \\
\hline 1994 & $32.3 \%$ & $21.9 \%$ & $1 \%$ & $6.5 \%$ & $7.1 \%$ & $0 \%$ & $1.9 \%$ \\
\hline 1999 & $32.2 \%$ & $24.7 \%$ & $.7 \%$ & $12 \%$ & $5.6 \%$ & $.7 \%$ & $.7 \%$ \\
\hline
\end{tabular}

\section{QUESTION \# 15}

List Five Major SIC Accomplishments at Your School

No Summary Table Used

\section{QUESTION \# 16}

List Two Major Strengths of Your SIC

No Summary Table Used 


\section{QUESTION \# 17}

\section{List Two Major Weaknesses of Your SIC}

No Summary Table Used

\section{QUESTION \# 18}

Teacher Performance Improved

\begin{tabular}{|l|c|c|c|c|c|c|}
\hline Response & Significantly & $\begin{array}{c}\text { Very } \\
\text { Much }\end{array}$ & Moderately & $\begin{array}{c}\text { Some } \\
\text { What }\end{array}$ & $\begin{array}{c}\text { Not At } \\
\text { All }\end{array}$ & $\begin{array}{c}\text { Don't } \\
\text { Know }\end{array}$ \\
\hline 1994 & $1.6 \%$ & $12.9 \%$ & $27.1 \%$ & $27.4 \%$ & $18.1 \%$ & $12.9 \%$ \\
\hline 1999 & $1.5 \%$ & $14.9 \%$ & $32.6 \%$ & $24.5 \%$ & $19.5 \%$ & $6.9 \%$ \\
\hline
\end{tabular}

\section{QUESTION \# 19}

Service Personnel Performance Improved

\begin{tabular}{|l|c|c|c|c|c|c|}
\hline Response & Significantly & $\begin{array}{c}\text { Very } \\
\text { Much }\end{array}$ & Moderately & $\begin{array}{c}\text { Some } \\
\text { What }\end{array}$ & $\begin{array}{c}\text { Not At } \\
\text { All }\end{array}$ & $\begin{array}{c}\text { Don't } \\
\text { Know }\end{array}$ \\
\hline 1994 & $1.3 \%$ & $8.4 \%$ & $23.2 \%$ & $25.8 \%$ & $26.8 \%$ & $14.5 \%$ \\
\hline 1999 & $1.1 \%$ & $8.4 \%$ & $28.9 \%$ & $23.2 \%$ & $28.1 \%$ & $10.3 \%$ \\
\hline
\end{tabular}




\section{QUESTION \# 20}

Student Performance Improved

\begin{tabular}{|l|c|c|c|c|c|c|}
\hline Response & Significantly & $\begin{array}{c}\text { Very } \\
\text { Much }\end{array}$ & Moderately & $\begin{array}{c}\text { Some } \\
\text { What }\end{array}$ & $\begin{array}{c}\text { Not At } \\
\text { All }\end{array}$ & $\begin{array}{c}\text { Don't } \\
\text { Know }\end{array}$ \\
\hline 1994 & $2.3 \%$ & $15.2 \%$ & $21 \%$ & $20.3 \%$ & $12.9 \%$ & $28.4 \%$ \\
\hline 1999 & $7.5 \%$ & $16.9 \%$ & $27.1 \%$ & $25.9 \%$ & $13.5 \%$ & $9 \%$ \\
\hline
\end{tabular}

\section{QUESTION \# 21}

Parents Involved in Decision-Making

\begin{tabular}{|c|c|c|c|c|c|c|}
\hline Response & Significantly & $\begin{array}{c}\text { Very } \\
\text { Much }\end{array}$ & Moderately & $\begin{array}{c}\text { Some } \\
\text { What }\end{array}$ & $\begin{array}{c}\text { Not At } \\
\text { All }\end{array}$ & $\begin{array}{c}\text { Don't } \\
\text { Know }\end{array}$ \\
\hline 1994 & $6.5 \%$ & $23.9 \%$ & $31.6 \%$ & $26.5 \%$ & $6.8 \%$ & $4.8 \%$ \\
\hline 1999 & $4.1 \%$ & $31.6 \%$ & $29.3 \%$ & $21.8 \%$ & $9.8 \%$ & $3.4 \%$ \\
\hline
\end{tabular}




\section{QUESTION \# 22}

Business Involved in Decision-Making

\begin{tabular}{|l|c|c|c|c|c|c|}
\hline Response & Significantly & $\begin{array}{c}\text { Very } \\
\text { Much }\end{array}$ & Moderately & $\begin{array}{c}\text { Some } \\
\text { What }\end{array}$ & $\begin{array}{c}\text { Not At } \\
\text { All }\end{array}$ & $\begin{array}{c}\text { Don't } \\
\text { Know }\end{array}$ \\
\hline 1994 & $3.9 \%$ & $19 \%$ & $27.4 \%$ & $28.1 \%$ & $12.6 \%$ & $9 \%$ \\
\hline 1999 & $4.2 \%$ & $23 \%$ & $24.9 \%$ & $29.1 \%$ & $13.2 \%$ & $5.7 \%$ \\
\hline
\end{tabular}

\section{QUESTION \# 23}

Students Involved in Decision-Making

\begin{tabular}{|l|c|c|c|c|c|c|}
\hline Response & Significantly & $\begin{array}{c}\text { Very } \\
\text { Much }\end{array}$ & Moderately & $\begin{array}{c}\text { Some } \\
\text { What }\end{array}$ & $\begin{array}{c}\text { Not At } \\
\text { All }\end{array}$ & $\begin{array}{c}\text { Don't } \\
\text { Know }\end{array}$ \\
\hline 1994 & $1.3 \%$ & $10 \%$ & $23.2 \%$ & $23.9 \%$ & $29.7 \%$ & $11.9 \%$ \\
\hline 1999 & $1.5 \%$ & $9.8 \%$ & $28.2 \%$ & $28.6 \%$ & $24.8 \%$ & $7.1 \%$ \\
\hline
\end{tabular}




\section{QUESTION \# 24}

Service Personnel Involved in Decision-Making

\begin{tabular}{|l|c|c|c|c|c|c|}
\hline Response & Significantly & $\begin{array}{c}\text { Very } \\
\text { Much }\end{array}$ & Moderately & $\begin{array}{c}\text { Some } \\
\text { What }\end{array}$ & $\begin{array}{c}\text { Not At } \\
\text { All }\end{array}$ & $\begin{array}{c}\text { Don't } \\
\text { Know }\end{array}$ \\
\hline 1994 & $2.6 \%$ & $18.4 \%$ & $25.5 \%$ & $31.9 \%$ & $10 \%$ & $11.6 \%$ \\
\hline 1999 & $2.2 \%$ & $15.7 \%$ & $30.3 \%$ & $30.7 \%$ & $10.9 \%$ & $10.1 \%$ \\
\hline
\end{tabular}

\section{QUESTION \# 25}

Teachers Involved in Decision-Making

\begin{tabular}{|l|c|c|c|c|c|c|}
\hline Response & Significantly & $\begin{array}{c}\text { Very } \\
\text { Much }\end{array}$ & Moderately & $\begin{array}{c}\text { Some } \\
\text { What }\end{array}$ & $\begin{array}{c}\text { Not At } \\
\text { All }\end{array}$ & $\begin{array}{c}\text { Don't } \\
\text { Know }\end{array}$ \\
\hline 1994 & $21.6 \%$ & $38.4 \%$ & $26.1 \%$ & $8.1 \%$ & $1.9 \%$ & $3.9 \%$ \\
\hline 1999 & $7.5 \%$ & $28.1 \%$ & $30.7 \%$ & $23.6 \%$ & $5.2 \%$ & $4.9 \%$ \\
\hline
\end{tabular}




\section{VITA}

THURMAN JEFFREY FRY

\section{PERSONAL DATA}

Home Address:

PO Box 233

Lavalette, WV 25535

Telephone:

(304) 697-0701

Business Address:

Wayne County Schools

212 North Court Street

Wayne, WV 25570

Business Telephone:

(304) 272-5116

\section{EDUCATIONAL BACKGROUND}

Ed.D., West Virginia University, Educational Leadership, 1999

M.A., Marshall University, Educational Administration, 1978

B.A., Marshall University, Elementary Education, 1977

B.A., Glenville State College, Business Administration, 1971

A.A., Glenville State College, General Business

PERMANENT CERTIFICATION, WEST VIRGINIA 
PROFESSIONAL WORK EXPERIENCE

$\underline{\text { Title }} \underline{\text { Dates }} \underline{\text { Employer }}$

Director of Research,

Planning, and Operations 1983-Present Wayne Co. Schools

Wayne, WV

Principal

1978-1983

Genoa Elementary

Genoa, WV

Teacher

1972-1983

East Lynn Elementary

East Lynn, WV

\section{PROFESSIONAL ORGANIZATIONS}

West Virginia Association of School Administrators 